UNIVERSIDADE DE SÃO PAULO

FACULDADE DE DIREITO DE RIBEIRÃO PRETO

RAFAEL SANTOS DE JESUS

AS NOVAS TECNOLOGIAS NO CONTROLE DA ADMINISTRAÇÃO PÚBLICA

RIBEIRÃO PRETO

2018 
RAFAEL SANTOS DE JESUS

\title{
AS NOVAS TECNOLOGIAS NO CONTROLE DA ADMINISTRAÇÃO PÚBLICA
}

\author{
Versão Corrigida \\ (Versão original encontra-se na Faculdade de Direito de Ribeirão Preto da Universidade de \\ São Paulo) \\ Dissertação apresentada à Faculdade de Direito de \\ Ribeirão Preto da Universidade de São Paulo para a \\ obtenção do título de Mestre em Ciências do Programa de \\ Direito. \\ Área de Concentração: Desenvolvimento no Estado \\ Democrático de Direito \\ Orientador: Prof. Dr. Raul Miguel Freitas de Oliveira
}

\section{RIBEIRÃO PRETO}


Autorizo a reprodução e divulgação total ou parcial deste trabalho, por qualquer meio convencional ou eletrônico, para fins de estudo e pesquisa, desde que citada a fonte.

Ficha catalográfica elaborada pela Biblioteca

e Seção Técnica de Informática da FDRP/USP, com os dados fornecidos pelo(a) autor(a)

\section{de Jesus, Rafael Santos}

d278n As novas tecnologias no controle da Administração Pública / Rafael Santos de Jesus; orientador Raul Miguel Freitas de Oliveira. -Ribeirão Preto, 2018. $120 \mathrm{p}$.

Dissertação (Mestrado - Programa de Pós-Graduação em Direito) -Faculdade de Direito de Ribeirão Preto, Universidade de São Paulo, 2018.

1. CONTROLE DA ADMINISTRAÇÃO PÚBLICA. 2. SOCIEDADE EM REDE. 3. NOVAS TECNOLOGIAS. 4. TICS. 5. REDE DE CONTROLE. I. de Oliveira, Raul Miguel Freitas, orient. II. Título 

Nome: Rafael Santos de Jesus

Título: As Novas Tecnologias no Controle da Administração Pública

Dissertação apresentada ao Programa de Pós-

Graduação da Faculdade de Direito de Ribeirão

Preto da Universidade de São Paulo como requisito parcial para a obtenção do título de Mestre em Ciências.

\section{Banca Examinadora}

$\operatorname{Prof}(\mathrm{a}) . \operatorname{Dr}(\mathrm{a})$ :

Julgamento:

$\operatorname{Prof}(\mathrm{a}) . \operatorname{Dr}(\mathrm{a})$ :

Julgamento:

$\operatorname{Prof}(a) . \operatorname{Dr}(a)$ :

Julgamento:

$\operatorname{Prof}(a) . \operatorname{Dr}(a)$ :

Julgamento:
Instituição:

Assinatura:

Instituição:

Assinatura:

Instituição:

Assinatura:

Instituição:

Assinatura: 

Dedicado aos meus pais. 



\section{AGRADECIMENTOS}

De início, agradeço aos meus pais, Adalberto da Silva de Jesus e Liliana Aparecida dos Santos de Jesus, que propiciaram todas as condições que culminaram neste ponto. Desde os primeiros passos estiveram presentes em todos os momentos importantes, nas vitórias ou adversidades. Essencial nestas etapas mais recentes, deixo meu muito obrigado ao Professor Doutor Raul Miguel Freitas de Oliveira, primeiro por ter me aceitado e acreditado no projeto. Ademais, agradeço por tantos conselhos e orientações, válidos para muito além da vida acadêmico, que me permitiram chegar até aqui e sonhar ainda mais.

Gostaria também de homenagear todos os demais professores e colegas que estiveram presentes nessa jornada, cada qual com sua importante contribuição. Especial menção merece a minha amiga Julia Magalhães Jeuken, que desde a graduação me auxiliou em todos os momentos, e meu amigo Marcelo Bidoia dos Santos, por compartilhar seus conhecimentos no campo.

Registro também meu agradecimento à Faculdade de Direito de Ribeirão Preto da Universidade de São Paulo, instituição de importância única em minha formação, e da qual tenho orgulho de ter feito parte. Desde 2011 são muitos momentos marcantes e aprendizados que definem uma trajetória.

Por fim, agradeço acima de tudo a Deus e ao Senhor, pois do contrário nada seria possível. 

"Os que se encantam com a prática sem a ciência são como os timoneiros que entram no navio sem timão nem bússola, nunca tendo certeza do seu destino".

(Leonardo da Vinci) 



\section{RESUMO}

JESUS, Rafael Santos de. Novas tecnologias no controle da Administração Pública. 2018. Dissertação (Mestrado em Direito) - Faculdade de Direito de Ribeirão Preto, Universidade de São Paulo, Ribeirão Preto, 2018.

As novas tecnologias moldaram a sociedade atual e são fatores chave no aprimoramento do controle da Administração Pública. Com base em uma linha jurídico-sociológica, a análise da evolução do próprio Estado demonstra a elevação da função do controle. Assim, o estudo considera o conceito e possibilidades de abrangência do termo dentro desse cenário, bem como suas classificações mais relevantes para os objetivos propostos. Com o panorama do sistema de controle no país são identificados os dilemas atuais que obstam o controle no nível que dele se espera. Como elo com as novas tecnologias, a obra de Manuel Castells é referencial por apresentar os impactos que conduziram à sociedade em rede. A morfologia das redes já foi identificada na prática como forma de organização social, e não há óbice para sua implementação no controle da Administração Pública, com o emprego de ferramentas tecnológicas. As deduções são aplicadas à Plataforma de Acompanhamento de Licitações Públicas (PALP), iniciativa que simboliza o potencial transformador das novas tecnologias no controle da Administração Pública.

Palavras-chave: Controle da Administração Pública. Sociedade em Rede. Novas Tecnologias. TICs. Rede de controle. 



\begin{abstract}
JESUS, Rafael Santos de. New technologies and control of public administration. 2018. Dissertação (Mestrado em Direito) - Faculdade de Direito de Ribeirão Preto, Universidade de São Paulo, Ribeirão Preto, 2018.

The new technologies have shaped the current society and are key factors in order to improve the control of Public Administration. Based on a juridical-sociological study, the analysis of the evolution of the State itself demonstrates the growth of the control function. Thus, this study considers the concept and scope of the term control, as well as its most relevant classifications, considering the proposed objectives. Taking into account the situation of control system in the country, the current dilemmas that obstruct the control at the optimum level are identified. As a link with the new technologies, the work of Manuel Castells is referential for presenting the impacts that led to the network society. The morphology of the networks has already been identified as a form of social organization, and there is no obstacle to its implementation in the control of the Public Administration, with the use of technological tools. The results are applied to the Plataforma de Acompanhamento de Licitações Públicas (PALP), an initiative that symbolizes the transformative potential of new technologies in the control of Public Administration.
\end{abstract}

Keywords: Control of Public Administration. Network Society. New technologies. TICs. Control network. 



\section{SUMÁRIO}

INTRODUÇÃO.....................................................................................................................13

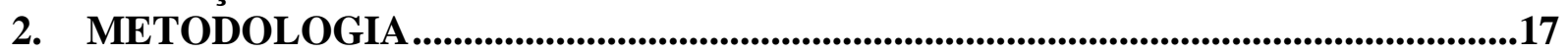

2.1 Notas preliminares e justificativas................................................................................................ 17

2.2 Marcos teóricos ......................................................................................................... 17

2.3 Limites e opções metodológicas .............................................................................................. 19

2.4 Procedimentos e dados........................................................................................................... 19

2.5 Objetivos ............................................................................................................................... 20

3. ESTADO E CONTROLE....................................................................................................23

3.1 Evoluções do Estado e controle............................................................................................... 23

3.1.1 Funções Administrativas de Fayol, Administração Pública e Direito

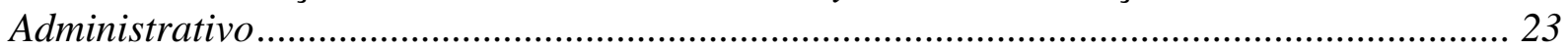

3.1.2 Desenvolvimenton histórico do Estado ............................................................. 25

3.1.3 Ampliação das Funções do Estado e a Reforma Gerencial no Brasil ................... 29

3.2 Conceitos, elementos e classificações do controle............................................................... 33

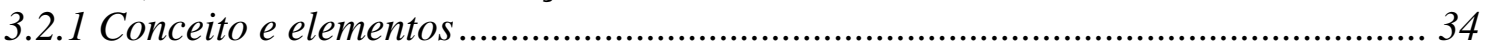

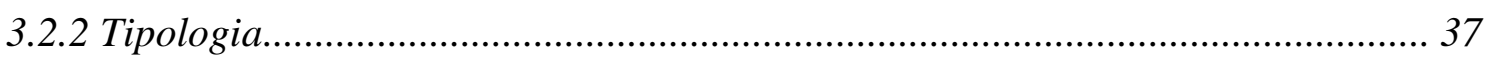

3.2.2.1 Quanto ao aspecto subjetivo do controle …………………………………..... 37

3.2.2.2 Quanto ao objeto do controle ......................................................................... 40

3.2.2.3 Quanto ao momento do controle ..................................................................... 42

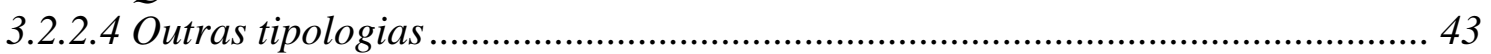

4 O CONTROLE NO BRASIL .............................................................................47

4.1 Sistema de controle interno ............................................................................................. 47

4.1.1 Autocontrole, controle hierárquico e tutela administrativa .................................. 51

4.1.2 Auditoria, Controladoria, Ouvidoria e Correição .............................................. 54

4.1.3 Lei Anticorrupção e controle interno ………………………………………........ 55

4.2 Controle Legislativo, com auxílio do Tribunal de Contas................................................... 57

4.3 Controle Judicial ..................................................................................................................... 59

4.4 Controle pelo Ministério Público............................................................................................. 62

4.5 Controle Social ................................................................................................................................ 63

4.6 Limites e impasses....................................................................................................................66

4.6.1 Desequilíbrio, duplicidade e sopreposição de trabalhos ........................................ 66

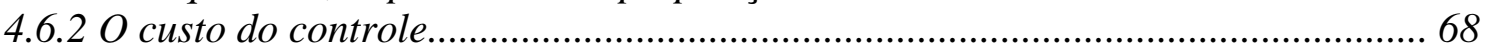

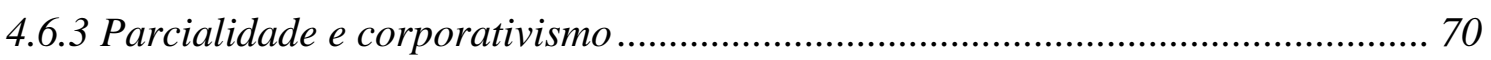

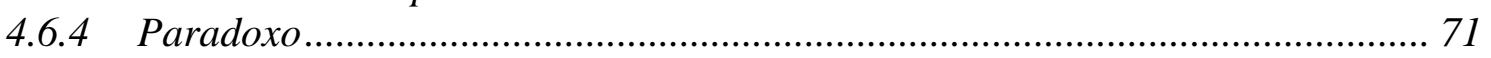

5. AS NOVAS TECNOLOGIAS NA ERA DA INFORMAÇÃO ......................................75

5.1 Conceitos essenciais.................................................................................................................... 75

5.2 Evolução ...................................................................................................................................... 78

5.3 Tecnologia e sociedade: a dinâmica das redes para Castells ............................................ 81

$5.4 \mathrm{O}$ uso da Internet na atividade política.............................................................................. 84

5.5 Perspectivas futuras - a ciberdemocracia de Pierre Levy ............................................... 87

6. INTERAÇÕES DOS CONTROLES E NOVAS TECNOLOGIAS ..................................91

6.1 Controle sistêmico ou rede de controle? ............................................................................... 91

6.2 Novas tecnologias e redes de controle .................................................................................... 93

6.3 Benefícios das novas tecnologias no controle da Administração Pública .................... 96

6.4 Análise da Plataforma de Acompanhamento de Licitações Públicas............................. 98

7. CONCLUSÕES ..............................................................................................................105

REFERÊNCIAS BIBLIOGRÁFICAS .......................................................................111 


\section{INTRODUÇÃO}

O tema do controle da Administração Pública ganhou muito espaço nos debates do cenário jurídico e político dos últimos tempos devido a seu caráter essencial à democracia e ao regime republicano (RIBEIRO; BLIACHERIENE; SANTANA, 2016, p. 25). A Declaração dos Direitos do Homem e do Cidadão de 1789 já possuía, em seu art. 15º seguinte dizer: "[a] sociedade tem o direito de pedir conta, a todo agente público, quanto à sua administração". Ainda que genericamente, e sem ter em mente a palavra controle, o preceito conceitua bem o termo.

É preciso salientar que o controle não é restrito à Administração Pública, embora existam particularidades que serão expostas em momento posterior do trabalho, e foi a ciência da Administração em âmbito privado que primeiro estudou profundamente o controle. Henri Fayol (1989, p. 130), no início do século passado, trouxe o seguinte conceito:

Numa empresa, o controle consiste em verificar se tudo corre de acordo com o programa adotado, as ordens dadas e os princípios admitidos.

Com o incremento do Estado e o aumento de seus deveres, o estudo da Administração Pública ganhou força e as funções administrativas privadas foram incorporadas no setor público. O campo de estudo que se encarregou desta tarefa no âmbito jurídico foi o Direito Administrativo.

Não raro, estudiosos de outras áreas, como a gestão púbica, utilizam conceitos de tradicionais administrativistas. Nesse sentido, Maria Sylvia Zanella Di Pietro define o controle da Administração Pública "como o poder de fiscalização e correção que sobre ela exercem os órgãos dos Poderes Judiciário, Legislativo e Executivo, com o objetivo de garantir a conformidade de sua atuação com os princípios que lhe são impostos pelo ordenamento jurídico" (DI PIETRO, 2012, p. 792).

Para citar outro exemplo na mesma linha, segundo denominação dada por José dos Santos Carvalho Filho, tem-se por controle da Administração Pública “o conjunto de mecanismos jurídicos e administrativos por meio dos quais se exerce o poder de fiscalização e revisão da atividade administrativa em qualquer das esferas de Poder" (CARVALHO FILHO, 2013, p. 941). 
Essas e outras definições não divergem muito em seus aspectos essenciais, de modo que o controle é fortemente ligado à atividade de fiscalização e correção dos atos administrativos, garantindo que estejam de acordo com o planejamento estatal e/ou ordenamento jurídico aplicável.

Em análise individual desses termos, a fiscalização consiste na vigilância permanente da atuação dos órgãos e agentes públicos empenhados na atividade administrativa (PEDREIRA, 2013, p. 1082). O mito do anel de Giges, presente no Livro II da República de Platão, elucida muito bem a importância da fiscalização (1999, p. 43-44). Segundo a lenda, Lídio era um pastor a serviço do rei, que em meio a uma tempestade encontrou uma cratera misteriosa. Curioso, explorou o local onde encontrou um homem morto, que portava um belo anel de ouro. Então pegou para si o anel e fugiu do local. Posteriormente, em reunião com demais pastores, Lídio acidentalmente girou o engaste do anel e percebeu que ficou invisível para os demais. Ao retornar o anel para a posição original, voltava a ficar visível. Impressionado com o poder do objeto, repetiu a experiência e confirmou que a habilidade funcionava de fato. E após seguiu ao palácio, onde matou o rei e apoderou-se do trono.

O que se pretende passar com a história é que não há diferença entre um homem justo ou injusto em posse de um anel como este. O poder e a certeza de impunidade fazem com que a maioria dos indivíduos não seja suficientemente forte para se manter íntegro. Daí a necessidade premente de fiscalização.

O segundo conceito que costuma compor a noção de controle é a correção, que se configura pelo poder de corrigir as condutas administrativas (PEDREIRA, 2013, p. 1082). A revisão é o remédio que possui a atividade de controle para atingimento de seus fins, sob pena de total ineficácia e compactuação com o distanciamento do padrão desejados ${ }^{1}$.

A sistematização dogmática das formas tradicionais de controle da Administração Pública é feita pela doutrina administrativista, respondendo aos embates e problemas teóricos que envolvem o tema. Contudo, conforme o controle ganha controle ganha força em decorrência de desmandos estatais, ao mesmo tempo é colocado em xeque para ver como é possível evoluir para acompanhar a sofisticação da atuação do Estado.

\footnotetext{
${ }^{1}$ Contudo, conceituar a atividade de controle através da correção pode levar ao esvaziamento das atividades de controle, como bem assevera Odete Medauar (2014, p.31-32). Em resumo, somente seria considerada atividade de controle aquela que suscita medida proposta pelo agente controlador? A reflexão fez com que a autora trouxesse dois sentidos ao termo controle, que serão expostos no item 3.2.1.
} 
Nesse sentido, Thiago Marrara alerta pela necessidade e atualidade das discussões sobre o controle:

\begin{abstract}
Nunca antes na história desse país se miraram tantos holofotes aos controles do Estado e ao exercício das funções públicas. [...] Controles existem e não há quem negue sua essencialidade. [...] Não se trata de inventar novas técnicas ou instituições de controle, mas sim de aprimorá-las, de fazê-las funcionar, de impedir que a falência ou a inoperância de algumas delas não comprometam a eficiência de outras. (2016, p. 45)
\end{abstract}

Ainda nesse contexto, é preciso dizer que "desde a promulgação da Constituição de 1988 o Brasil vivencia um movimento de ampliação do controle da Administração Pública" (MARQUES NETO; PALMA, 2017, p. 21), o que justifica a relevância do estudo. O tema ganha contornos especiais quando se leva em consideração o já citado difícil momento atual, com grandes esquemas de corrupção sendo descobertos e desconfiança generalizada com a classe política. O descontrole administrativo impõe novos desafios, e talvez as novas tecnologias possam conduzir soluções.

As Tecnologias da Informação e Comunicação (TICs), dentro das quais é incluído o "conjunto convergente de tecnologias em microeletrônica, computação (software e hardware), telecomunicações/radiodifusão, e optoeletrônica (CASTELLS, 2016, p. 87)", representam um ativo essencial a muitas organizações e remodelou o mundo neste século. Contudo, seu uso pela Administração Pública no Brasil ainda está em estágio inicial.

Manuel Castells explica muito bem que a tecnologia não determina a sociedade, que não é capaz de descrever, sozinha, o percurso da transformação tecnológica. São muitas variáveis que, apesar de alguns fatores de indução, possuem resultado incerto (2016, p. 64). As TICs, entretanto, desde seu processo de evolução até se tornarem realidade, reconstruíram as bases de relação entre agentes e organismos - privados ou públicos - culminando em um novo modo de desenvolvimento (2016, p. 61 e 88).

E mesmo com experiências práticas de aplicação de tecnologias em diversos campos, é interessante criar uma estrutura teórica que analise o surgimento desse movimento e o encaixe no objeto de estudo. O tema é multifacetado e engloba diversas áreas do conhecimento, o que torna mais intricada e relevante a proposta.

No cenário atual, com a formação de redes e alta influência de novas tecnologias, o Estado precisa atualizar-se com novos conceitos, e, sobretudo, ser capaz de lidar com 
demandas inéditas. Já existem recursos materiais e estratégicos para empregar as novas tecnologias no controle da administração, aprimorando as formas atuais e sua inter-relação, e é este o foco da pesquisa. 


\section{METODOLOGIA}

\subsection{Notas preliminares e justificativas}

Neste capítulo, serão apresentadas as bases metodológicas da pesquisa realizada, garantindo parâmetros para o estudo. Em breve síntese, será exposto o "problema" que motivou a pesquisa e a hipótese decorrente.

A imprescindibilidade do Controle está ligada à própria essência do Estado de Direito, quando o poder político é condicionado ao ordenamento jurídico. O seguinte trecho sintetiza esse caráter de essencialidade:

Não se pode conceber a Administração Pública sem controles. Aliás, o descontrole administrativo sempre foi causa de descalabros. A democracia e o regime republicano exigem controles. Controle significa transparência. Significa zelo. Significa segurança para os cidadãos diante dos atos administrativos. (RIBEIRO; BLIACHERIENE; SANTANA, 2016, p. 25)

O debate sobre as formas de melhorar o funcionamento do controle sobre a Administração Pública é aquecido em momentos de crises que envolvem a malversação de recursos públicos. Em face das limitações atuais, indaga-se se as novas tecnologias são capazes de trazer soluções inovadoras no campo do controle da Administração Pública. Deste modo, a contribuição deste estudo será investigar as Tecnologias da Informação e Comunicação (TICs) e sua lógica na aplicação dos meios de controle atuais como forma de aperfeiçoá-los.

A expressão "novas tecnologias" é utilizada em referência às mudanças e inovações ocorridas no campo da eletrônica, informática e telecomunicações desde o final do século passado. Em especial, sobressaem as Tecnologias da Informação e Comunicação, que certamente revolucionaram todos os aspectos da sociedade neste século (CASTELLS, 2016) e que têm potencial ainda inexplorado em alguns campos, tal como o deste estudo.

\subsection{Marcos teóricos}

A questão do marco teórico de uma pesquisa é muito bem colocada por Gustin e Dias (2015, p. 34). Em síntese, explicam que o marco teórico balizará o caminho da pesquisa, sendo uma ideia que será um filtro na condução dos estudos para as soluções prentendidas para o problema levantado. É, portanto, fundamento do problema, hipótese e referencial para controle do estudo. 
Interessante é assertiva das autoras de que o marco teórico é uma afirmação específica de um teórico que guiará o olhar do pesquisador (2015, p. 35), não se confundindo com a totalidade da obra deste teórico. Contudo, caso a ideia desejada fundamente a produção como um todo, ela pode sim ser base de análise e interpretação para o estudo proposto:

Pode-se, também, entender como marco teórico, a concepção que fundamenta uma ou toda obra de determinado autor. Mas não se está referindo à obra como um todo. Essa, quase sempre, é formada de um conjunto heterogêneo de argumentações e de explicações. Refere-se, assim, ao fundamento teórico de toda produção do autor ou de uma de suas obras. (2015, p. 35)

Contextualizando para o objeto desta pesquisa, importante notar que o estudo precisará de conceitos e reflexões estranhas ao Direito, em especial quanto ao assunto das novas tecnologias e suas influências. Será de destaque a posição de Manuel Castells, sociólogo espanhol nascido em 1942, cuja vasta obra aborda as transformações sociais, econômicas, políticas e culturais ocorridas na nova era da informação. Em sua trilogia "A Era da Informação", e em especial no volume "A Sociedade em Rede", são postos diversos conceitos e reflexões que serão retomados oportunamente na pesquisa, como a noção da morfologia das redes.

Mas dessa obra se extrairá, como marco teórico, os impactos das novas tecnologias na sociedade no capitalismo informacional, que permeia toda obra e é sintetizada no seguinte pensamento:

Uma revolução tecnológica concentrada nas tecnologias da informação começou a remodelar a base material da sociedade em ritmo acelerado. Economias por todo o mundo passaram a manter interdependência global, apresentando uma nova forma de relação entre economia, o Estado e a sociedade em um sistema de geometria variável. (2016, p. 61)

Evandro Martins Guerra possui suposição interessante sobre a integração do controle interno, externo e social, como forma de superação de falhas observadas na atuação isolada de cada uma das formas. O Controle sistêmico é sintetizado no seguinte trecho:

A forma sistêmica de controle exige que todos os elementos componentes estejam organizados logicamente, interligados pelo ordenamento jurídico mediante dispositivos constitucionais e legais, de maneira a facilitar o desencadeamento das atividades fiscalizatórias e corretivas. As partes do sistema, quer dizer, os sub-sistemas (social, interno e externo) devem se inter-relacionar visando ao funcionamento da estrutura, combinando meios e procedimentos que culminem na produção de certos resultados (2008, p. 10). 
Com base neste conceito e dentro da hipótese que se levanta, será feita a comparação com a proposta de rede de Castells para ver qual melhor se adequa ao uso das novas tecnologias, e assim possibilitar a criação desse espaço necessário para articulação dos controles, evitando sua sobreposição.

\subsection{Limites e opções metodológicas}

Neste estudo não se pretende contemplar todas as possíveis tipologias de controle, nem mesmo criar novas e diferentes classificações. Para tanto, existem obras dedicadas ao assunto $^{2}$. Inevitavelmente este estudo abordará sim o assunto e passará por algumas das classificações que sejam necessárias para compreensão do tema, mas sem fugir do escopo do trabalho.

E pelo termo Administração Pública deverá ser entendida tanto a Administração Direta e Administração Indireta, especialmente para fins da tipologia quanto a posição do órgão controlador em relação ao controlado. Isso é importante até mesmo porque maiores dilações sobre o tema fogem aos objetivos desta pesquisa. Porém, quando necessário, as devidas diferenciações serão feitas.

Como nota, a amplitude temática do estudo precisa ser justificada. O termo “Administração Pública" é muito amplo e poderia se sugerir uma limitação ao aspecto do controle em, por exemplo, obras e contratações públicas. Porém, como o tema é recente e carece de mais estudos, restringir a uma das funções ou atividades da Administração poderia deixar de fora do estudo iniciativas relevantes com o bom uso das novas tecnologias. Portanto, neste momento é mais interessante manter o escopo amplo e criar condições de construir uma base teórica sólida para posteriores progressões.

\subsection{Procedimentos e dados}

Para manter a unidade metodológica, a classificação adotada neste ponto também será a aquelas promovida por Gustin e Dias (2015, p. 22). O estudo que está sendo conduzido está dentro da vertente jurídico-sociológica, que possui como característica compreender o fenômeno estudado dentro de ambiente social mais amplo. Preocupa-se, portanto, com as relações estabelecidas com os demais campos e considera a forte relação entre Direito e sociedade.

\footnotetext{
${ }^{2}$ Para uma noção ampla e pormenorizada das classificações do Controle consultar o capítulo 3 da obra Controle da Administração Pública de Odete Medauar (2014)
} 
A pesquisa segue o tipo metodológico jurídico-interpretativo, por meio da análise do controle da Administração e sua decomposição em vários aspectos, até mesmo verificando o comportamento das formas de controle em um ambiente informacional. A pesquisa não deixa de ser também jurídico-propositiva, pois mesmo que não tenha a pretensão de sugerir alterações legislativas, no estudo se busca modo de aprimorar o Controle da Administração.

Sobre o raciocínio utilizado, embora haja a expectativa de análise de experiências concretas, onde o raciocínio indutivo seria utilizado na tentativa de obter generalizações, haverá predominância da lógica dedutiva.

A pesquisa é de natureza teórica, focada em revisão bibliográfica e, por conseguinte a abordagem será majoritariamente secundária, ressalvados momentos em que a análise de exemplos concretos permita a obtenção de dados primários. Quanto às fontes, esta pesquisa não utilizará apenas fontes diretas de produção de conhecimento jurídico, mas também fontes indiretas. A despeito de obras de Direito Administrativo serem parte fundamental na revisão bibliográfica do trabalho, a colaboração de teóricos da Administração e da Sociologia será essencial.

Em linhas gerais, a perspectiva de estudo será de natureza qualitativa, através de pesquisa bibliográfica em obras nacionais e estrangeiras de referência nos temas abordados, além de sítios eletrônicos especializados ou oficiais, que possam ser fonte de dados ou informações confiáveis. Apesar de a pesquisa ser majoritariamente teórica, assentada em obras e estudos acadêmicos, mas que será enriquecida por analise de experiência prática, expandindo sua validade.

\subsection{Objetivos}

\section{Objetivo geral}

Levantar e interpretar os desafios do Controle da Administração Pública na Era da Informação e contribuir com modo de aperfeiçoá-lo com o uso das novas tecnologias.

\section{Objetivos específicos}

Para concretude do objetivo geral, as análises séries serão feitas e conduzidas de modo que cada uma delas levará a um fechamento, que serão os objetivos específicos:

- Estabelecer a evolução das noções de controle, seus elementos e classificações essenciais. 
- Contextualizar o cenário do controle no ordenamento pátrio e indagar sobre suas limitações práticas atuais.

- Analisar a nova configuração social após o advento das novas tecnologias e suas influências.

- Identificar formas de articulação entre os controles e uso das TICs como forma de aprimorá-los.

- Verificar as hipóteses lançadas de acordo com o caso da Plataforma de Acompanhamento de Licitações Públicas (PALP). 


\section{ESTADO E CONTROLE}

O presente capítulo tem como meta um exame do conceito de controle, sua abrangência e uso, em especial dentro do Direito Administrativo. Portanto, inicia-se com uma perspectiva histórica para entender a situação atual das atividades de controle, para assim analisar suas limitações.

\subsection{Evoluções do Estado e controle}

Conforme já foi mencionado, a Declaração dos Direitos do Homem e do Cidadão de 1789 já possuía, em seu art. 15º o seguinte dizer: "[a] sociedade tem o direito de pedir conta, a todo agente público, quanto à sua administração". O dispositivo exprime a noção de controle na Administração Pública, embora o termo não tenha sido explicitamente usado.

Não foi o documento que inaugurou essa noção. Mesmo no Brasil, funções relacionadas ao controle já eram exercidas no período colonial, mas que foram acentuadas com a vinda da Corte portuguesa para o país (BALBE, 2016, p. 39). Porém, o controle da Administração Pública não encontrava com a devida sistematização.

A importância e o destaque dado à Declaração, presente em textos que tratam do controle, reside na antiga percepção do status da prestação de contas como um direito do cidadão em face do Estado. Apesar do recente aumento pelo interesse na área e atualidade do tema, muito se passou desde 1789 até a construção atual do controle, tanto no desenvolvimento do Estado e suas atividades, como nas ciências sociais dedicadas ao seu estudo, conforme se passa a analisar.

\subsubsection{Funções Administrativas de Fayol, Administração Pública e Direito Administrativo}

Henri Fayol foi um engenheiro francês e idealizador da Teoria Clássica da administração, no início do Século XX. Sua obra Administration Industrielle et Générale Prévoyance, Organisation, Commandement, Coordination, Contrôle, de 1916, foi de grande valia e serviu como ponto de partida, em paralelo com os estudos de Frederick Taylor, para a ciência da administração (CHIAVENATO, 2003, p. 48).

Para o autor as empresas possuem seis diferentes funções, das quais no âmbito da administração sobressai a função administrativa, que deve integrar a cúpula das demais 
funções - técnicas, comerciais, financeiras, contábeis e de segurança (CHIAVENATO, 2003, p. 80$)^{3}$.

A função administrativa, de gerenciamento da empresa, foi decomposta em cinco, que na verdade definem o ato de administrar para Fayol: planejamento, organização, comando, coordenação e controle (FAYOL, 1989). Especificamente sobre o controle, o autor, no início do século passado, trouxe o seguinte conceito: "[n]uma empresa, o controle consiste em verificar se tudo corre de acordo com o programa adotado, as ordens dadas e os princípios admitidos" (1989, p. 130).

Portanto o controle não é restrito à Administração Pública, mesmo que haja particularidades quando esse seja exercido sobre o Estado, e as experiências Ciência da Administração em âmbito privado auxiliam no entendimento do setor público, o que deve ocorrer sobre a atividade de controlar.

Nesse campo de proximidades e diferenças, Matheus Carvalho muito bem explica a diferença entre o Direito Administrativo e a Ciência da Administração, sendo proveitosa a transcrição:

A Ciência da Administração é definida como estudo de técnicas e estratégias para melhor planejar, executar e organizar a gestão governamental, definindo técnicas de gestão. Trata-se de ciência social que, inclusive, está subordinada aos princípios e regras definidos no Direito Administrativo.

Por sua vez, o Direito Administrativo é ramo jurídico e, como tal, se dedica aos estudos de regras e normas, sendo caracterizado como ciência normativa, impositiva que define os limites dentro dos quais a gestão pública - estudada pela ciência da administração - pode ser executada. (2017, p. 41)

Dentro da Ciência da Administração, a Administração Pública ${ }^{4}$ é a parte desta ciência social que se ocupa das práticas voltadas à administração dos bens e interesses coletivos. Desse modo, em que pesem as variadas conceituações (SANTOS, 2014, p. 43) a diferença principal reside na titularidade daquilo que se administra, com as consequências inerentes derivadas da lei.

\footnotetext{
3 As noções de Fayol já foram ultrapassadas, mas sua importância é grande por terem persistido por várias décadas e inspirados muitos estudos. Ainda assim, o que se tem hoje, não difere tanto do que foi sistematizado por Fayol (CHIAVENATO, 2003, p. 80-81)

${ }^{4}$ Como esclarecimento, o termo quando grafado com letras minúsculas (administração pública), indica a própria função administrativa do Estado, ao lado das funções legislativa e jurisdicional, sendo que a função administrativa está presente em todos os poderes, mesmo que usualmente associada ao Poder Executivo. Já quando são empregadas letras maiúsculas (Administração Pública), a conotação é subjetiva, indicando os órgãos e pessoas munidos dessa função administrativa (ALMEIDA; CARVALHO FILHO, 2014, p. 30)
} 


\title{
3.1.2 Desenvolvimento histórico do Estado
}

Foge aos objetivos do presente trabalho explorar de forma exaustiva a evolução do Estado desde as suas origens até o momento atual, já que existem obras mais completas sobre o assunto $^{5}$, e a digressão seria pouco proveitosa aos parâmetros aqui analisados. Contudo, na linha proposta de estudar o controle dentro da ciência da Administração, estabelecer um paralelo com o desenvolvimento do Estado e da Administração Pública, em especial no último século, é importante.

Com isso, sem ignorar todo o movimento antecedente, o ponto de partida estabelecido é o Estado Liberal, ou segundo Paulo Bonavides, Estado constitucional da separação de poderes, que teve início após a Revolução Francesa e Revolução de Independência Americana (BONAVIDES, 2012, p. 41). A característica distintiva do modelo foi a primazia da liberdade e, consequentemente, dos direitos civis e políticos, hoje configurados como direitos fundamentais de primeira geração (BONAVIDES, 2012, p. 43). O Estado constitucional como superação do Estado absoluto deixa assente tais atributos. Nas palavras de Pietro de Jesús Lora Alarcón:

\begin{abstract}
O Estado absoluto é considerado pela doutrina como o anti-modelo contra o qual se erguem a teoria e a construção política do Estado de Direito. Correntemente se estabelece uma distinção entre duas fases nesse modelo de Estado: a fase do Estado absolutista patrimonial, na qual o Estado é considerado um bem patrimonial do Príncipe, e a fase do Estado absolutista de Polícia, que teve seu apogeu no séc. XVIII, na qual o Príncipe assume plenamente a tarefa de prover a felicidade e o bem dos súditos e em que o anterior fundamento divino do poder é substituído por um fundamento racional. (2011, p. 97)
\end{abstract}

Assim, de modo gradual, o foco do Estado passou aos indivíduos, não sendo mais possível a estabilidade das relações depender exclusivamente da vontade do soberano. Para tanto, o poder deixa de ser pessoal e começa a emanar de leis, o que já permite a atividade de controle diante de um padrão. Esta é a base da conversão do Estado absoluto ao Estado constitucional, com suas posteriores mudanças.

O movimento não foi linear ou marcado com rupturas nítidas de padrões. Assim também não foram os próximos movimentos a seguir expostos, sendo que as divisões são

\footnotetext{
${ }^{5}$ Conferir, por exemplo: BONAVIDES, Paulo. Teoria Geral do Estado. 9. ed. São Paulo: Malheiros, 2012. ALARCÓN, Pietro de Jesús Lora. Ciência política, Estado e direito público: uma introdução ao direito público de contemporaneidade. São Paulo: Verbatim, 2011. Recomenda-se ainda a dissertação "Do Estado Virtual ao Estado Penal: transformações no Estado do Bem-Estar Social na Era da Informação (SANTOS, p. 2017), que trabalha de forma profunda o tema.
} 
feitas posteriormente, para fins de categorização e estudo. Não há uma ruptura temporal clara, o processo é de metamorfose e evolução, com transformações sociais e advento de novos direitos fundamentais que implicaram em novas formas de organização estatal. (BONAVIDES, 2012, p. 43).

Nessa linha, sucedeu-se então o Estado Social de Direito. O incremento da indústria, da massa de trabalhadores e a consolidação do capitalismo industrial, possibilitados pelo Estado Liberal, fizeram surgir na sociedade novos tipos de demandas ligadas à desigualdade nas relações. A falta de concretude de direitos que passaram a ser vistos como básicos alterou a dinâmica das interações:

Já o novo Estado constitucional, sucessor daquele, é conspicuamente marcado de preocupações distintas, volvidas, agora, menos para a liberdade do que para a justiça, porque a liberdade já se tinha por adquirida e positivada nos ordenamentos constitucionais, ao passo que a justiça, como anseio e valor social superior, estava ainda longe de alcançar o mesmo grau de inserção, positividade e concreção. (BONAVIDES, 2012, p. 48)

Para fins de contextualização, o progresso analisado se operou no final do século XIX até o período após II Guerra Mundial, fase em que se destaca como substrato em campo prático o capitalismo concorrencial e a concentração de renda, com explosão da população urbana e classe trabalhadora, sem o corresponde incremento de participação nas decisões estatais. A luta dos trabalhadores intensificou o viés político-institucional à medida que o Estado "neutro" os colocava em posição de desigualdade material, em interesse de estratos dominantes (ALARCÓN, 2011, p. 100-101). Até mesmo no aspecto formal e normativo, as dificuldades para o exercício do direito de greve e organização desmistificam o Estado Liberal. José Afonso da Silva leciona na mesma linha:

O individualismo e o abstencionismo ou neutralismo do Estado liberal provocaram imensas injustiças, e os movimentos sociais do século passado e deste especialmente, desvelando a insuficiência das liberdades burguesas, permitiram que se tivesse consciência da necessidade da justiça social. (SILVA, 2005, p.115)

Em conjunto, no campo doutrinário ganharam força os ideais socialistas capitaneados pelo Socialismo Utópico, que almejava uma reforma social como superação natural e pacífica do capitalismo, e pelo Socialismo Científico (Marx e Engels como expoentes), distinto por estabelecer um método diferente para atingir o fim semelhante, isto é, a luta de classes, 
apropriação coletiva dos meios de produção e final extinção do próprio Estado (BONAVIDES, 2012, p. 49).

Destaca-se também a criação do Partido Operário Socialdemocrata Alemão e o Labour Party na Inglaterra, sendo que o primeiro foi decisivo na luta pelo voto universal no contexto alemão (HOBSBAWN, 2014, p. 176-181). Embora tenha sido feita essa divisão, a conscientização política, doutrina, luta por posições de força e ganho de espaço nas deliberações são elementos pertencentes ao processo. A sinergia de tais movimentos é bem sintetizada no excerto:

A ausência de respostas de um Estado que se abstêm diante dos problemas urgentes dos despossuídos, bem como a difusão das propostas socialistas que adquiriram força no terreno governamental, garantiram o progresso ao Estado Social, à procura de ações concretas, de políticas púbicas. (ALARCÓN, 2011, p. 101)

A parelha justiça e liberdade é chave neste modelo estatal, sendo o ponto distintivo do arranjo anterior ${ }^{6}$. Percebe-se a liberdade permaneceu presente e não deixou de ser um valor essencial, mas nem sempre quando um novo modelo surge em resposta aos problemas do anterior, todas as qualidades institucionais são mantidas, ocasionando distorções e retrocessos.

De plano, é possível ver que a pressão por atuação positiva do Estado cresceu vertiginosamente, e isso não se faz sem um impacto no desenho e organização estatal, além da alteração das funções assumidas, conforme tratado no próximo tópico. Seguindo o processo dialético de avanços e retrocessos, é preciso assentar que o Estado Social não atingiu todo seu desenvolvimento, com precisão de formas institucionais, valores fundamentais e capacidade de preservação (BONAVIDES, 2012, p. 50). Ou seja, não logrou encontrar sua legitimidade e estabilidade tal qual o Estado liberal antecedente em seu ápice.

Em razão disso, continuar a trajetória de modo linear não é tão simples. Em termos históricos, ainda estamos próximos; talvez no futuro, com maior afastamento, as características gerais do processo que segue até hoje sejam delimitadas de forma mais sólida.

De todo modo, críticas ao modelo social foram dirigidas pela insatisfação com a qualidade dos serviços pelo Estado, os altos gastos envolvidos e a intervenção estatal em aspectos econômicos, pensamentos expostos por Friedrich Hayek e Robert Nozick

\footnotetext{
${ }^{6}$ Sobre o plano normativo, vale menção a Constituição Mexicana de 1917 e a Alemã 1919, bem analisados por Fábio Konder Comparato (2013, p. 189-211).
} 
(ALARCÓN, 2011, p. 104). O Estado neoliberal surgiu dessa conjuntura de valorização do livre mercado e desmonte estatal, tendo como marco teórico a obra de Milton Friedman ${ }^{7}$, Capitalism and Freedom, lançada em 1962.

$\mathrm{Na}$ América Latina a situação é ainda mais peculiar porque no período (décadas de 60/70) a região conviveu com Estados ditatoriais, que quando declinaram anos mais tarde, deixaram como legado fortes complicações econômicas e necessidade urgente do próprio processo de democratização (ALARCÓN, 2011, p. 103). Esse contexto influenciou as transformações e discussões sobre o modo de organização do Estado latino-americano e abertura desses países ao contexto global.

Em outra visão, mais teórica, Paulo Bonavides coloca como último modelo o Estado constitucional da Democracia participativa (Estado Democrático de Direito), no qual se busca concretizar os direitos fundamentais (direitos individuais e sociais estabelecidos anteriormente, além de outros incorporados), em proveito e com participação do povo, em atenção à soberania popular (2012, p. 53-54).

O traço distintivo marcante é fidelidade à vontade popular, que para ser expressa necessita de garantias, que diferem o modelo de uma simples justaposição do Estado liberal e do Estado social:

Destarte, o grande desafio do Estado Democrático de Direito seria impedir que as suas funções sociais se transformem em funções de dominação, em vista do poderio que atribuem à máquina estatal. Reprimindo tais funções de dominação estatal, teríamos no Estado Democrático de Direito tanto liberdade negativa como liberdade positiva, marcada pela extensão dos direitos políticos, sociais, econômicos e culturais. Por isso o Estado Democrático de Direito é algo novo. (MORAES, 2014, p. 278)

A missão, na verdade, é conseguir conferir legitimidade e estabilidade ao modelo, que faltaram no Estado Social, através da inclusão da democracia e participação no cerne do estado, permeando todos os demais direitos e atuação estatal. Porém, existem dificuldades de concretização:

O Estado que o define [...] esbarra em dificuldades de concretização, que não são, todavia, inarredáveis, qual o cuidam os publicistas do retrocesso e das situações conservadoras.

$[\ldots]$

${ }^{7}$ FRIEDMAN, Milton. Capitalismo e Liberdade. Trad. Afonso Celso da Cunha. Rio de Janeiro: LTC, 2014. 
Até mesmo os direitos da primeira dimensão apresentam níveis distintos de observância e execução, posto que tenham já solvido por inteiro problemas de formulação teórica. (BONAVIDES, 2012. p. 54-55)

Portanto, ainda que a corrente neoliberal exerça influência em maior ou menor medida em dados momentos - e existam sempre avanços e retrocessos -, o caminho percorrido assentou de forma profunda algumas funções sobre as quais o Poder Público não pode mais se desincumbir e retroceder. Mesmo reformas tidas como neoliberais não foram capazez de suprimir totalmente as instituições do Estado Social em grandes países (CASTELLS, 2016, p. 189-190). Ademais, quaisquer mudanças que venham a ser feitas têm de obedecer ao processo democrático, em que pesem as disfunções presentes no modo de exercício da democracia.

Por fim, ao analisar os elementos do modelo estatal no século passado, Helio Saul Mileski faz uma constatação notável:

Contudo, a regularidade de ação do Estado Democrático de Direito depende de um
fator que não ficou estruturado de maneira satisfatória no século XX, o sistema de
controle. Embora tenha ocorrido o estabelecimento da legalidade e da legitimidade
do exercício do Poder do Estado, o sistema de controle da sua ação administrativa se
mostrou insipiente para evitar o desperdício de dinheiro público, de exigir das
autoridades o comprometimento com políticas de interesse da população; de
combater os atos de corrupção etc. Por esses motivos, possivelmente o século XXI
será o século do controle. ( 2009 , p. 91 , grifo nosso).

Do exposto, a participação e acompanhamento das ações pelo titular do poder (o povo) são impressões presentes no estágio atual, conceitos estes que estão muito arraigados a noção de controle, conforme se verá. Como dito, não existe plenitude na concretização de um Estado assim definido, sendo que parâmetros ideais estão sempre em debate, prevalecendo no momento o controle em destaque. Para os fins deste estudo a trajetória descrita é suficiente.

\subsubsection{Ampliação das Funções do Estado e a Reforma Gerencial no Brasil}

Este tópico busca situar o país dentro do contexto do trecho anterior, com um recorte sobre a história mais recente e determinante para estudo.

No Brasil, o processo de construção do Estado teve a significativa ruptura de 1964, que descontinuou a inclinação popular de democratização. José Afonso da Silva explica o processo de forma muito didática e sucinta, bem como os impactos causados. Ao se opor a tendência democrática, o regime instaurado distanciou-se da fonte originária de poder, que é o povo, tendo como resultado uma severa crise de legitimidade. A produção normativa 
subsequente, inclusive na ordem constitucional, de viés autoritário, teve como fim maior a segurança nacional, além da centralização em matéria financeira e tributária (SILVA, 2011, p. 81).

A solução para manter a estabilidade interna e conter aspirações por direitos humanos fundamentais foi a centralização federal, com inchaço do Poder Executivo neste nível. Um detalhe enfatizado pelo autor, consequência desse modelo, foi a supressão de governantes políticos por tecnocratas, inflexíveis, reacionários e fechados. Portanto, não havia controle político sobre as decisões e condutas, o que é necessário para o equilíbrio entre os poderes e entre esses e a sociedade (SILVA, 2011, p. 82). Não é simples de se desfazer de uma herança como esta, mas a necessidade de mudar profundamente as bases do Estado era urgente.

A Constituição de 1988, que nasceu nesse cenário, buscou recuperar os valores perdidos, imputando ao Estado, como contrapartida, uma atuação extremamente ampla, com garantias de ordem negativa e positiva, além da preocupação com a soberania popular. A inserção do povo nos processos decisórios e controle é uma característica bastante presente. Em linhas gerais, a Constituição de 1988 estabeleceu, no papel, o Estado Democrático de Direito, como descrito acima.

São numerosos os aspectos que podem ser analisados a partir do advento da nova constituição, mas para evitar digressões, sobre o ponto central da pesquisa, o regime adotado está umbilicalmente ligado ao controle:

Primeiramente, o controle representa um elemento do regime democrático e do Estado de direito. Não há como dissocia-lo destes. Como o regime democrático se funda na ascendência do povo quanto à soberania estatal, permitindo-lhe, inclusive, escolher seus representantes, como expressa o art. $1^{\circ}$, parágrafo único, da $\mathrm{CF} / 1988$ [...], não se pode conceber sua existência sem que haja fiscalização sobre todas as atividades do Estado. [...] Da mesma forma, o Estado de direito reclama os instrumentos de controle para verificação da observância de seus parâmetros, evitando que se transforme no Leviatá, de Hobbes - o monstro do livro de Jó. (ALMEIDA; CARVALHO FILHO, 2014, 2014, p. 36)

O excerto acima é preciso pois associa o controle às duas diferentes faces do modelo: i) o controle como forma de limitação da atuação estatal, em seu aspecto liberal; e ii) demonstra especial preocupação em seu aspecto democrático, com participação popular no controle da Administração Pública como desdobramento de sua soberania. A comprovação é facilmente percebida pela expansão de dispositivos constitucionais que tratam direta ou 
indiretamente da matéria, a exemplo dos artigos 31, 70, 71, 75 da Constituição Federal de 1988.

Seguindo na linha temporal, em oposição à herança tecnocrata anterior, a Reforma Gerencial do Estado de 1995 foi a tentativa de compatibilizar o novo ordenamento constitucional, no cenário de dificuldades fiscais, à necessidade de inserção no mundo globalizado e pressão por concretude de direitos prestativos por parte do Estado (BRESSER PEREIRA, 2012, p. 02). A reforma foi conduzida pelo Ministério da Administração e Reforma do Estado ${ }^{8}$, comandado por Luiz Carlos Bresser Pereira.

O New Public Management foi o movimento que importou para a gestão pública as soluções de governança corporativa, esta entendida como os "processos, políticas e regras que dizem respeito à forma de gestão das empresas em relação com os stakeholders, sendo estes os acionistas ou grupos apoiadores, para que haja [...] a responsabilização e o monitoramento das ações dos gestores" (NOHARA, 2016, p. 93-95).

No Brasil, a proposta foi contemplada no Plano Diretor da Reforma do Estado, que diagnosticou problemas, estabeleceu objetivos, traçou estratégias e planos de atuação 9 (BRASIL, 1995), seguindo o padrão de reforma europeu que se iniciara anos antes, sob o mote da eficiência, descentralização de funções, redução do formalismo burocrático, manejo dos gastos públicos e valorização do controle de resultados (BRESSER PEREIRA, 2012).

No plano normativo deve ser destacada a Emenda Constitucional 19/1998, que com regulamentação posterior permitiu: flexibilizar a relação entre administração e agentes; aumentar a autonomia gerencial e financeira de órgãos da administração direta e entidades da administração indireta; estabelecer parcerias com entidades privadas, sem finalidade lucrativa, para prestação de serviços de utilidade pública e interesse social, através do fomento e fiscalização estatal; e acrescentou o princípio da eficiência no art. 37 da Constituição (ALEXANDRINO; PAULO, 2017, p. 145-146).

Como dito, Luiz Carlos Bresser Pereira foi o grande nome por trás dessa reforma, e o autor descreveu sua experiência na obra Reforma do Estado para a Cidadania: a reforma genrencial brasileira na perspectiva internacional, de sua autoria (1998), reafirmando as

\footnotetext{
${ }_{9}^{8}$ As funções foram posteriormente assumidos pelo Ministério do Planejamento, Orçamento e Gestão, em 1998.

9 É interessante que o plano afirmou que a Constituição de 1988 representou um retrocesso no campo da administração gerencial, principalmente sobre a administração indireta, pelo loteamento de cargos de direção e aplicação do mesmo regime jurídico da administração direta (BRASIL, 1995, p. 20-21)
} 
balizas do Plano Diretor da Reforma do Estado. Ocorre que apesar do discurso do desempenho o propósito da citada emenda, ponto central da reforma, foi tão somente a redução de custos, e os governos subsequentes não se preocuparam com a valorização do pessoal, mas somente na redução remuneratória (GABARDO, 2002, p. 66-67 apud NOHARA, 2016, p. 100). Portanto, houve certo descolamento entre a teoria prévia e a prática no caso brasileiro.

O próprio estudioso responsável confirma que a reforma não se completou, sendo um processo em contínua implementação (BRESSER PEREIRA, 2012, p. 03). Nem sempre as decisões são tomadas no que se propôs no plano da reforma, pois a depender do momento econômico e político que o país atravessa, além do contexto externo, o governo caminha em um diferente sentido, a exemplo da criação de estatais e privatizações. Porém, independentemente destas variações, o valor da eficiência foi definitivamente incorporado no ordenamento jurídico brasileiro.

E mesmo que a reforma não tenha sido completa, Irene Nohara é bastante crítica ao modo como ela se deu no país, em artigo todo dedicado para as consequências da mesma sobre a cidadania (2016, p. 93-114). A inspiração para o caso brasileiro foi a fase inicial do New Public Management, o gerencialismo, de viés liberal e que "não absorveu a dimensão sociopolítica das transformações que a própria New Public Management sofreu" (NOHARA, 2016, p. 98), com foco quase exclusivo no aspecto dos custos da máquina estatal. Portanto, o país adotou o início do movimento como inspiração, mas não acompanhou a sua evolução, como ocorreu em outros países (ABRÚCIO, 1997, p. 20-27).

Vale ressaltar que, após tais mudanças, questiona-se se a gestão pública ainda se difere tanto estruturalmente da gestão privada (SANTOS, 2014, p. 50-51). Gestão pública é gerência da função administrativa do Estado de forma delimitada no tempo e espaço, entendida como um processo decisório dinâmico, levando em consideração o planejamento, a organização, a direção e o controle (SANTOS, 2014, p. 47). A gestão privada tem como diferencial a maior liberdade pela diferença de regime jurídico, objetivos predominantemente econômicos, direcionados ao lucro, e viés mais individual. Contudo, após a busca por eficiência, ou mera redução de custos, pelo setor público, o distanciamento reduziu.

Não se pode desconsiderar as limitações e desafios próprios da Administração Pública, sujeita a um regime jurídico complexo e por vezes contraditório. Ademais, os casos de 
corrupção que são rotineiramente divulgados demonstram que ainda não foi encontrada a forma ideal de gerir os bens e interesses públicos. Por isso, os aspectos do planejamento, organização, direção e controle devem ser habilmente manejados, com máximo de zelo e primor.

\subsection{Conceitos, elementos e classificações do controle}

Com as premissas necessárias estabelecidas, o conceito de controle e seus elementos precisam ser bem delimitados, ainda mais dentro do Direito Administrativo. Não existem muitas obras nacionais que se dedicam exclusivamente sobre o controle da Administração Pública de forma ampla, sendo mais usual o tema ser tratado por meio de recortes, ou de forma genérica, porém mais superficial em manuais de Direito Administrativo. Por essa razão, a obra da professora Odete Medauar (2014), será de essencial importância neste item.

De início, desconsiderando a origem etimológica da palavra, o termo controle possui diferentes acepções. Com base na doutrina italiana, a autora faz um interessante escalonamento das diferentes acepções com base na gradação da força de seus sentidos (MEDAUAR, 2014, p. 22-23). Assim, o mais forte dos sentidos é o de dominação, que transmite a ideia de subordinação, e quando empregado pode ser distorcido para o abuso.

Controle como direção significa o poder de influência determinante, sendo o segundo sentido mais forte, atrelado ao comando. Na sequência, a acepção de limitação impõe barreiras que não se deve ultrapassar, trazendo então um aspecto negativo. Os dois próximos sentidos, já menos intensos, são bastante próximos: fiscalização e verificação. Os termos são autoexplicativos, mas se diferem porque o primeiro exprime uma noção de continuidade, enquanto o segundo indica exames específicos, com finalidade determinada.

Na última acepção, a mais fraca de todas, existe controle como registro, que seria a mera inscrição ou assentamento para fins de identificação de parâmetros, atividade mais comum e precursora do controle.

Há então a reflexão, que justifica a explicação feita, sobre quais das acepções seriam pertinentes ao controle da Administração Pública. Odete Medauar esclarece que, diante das diversas formas de controle presentes no Direito Administrativo, tanto os sentidos fortes como fracos estão presentes, embora essa sua posição não seja uníssona (MEDAUAR, 2014, p. 2324). Em atenção a todos os mecanismos e atuações do controle hoje existentes, a posição da autora é correta, mas seria possível fazer uma ressalva quanto ao sentido de dominação. A 
atividade de controle, nos moldes que serão expostos, dificilmente poderia ser considerada legítima ${ }^{10}$ em um Estado Democrático de Direito quando empregada ao ponto de dominar a atividade controlada.

\subsubsection{Conceito e elementos}

O estudo das acepções e sua pertinência auxilia a esclarecer no que consiste o controle, mas não o conceitua de forma clara para os limites que aqui se propõe. As noções de conformação, fiscalização e correção são quase sempre imediatamente associadas ao controle. Para exemplificar, colacionam-se alguns conceitos presentes na doutrina, em que é possível ver as correspondências:

- Controle, em tema de Administração Pública, é a faculdade de vigilância, orientação e correção que um poder ou autoridade exerce sobre a conduta funcional de outro" (MEIRELLES, 2018, p. 672)

- "Podemos denominar de controle da Administração Pública o conjunto de mecanismos jurídicos e administrativos por meios dos quais se exerce o poder de fiscalização e de revisão da atividade administrativa em qualquer das esferas de Poder" (CARVALHO FILHO, 2013, p. 941)

- “Controle administrativo é o poder de fiscalização e correção que sobre ela exercem os órgãos dos Poderes Judiciário, Legislativo e Executivo, com o objetivo de garantir a conformidade de sua atuação com os princípios que lhe são impostos pelo ordenamento jurídico" (DI PIETRO, 2012, p. 792).

Esses excertos demonstram que há certa coincidência. Os elementos fiscalização e correção são frequentemente lembrados como presentes na atividade de controle, como formar de conformar o exercício do poder estatal na função administrativa aos ditames constitucionais e legais. Sobre o tema, José dos Santos Carvalho Filho inclusive chega a afirmar:

A fiscalização e a revisão são os elementos básicos do controle. A fiscalização consiste no poder de verificação que se faz sobre a atividade dos órgãos e dos agentes administrativos, bem como em relação à finalidade pública que deve servir de objetivo para a Administração. A revisão é o poder de corrigir as condutas administrativas, seja porque tenham vulnerado normais legais, seja porque haja necessidade de alterar alguma linha das políticas administrativas para que melhor seja atendido o interesse coletivo. (2013, p. 941)

\footnotetext{
${ }^{10}$ Legitimidade aqui utilizada para além da legalidade formal, em conformação com o ordenamento jurídico como um todo, inclusive princípios explícitos e implícitos (ALEXANDRINO; PAULO, 2017, p. 996).
} 
Em análise mais profunda, a discussão sobre os elementos do controle não é tão simples. O apontamento de características essenciais, e que portanto estariam presentes em todas as formas de controle, não é uniforme na doutrina. Odete Medauar, com apoio na doutrina italiana, elenca essas discussões para após chegar a um conceito "ideal" de controle (2014, p. 27-32), conforme se passa a discorrer.

A necessidade de diferenciação de sujeitos, órgão controlador diverso do controlado, é o primeiro atributo a ser analisado. A característica tem razão de ser apontada, pois é comum que haja essa diferenciação na prática, ainda mais comum na origem dos estudos, em que o maior exemplo de controle era do poder central sobre o restante da Administração (MEDAUAR, 2014, p. 27). Contudo, as ressalvas impedem que se ateste a essencialidade da característica. No autocontrole, em que a autoridade exerce o controle sobre si mesma, e também do controle hierárquico, quando existe subordinação entre o controlador e o controlado, não é verificada a dualidade de órgãos.

No segundo caso, do controle hierárquico, existe diferenciação de agentes, mas não há de órgãos, o que permite aproximar o atributo. Para garantir maior generalidade, a autora ensina que a diferenciação de "vontades" ou agentes é um dos elementos caracterizadores do controle, feita a exceção da fiscalização da autoridade sobre o próprio ato (2014, p. 28).

Prosseguindo, questiona-se sobre a necessidade de um ato ou conduta precedente passível de controle (MEDAUAR, 2014, p. 28). De plano, o problema é que esse atributo excluiria o controle preventivo ou concomitante, realizados para evitar que eventual irregularidade sequer ocorra ${ }^{11}$. Por mais que em parcela expressiva das situações a atividade de controle atinja uma atividade anterior, não é o suficiente para ser um elemento identificador do controle.

A atividade de controle é realizada para que se forme um juízo a respeito do objeto da fiscalização ou verificação, ou seja, avaliação de conformidade do ato com os parâmetros que o regulam (MEDAUAR, 2014, p. 28). Perceba-se que neste ponto não se fala de correção ou sanção por eventual desvio, até mesmo porque o juízo pode ser positivo ou negativo, sem que se afete a característica aqui analisada.

\footnotetext{
${ }^{11}$ As tipologias do controle serão analisadas no tópico 3.2.2
} 
O ponto mais controvertido, entretanto, é a necessidade de reação após o juízo feito pelo controlador, quando constatada irregularidade ou suspeita, para caracterizar o controle: “[o] posicionamento de Giannini, acentuando a caracterização do controle na medida, suscita até hoje discussões na doutrina italiana. Há estudos que rejeitam a medida como essencial; outros aceitam; e se busca, também, atribuir sentido amplo à palavra medida" (MEDAUAR, 2014, p. 30).

Massimo Severo Giannini, autor italiano que defendeu a medida como elemento do verdadeiro controle, explica que essa poderia ter caráter apenas potencial, mas não deixaria de ter que estar presente (1974, p. 1279, apud MEDAUAR, 2014, p. 29-30). Em outras palavras, o importante seria a possibilidade de aplicação de alguma providência cominatória para eliminar eventual irregularidade, mesmo que no caso concreto o juízo fosse pela legitimidade do ato ou conduta controlada. A estrutura jurídica da atividade controladora precisaria internalizar a medida em seu procedimento.

Por outro lado, o requisito se mostra restritivo, ainda mais considerando o aumento do número de normas de orientação, que se exprimem na forma de recomendações ou incentivos, sem força vinculativa (soft law). Ademais, pareceres opinativos oriundos de órgãos consultivos e consultas a sociedade civil seriam excluídos dos estudos dos mecanismos de controle (MEDAUAR, 2014, p. 32).

Uma das soluções possíveis para abarcar um número maior de situações é ampliar o conceito de medida. No limite, a mera existência da atividade de controle pode incutir no agente uma maior responsabilidade, sabendo que seus atos e decisões poderão ser revistos e ele ser responsabilizado por desvios: “É a chamada 'vocação preventiva' de todo sistema de controle eficaz, pois deve suscitar na própria Administração uma deontologia que previne o arbítrio e se integra na sua atuação" (MEDAUAR, 2013, p. 423). O controle quando exercido de modo eficaz produz efeitos de uma liberdade vigiada. Não é uma consequência direta ou automática, mas pode ser uma "medida" preventiva apta a caracterizar o controle.

Noutro giro, a solução adotada por Odete Medauar foi diferente e conciliadora, elaborando dois conceitos, um amplo e outro restrito de controle, que merecem transcrição, primeiramente a acepção restrita: “[c]ontrole da Administração Pública é a verificação da conformidade da atuação desta a um cânone, possibilitando ao agente controlador a adoção de medida ou proposta em decorrência do juízo formado” (2014, p. 32). 
Em sequência, mais inclusivo e adequado, por exemplo, com o controle social, o segundo conceito: “[e]m acepção ampla, o controle significa a verificação da conformidade da atuação da Administração Pública a certos parâmetros, independentemente de ser adotada, pelo controlador, medida que afete, do ponto de vista jurídico, a decisão ou o agente" (2014, p. 32).

Como será visto ao longo do estudo, o conceito aberto de controle é mais adequado aos objetivos propostos, até mesmo por refletir com maior clareza os anseios, dilemas e propostas atuais de mudança.

\subsubsection{Tipologia}

No estudo de um determinado instituto amplo, as tipologias auxiliam na compreensão por meio do fracionamento do gênero em espécies que compartilhem critérios identificadores uniformes (ALMEIDA; CARVALHO FILHO, 2014, p. 38). Contudo, não é raro encontrar discrepâncias entre os diferentes autores ao elaborar classificações.

Apesar do fim didático, a utilidade das tipologias elaboradas pela doutrina também precisa ser considerada, pois classificar apenas por classificar pode apenas causar mais dificuldade (ALEXANDRINO; PAULO, 2017, p. 828). Assim, além da coerência expressa pela constância da aparição do critério dos grupos, a tipologia útil precisa da aceitação por parte considerável daqueles que se dedicam ao tema.

Por isso serão selecionadas as classificações que se mostram úteis ao estudo proposto, atendendo ao máximo as premissas supra, sem pretensão de explorar a totalidade das tipologias e suas variações.

\subsubsection{Quanto ao aspecto subjetivo do controle}

Esse critério é baseado na origem do controle em relação à estrutura da Administração, sendo um dos mais relevantes e mais utilizados modos de classificar o controle. Assim, o referencial para classificação será a posição do Poder responsável pelo controle (MEDAUAR, 2014, p. 52).

Em linhas gerais, será interno todo controle "exercido por órgãos do mesmo Poder no que diz respeito às atividades administrativas praticadas dentro de sua esfera" (ALMEIDA; CARVALHO FILHO, 2014, p. 40). Portanto, é a Administração controlando a própria Administração. Nesse sentido, Miguel Seabra Fagundes há muito já destaca a importância do 
controle interno para corrigir "os defeitos de funcionamento interno do organismo administrativo, aperfeiçoando-o no interesse geral, e ensejar a reparação a direitos e interesses individuais, que possam ter sido denegados em consequência de erro ou omissão na aplicação da lei" (1984, p. 88).

Importante observar que os demais poderes, no exercício de suas funções atípicas administrativas, também devem zelar pela regularidade dos atos e atividade realizados. Portanto o controle interno, pela definição exposta, não é uma particularidade do Poder Executivo, existindo também no Legislativo e no Judiciário, embora nesse se concentrem as funções administrativas do Estado. Nesse sentido, a Constituição de 1988 dispôs expressamente no art. 74 que todos os poderes deverão manter sistema de controle interno integrado.

O critério subjetivo, contudo, não se limita a dividir o controle entre interno e externo. Como bem explica Thiago Marrara, além de ser possível privilegiar a posição do controlador em relação ao controlado, como foi feito, é possível prestigiar a natureza do controlador:

\begin{abstract}
Ao se utilizar critérios subjetivos de classificação, ora se valorizam a natureza do controlador, ora seu posicionamento diante do controlado - este sim o critério que d'origem ao chamado controle interno. Já no primeiro sentido mencionado, ou seja, à luz do critério da natureza do órgão controlador, separam-se o controle executado por órgãos com função jurisdicional; o controle realizado por órgãos com função legislativa primária e o controle administrativo, a cargo de órgãos com função executória ordinária. (2016, p. 49)
\end{abstract}

Neste momento foram apenas explicadas as tipologias, sendo que essa divisão em controle legislativo, judicial e administrativo aparece na doutrina (CARVALHO FILHO, 2013, p. 943). Contudo, Miguel Seabra Fagundes, já utilizava esse critério para apresentar um sistema tríplice de controle antes mesmo da atual Constituição (1984, p. 86-87), e que por permitir uma visão didática dos controladores e a relação entre eles, essa segmentação será utilizada para análise do panorama brasileiro, com maior grau de profundidade no Capítulo 4.

Retornado ao enfoque anterior, por exclusão, serão externos os controles quando exercidos por agente ou órgão estranho ao Poder cuja atividade está sendo controlada. $\mathrm{O}$ fundamento do controle nestes casos é o equilíbrio que deve existir entre os Poderes, cada qual cumprindo suas missões constitucionais, o que permite conferir legitimidade à função 
administrativa (ALMEIDA; CARVALHO FILHO, 2014, p. 41) ${ }^{12}$. A ausência de hierarquia administrativa implica em restrições ao controle assim exercido, tornando-o menos amplo ou condicionado, como será visto.

Há, entretanto, um ponto que gera profundas controvérsias, que é a classificação do controle exercido pela Administração Direta sobre a Indireta. Pelo critério aqui exposto, que é o Poder em que se situa o controlador, embora se tratem de pessoas jurídicas distintas, ambas estão situadas no Poder Executivo, razão pela qual o controle deve ser considerado interno. Dessa visão discorda Thiago Marrara, acompanhando Maria Sylvia Zanella Di Pietro (2012, p. 793), nos seguintes termos:

Há duas pessoas jurídicas: uma em posição de monitorado e outra em posição de fiscalizadora. Não há necessidade de dois Poderes envolvidos. Exatamente por isso se diz que o controle externo envolve tanto o desenvolvimento por um Poder sobre o outro, quanto o executado, no âmbito do Poder Executivo, pela Administração Direta em relação à Indireta que lhe esteja vinculada. (2016, p. 50).

Para os autores, portanto, não haveria a necessidade de haver dualidade de Poderes, bastando pessoas jurídicas distintas. A argumentação é no sentido de que a tutela administrativa, denominação usual para o controle exercido sobre a Administração Indireta, é mais restrita do que o controle interno exercido sobre os órgãos integrantes da Administração Direta, já que para aquela é imprescindível previsão legal expressa como forma de submissão ao controle pela Administração Direta (MARRARA, 2016, p. 52).

Porém, alguns administrativas, seguindo a posição do Prof. Celso Antônio Bandeira de Mello, reconhecem a tutela extraordinária, independentemente de previsão, em casos de graves desvios de conduta dessas pessoas jurídicas vinculadas ao poder central, devendo o controle evitar ou corrigir tais situações excepcionais, mesmo na ausência de previsão legal (ALEXANDRINO, PAULO, 2017, p. 959-960). A tutela extraordinária e as dificuldades em separar a vinculação da subordinação na prática administrativa, advogam em favor da corrente que entende a tutela como integrante do controle interno.

Este estudo, para fins de sistematização e proposta de integração dos controles, com a devida vênia às demais posições, seguirá a linha de José dos Santos Carvalho Filho, Odete Medauar, e Edmir Netto de Araújo, que inclusive considera essa classificação, dividido em

\footnotetext{
12 O controle exercido pelo Ministério Público, justamente pelo Parquet não estar inserido ou vinculado a nenhum dos demais Poderes, é uma forma de controle externa (MEIRELLES, 2008, p. 675).
} 
interno e externo, como a mais importante por abranger os demais critérios e por focalizar em determinada Administração os mecanismos de controle (2010, p. 1181).

\subsubsection{Quanto ao objeto do controle}

Nesta outra tipologia, o controle pode ser divido com base naquilo que se pretende controlar: a legalidade ou o mérito do ato. Em relação ao primeiro, a atividade controladora mira realizar um juízo sobre a conformação do ato e o ordenamento jurídico, devendo este ser compreendido de forma ampla, abarcando atos normativos infralegais oriundos da própria administração (decretos, regulamentos, instruções) e também princípios administrativos (ALEXANRINO, PAULO, 2017, p. 954). ${ }^{13}$

Contudo, pode ser que um ato que esteja de acordo com os parâmetros legais aplicáveis, mas mesmo assim seja reexaminado e até revogado. Nestas situações, estará presente o controle de mérito. Como definição, o controle de mérito é o julgamento de conveniência e oportunidade do ato controlado, com base em critérios de avaliação, quando há margem de escolha na atuação, sempre com base no interesse público, sendo, em geral, ligado ao poder discricionário da Administração (ALEXANDRINO; PAULO, 2017, p. 955; ALMEIDA; CARVALHO FILHO, 2014, p. 44-45)

Ambas as formas são de extrema importância para a função do controle, posto que a legalidade é um dos valores mais importantes para o Estado de Direito, expresso no art. 37 da Constituição como princípio de observância cogente para toda a Administração. Já que não é possível enquadrar toda a atividade administrativa dentro da legalidade estrita, com previsão da totalidade de situações que podem ocorrer, o controle de mérito, por sua vez, é essencial para função administrativa seguir os rumos devidos, considerando a fluidez dos interesses em jogo e novas circunstâncias de fato que podem influenciar no ato controlado. Embora permaneça legítimo, pode o ato já não ser o mais adequado aos fins que se prestam.

De certa forma o controle de legalidade precede o de mérito, pois não faz sentido verificar oportunidade e conveniência de um ato ilegal que deva ser anulado. A adequação aos parâmetros legais então é condição para a avaliação de conveniência e oportunidade, mas isso não significa que eventual ato que substitua o anterior revogado não deva também passar pelo crivo do controle de legalidade.

\footnotetext{
13 Nesse sentido, a EC 45/2004 introduziu no ordenamento a obrigatoriedade de observância às súmulas vinculantes editadas pelo Supremo Tribunal Federal, instituindo novos parâmetros de controle.
} 
Característica importante do controle de legalidade é seu viés objetivo, já que o confronto com as normas aplicáveis levará a um julgamento positivo ou negativo, com subsunção ou não há regra. As consequências também são definidas em lei. Sendo legal o ato controlado, ele pode ser autorizado, confirmado, homologado, entres outros. Do contrário, a consequência pode ser a anulação ou convalidação, nos casos permitidos também por lei, já a discricionariedade no campo é limitada justamente pela objetividade.

A consequência principal dessa constatação é que o controle de legalidade pode ser realizado pelo responsável pelo ato, dentro do controle interno, como também pode ser feito externamente. O controle de mérito, por sua vez, deve ser realizado pela própria Administração, nos termos da Súmula 473 do Supremo Tribunal Federal ${ }^{14}$, que consagra a possibilidade de revogação do ato por motivo de conveniência e oportunidade, orientação de aplicação prática muito relevante.

Por envolver sindicância mais profunda, envolvendo decisões inerentes a atividade de gestão dos interesses que foi outorgada à Administração, inicialmente ao controle externo é vedado examinar o mérito do ato administrativo. Essa questão gera debates, em especial quanto ao controle judicial ${ }^{15}$.

Odete Medauar expõe duas correntes opostas quanto a amplitude do controle feito pelo Poder Judiciário. A primeira, restrita, entende que somente a legalidade da atividade administrativa seja passível de revisão. Prioriza-se a separação dos poderes, valor historicamente essencial, e ausência de mandato eletivo que confira ao Estado-Juiz legitimidade para fazer escolhas relativas ao interesse público. A segunda corrente defende o controle amplo, sob a justificativa de que para que haja equilíbrio entre os poderes, deve-se ser facultado ao Judiciário limitar o Executivo, sem que isso seja considerado indevido. Ademais, não seria o voto o único meio capaz de legitimar o poder, pois o trabalho técnico, imparcial e motivado tem o condão de fazer com que mesmo o exercício anormal seja reconhecido, como ocorre na jurisdição constitucional (2014, p. 221-223).

Contudo, essa divisão estanque entre legalidade e mérito não possui mais contornos tão bem definidos. A objetivação dos elementos do ato administrativo, a necessidade de

\footnotetext{
14 A redação da súmula é a seguinte: A administração pode anular seus próprios atos, quando eivados de vícios que os tornam ilegais, porque deles não se originam direitos; ou revogá-los, por motivo de conveniência ou oportunidade, respeitados os direitos adquiridos, e ressalvada, em todos os casos, a apreciação judicial.

${ }^{15}$ Vide item 4.3.
} 
motivação e a eficiência como valor constitucional, reduz o campo de opções justificáveis do administrador mesmo em atos tidos como discricionários, o que fortalece as possibilidades de controle, qualquer que seja a corrente adotada. Maria Sylvia Zanella Di Pietro, por exemplo, aduz que o exame dos motivos por fatos precedentes à elaboração do ato, sua ausência ou falsidade não caracteriza invasão do mérito administrativo (2012, p. 811).

Como fechamento, a lição de Phillip Gil França sobre a real importância dos limites ao controle é precisa, com a qual se concorda:

Importante ressaltar que nenhum dos meios de controle da atividade estatal pode agir de modo a substituir a atuação administrativa da Administração Pública, da mesma forma que nenhum ato da Administração Pública deve estar voltado a furtarse da necessária sindicabilidade jurisdicional de verificação de meios e fins da atuação executiva estatal. (2016, p. 174)

\subsubsection{Quanto ao momento do controle}

Outra classificação usual, sem maiores digressões neste estudo, é quanto ao momento em que o controle se realiza. Este será prévio quando o controle for feito antes da prática ou conclusão do ato controlado, podendo a lei estabelecer esse procedimento como requisito a validade ou eficácia deste (ALEXANDRINO; PAULO, 2017, p. 952).

Exemplos típicos deste modo de controle são a aprovação prévia para prática de ato que dependa de juízo sobre aspecto técnico a ser realizado pelo controlador, autorização do Senado para que os entes políticos contraiam empréstimos externo, e até mesmo a concessão de liminar em mandado de segurança preventivo impetrado por particular questionando ato que será praticado pela Administração, por ser vinculado. Apesar do interessante caráter preventivo, este modo de controle não é o mais usual, e nem poderia ser:

Na rotina administrativa, esse tipo de controle não é o mais comum. Aliás, seria impossível que o fosse, porquanto não se poderia conceber que antes de cada passo o órgão administrativo submetesse seu futuro ato a uma fiscalização prévia. Semelhante providência simplesmente deixaria inerte a Administração, com flagrante violação ao princípio da eficiência. (ALMEIDA; CARVALHO FILHO, 2014, p. 51)

Em outras situações, o controle pode acompanhar a atividade ou conduta administrativa, desenvolvendo-se ao mesmo tempo. Esse modo de controle simultâneo visa a regularidade de formação ou execução do ato. Mas para tanto é preciso, por consequência lógica, que não seja exercido em atos instantâneos, que se exaurem ou concluem de imediato. 
Assim, o usual é que incida sobre atividade ou condutas administrativas que se protraem no tempo, como a execução de obra ou orçamento público (ALMEIDA; CARVALHO FILHO, 2014, p. 52).

Como última possibilidade, e mais comum, o controle pode ser realizado após a conclusão do ato. Portanto, primeiramente o ato ou conduta são realizados para que depois seja feito o exercício do controle. É possível que o ato seja então confirmado, anulado, revogado ou corrigido. Porém, o termo controle corretivo não é o mais adequado posto que nem sempre haverá de fato uma correção. Pode ser apenas se ateste a regularidade do ato, ou que o mesmo seja revogado, o que não representa em si uma correção.

Como existem diversos órgãos e atividades de controle, sobre um mesmo ato ou conduta pode incidir controle prévio, concomitante e posterior, sendo que eventual conformidade verificada em um momento não prejudica o julgamento dos demais. $\mathrm{O}$ controle posterior, por ser o último no aspecto temporal, deve verificar toda a atividade antecedente, o que o torna mais amplo que os demais e acentua seu caráter repressivo.

O problema é que o ato irregular pode já ter gerado efeitos indesejáveis, que por vezes são irreversíveis. Há muitas situações em que não se pode retornar ao status quo mesmo apurada a irregularidade por meio do controle posterior. A vantagem do controle prévio seria então evitar a ocorrência do dano, mas o custo em celeridade pode ser muito alto. Os sistemas de controle não têm condições de recursos materiais, humanos e tempo para controlar previamente toda a atividade administrativa, além do risco de vir a substituir a existência do administrador, o que cria um impasse. Sob pena de adiantar assuntos que serão tratados, interessante dizer que o uso de novas tecnologias de informação e comunicação, neste ponto, pode ser um caminho ao encurtar o tempo dispendido para se realizar a mesma atividade de controle, reduzir custos em escala, para assim permitir que, quando essencial, o controle seja feito previamente sem o inconveniente do engessamento.

\subsubsection{Outras tipologias}

Como foi expresso, as classificações utilizam critérios condizentes com os fins almejados e também por conveniência dos elaboradores. Logo, emitir um juízo sobre as tipologias mais importantes de modo abstrato é uma tarefa inverossímil. Talvez conforme novos estudos aparecerem outros modos de classificar os controles se torner mais adequados, alterando os critérios atuais ou introduzindo adicionais. 
Um bom exemplo é o controle social, tratado com maiores detalhes no item 4.5, mas que por sua natureza difusa nem sempre pode ser enquadrado com perfeição nos critérios tradicionais, ou ao menos possui características próprias que merecem medidas particulares. Nesse sentido, o controle social não é uniforme, podendo ser dividido se assim for conveniente.

A sociedade, como titular da res publica e interessada direta nas atividades executivas, por vezes se encontra organizada por meio de instituições (assossicações, coletivos e afins), exercendo um controle organizado em demandas específicas. Mas isso não é uma regra, um elemento necessário no controle social. É plausível, e comum, que esse controle esteja espalhado, exercido individualmente, mas que se soma em um meio de difusão propício, e nem por isso deixará de ser um controle na acepção ampla do termo. Esse arranjo é possível com o advento das novas tecnologias, como será oportunamente tratado.

As lições trazidas auxiliam na compreensão do tema, com nuances que já se alinham com eventuais dificuldades práticas do controle. Apenas como menção, por estar relacionado com outra categorização já feita, é possível separar o controle por sua amplitude, se ele incide sobre um ato específico ou sobre toda a atividade, ou seja, um conjunto de atos e condutas que visam determinado fim. (MEDAUAR, 2013, p. 424). Tal parâmetro de análise guarda relação com a possibilidade de controle concomitante.

O outro aspecto que merece atenção é o modo de desencadear o controle. Com base nesse critério o controle pode ser iniciado de ofício, por iniciativa do próprio agente que praticou o ato ou possui competência para revê-lo; ou pode ser provocado, provocação essa que pode ocorrer das mais variadas formas; forçando a atuação do agente controlador; e por fim há o controle compulsório, em que a própria norma disciplinadora já obriga a atuação do controlador, como parte do procedimento legal (MEDAUAR, 2013, p. 424).

O controle de ofício independe de qualquer atuação de agente externo, sendo realizado pela própria consciência dos agentes envolvidos na prática do ato da importância da atividade pública que realizam, e por isso buscam atender os princípios da legalidade, probidade e eficiência espontaneamente. Infelizmente, o bom funcionamento desta forma de controle não é a regra geral, que depende também de um sistema de controle interno organizado (ALMEIDA; CARVALHO FILHO, 2014, p. 53). 
Como aspecto crítico, esse cenário torna os sistemas de controle mais dependentes de provocação. Felizmente, o maior interesse recente pelo controle faz com que exista mais estímulo para que ela ocorra, seja por órgãos externos com função precípua de controle seja por quaisquer outros interessados, atuando de forma conjunta ou isolada.

Essa atuação pode mitigar os problemas da falta de controle de ofício mencionados acima, embora o mais interessante fosse o equilíbrio. Como aliada para provocar a atividade de controle, as novas tecnologias de informação e comunicação podem ser muito benéficas, já que conhecidas pela facilidade na propagação de acesso, como profundamente examinado nos capítulos 5 e 6. 


\section{O CONTROLE NO BRASIL}

Após analisado o conceito do controle e suas classificações relevantes, este capítulo irá aprofundar ou retomar os temas expostos quando necessário. O objetivo neste ponto é traçar o panorama do controle no país, utilizando como critério o aspecto subjetivo, em especial a natureza do controlador.

Sem perder de vista que os controles se aplicam a todos os Poderes, o referencial para o estudo será o Executivo, sendo que muitos dos controles que serão abordados foram pensados para atingir as atividades realizadas por este Poder, que acumula grande parte da função administrativa.

Ainda pelo mesmo motivo, a primazia será pelo controle interno, assunto que segundo Odete Medauar ganhou expressão nas últimas décadas, o que refletiu em um maior número de publicações sobre o tema (2014, p. 55). Porém, a matéria ainda carece de outros estudos, principalmente em razão das modificações constantes, e porque a prática do controle interno ainda é incipiente. Com isso, espera-se que os itens subsequentes sejam capazes de contemplar o cenário atual, proposições de mudanças e gargalos impeditivos.

\subsection{Sistema de controle interno}

Antes de tudo um esclarecimento. A expressão controle administrativo é bastante utilizada para designar o controle exercido pela Administração sobre sua própria função administrativa, sendo por vezes empregada com pouco critério e quase como um sinônimo de controle interno. Pensando no aspecto subjetivo de classificação, quando a ênfase é dada à posição do controlador, o controle será interno, e quando o enfoque é a natureza do controlador o controle pode ser dito administrativo (MARARRA, 2016, p. 49).

Mas mesmo com a diferenciação, o uso da expressão pode levar a confusão, pois os vocábulos em geral empregados na composição das expressões são polissêmicos. Parar exemplificar, controle administrativo pode ser entendido como o controle exercido pela Administração Pública, de forma ampla, sobre qualquer sujeito ou objeto, por força do vocábulo administrativo (MEDAUAR, 2014, p. 52). Não fica claro de plano se o sentido é o controle exercido pela ou sobre a Administração Pública.

Sendo assim, em que pese o critério subjetivo utilizado, o tópico foi nomeado sistema de controle interno principalmente para seguir a disposição constitucional, que adotou 
expressamente o termo. Ademais, com isso divergências são evitadas e também se reforça a importância da organização e coordenação que a ideia de sistema traz consigo.

A existência de sistemas de controle interno em todos os poderes é uma determinação constitucional, conforme positivado no art. 74, que merece transcrição:

\begin{abstract}
Art. 74. Os Poderes Legislativo, Executivo e Judiciário manterão, de forma integrada, sistema de controle interno com a finalidade de:

I - avaliar o cumprimento das metas previstas no plano plurianual, a execução dos programas de governo e dos orçamentos da União;

II - comprovar a legalidade e avaliar os resultados, quanto à eficácia e eficiência, da gestão orçamentária, financeira e patrimonial nos órgãos e entidades da administração federal, bem como da aplicação de recursos públicos por entidades de direito privado;

III - exercer o controle das operações de crédito, avais e garantias, bem como dos direitos e haveres da União;

IV - apoiar o controle externo no exercício de sua missão institucional.
\end{abstract}

Ocorre que não é a mera previsão constitucional que constituirá um sistema de controle eficiente, ou fazê-lo operacionalizar de forma adequada. Um sistema depende de um grupamento funcional, em que cada componente tenha uma atuação definida e em harmonia com os demais, para que o arranjo represente mais do que a simples adição de partes. Nesse sentido, sistema é "conjunto de elementos interdependentes e interagentes no sentido de alcançar um objetivo ou finalidade" (CHIAVENATO, 2003, p. 476) ${ }^{16}$.

Detalhe importante é que a Carta Constitucional menciona o sistema de controle interno também nos artigos 31 e 71, além de determinar que tais sistemas sejam integrados, uma pretensão no mínimo audaciosa. No âmbito da União, a matéria é regulada Lei n. 10.180/2001 e pelo Decreto n. 3.591/2000, mas ainda de forma tímida.

Em síntese, com base nas normas mencionadas, a organização do sistema de controle interno da União tem como órgão central a Controladoria Geral da União (CGU), com a incumbência da supervisão técnica e orientação normativa, as Secretarias de Controle Interno da Casa Civil, da Advocacia-Geral da União, do Ministério das Relações Exteriores e do Ministério da Defesa, como órgãos setoriais, sendo que estes podem subdividir-se em unidades, para especialização de funções ou racionalização geográfica. Destaca-se também a instituição da Comissão de Coordenação de Controle Interno, órgão colegiado de âmbito

\footnotetext{
16 Adotou-se um dos conceitos de sistema trazido pelo autor, mas é preciso fazer o alerta de que para os objetivos deste estudo não se exige um aprofundamento nos diferentes conceitos de sistemas, aplicados a diversas áreas do conhecimento.
} 
federal, criada justamente para promover a integração e homogeneizar entendimentos dentro do sistema de controle.

A CGU foi criada pela Lei n. 10.683/2003, para assessor a Presidência da República na defesa da transparência e do patrimônio público através do controle interno. O novo órgão absorveu as funções da Corregedoria-Geral da União, que havia sido instituída apenas dois anos antes pela Medida Provisória n ${ }^{\circ}$ 2.143-31. As atividades de controle já eram exercidas pela Secretaria Federal de Controle Interno e Ouvidoria-Geral da União, cada qual subordinada a um Ministério distinto (Fazenda e Justiça, respectivamente), e foram vinculadas à Corregedoria após sua criação ${ }^{17}$.

Existem em leis esparsas outras disposições sobre o tema, como por exemplo as atribuições de fiscalização dadas pelo artigo 59 da Lei de Responsabilidade Fiscal ${ }^{18}$, mas a criação de órgãos, mecanismos e objetivos de forma fragmentada não é capaz de conceber um sistema como se almeja. Falta a característica de que o todo seja mais do que a simples somatória de elementos, pois agrupar órgãos ou unidades de controle não é o mesmo do que fazer com que trabalhem eficientemente, com coesão.

E esse é o cenário no nível federal, onde há recursos e condições para formação de um verdadeiro sistema de controle de interno. Os demais entes federativos, limitados, devem organizar seu sistema de controle interno na ausência de diretrizes gerais, o que dificulta o trabalho de sistematização e posteriormente a integração entre diferentes controladores, isso quando o controle interno é de fato implementado, o que não é uma regra.

Diante do problema, está em trâmite a Proposta de Emenda à Constituição no 45/2009, que pretende acrescentar o inciso XXIII ao art. 37 da Constituição Federal, dispondo sobre as atividades do sistema de controle interno. O projeto, que está pronto para deliberação do plenário do Senado (casa iniciadora), possui a seguinte redação para o inciso:

17 O histórico completo da CGU consta do portal eletrônico oficial: <http://www.cgu.gov.br/sobre/institucional/historico>. Acesso em 05 de abril de 2018.

18 Art. 59. O Poder Legislativo, diretamente ou com o auxílio dos Tribunais de Contas, e o sistema de controle interno de cada Poder e do Ministério Público, fiscalizarão o cumprimento das normas desta Lei Complementar, com ênfase no que se refere a:

I - atingimento das metas estabelecidas na lei de diretrizes orçamentárias II - limites e condições para realização de operações de crédito e inscrição em Restos a Pagar; III - medidas adotadas para o retorno da despesa total com pessoal ao respectivo limite, nos termos dos arts. 22 e 23; IV - providências tomadas, conforme o disposto no art. 31, para recondução dos montantes das dívidas consolidada e mobiliária aos respectivos limites;

V - destinação de recursos obtidos com a alienação de ativos, tendo em vista as restrições constitucionais e as desta Lei Complementar; VI - cumprimento do limite de gastos totais dos legislativos municipais, quando houver. 
XXXIII - As atividades do sistema de controle interno da União, dos Estados, do Distrito Federal e dos Municípios a que faz referência o art. 74, essenciais ao funcionamento da Administração Pública, contemplarão em especial as funções de ouvidoria, controladoria, auditoria governamental e correição, e serão desempenhadas por órgãos de natureza permanente, e exercidas por servidores organizados em carreiras específicas na forma da lei.

$\mathrm{Na}$ justificação da proposta consta que a mesma atendeu demandas do Conselho Nacional de Controle Interno dos (CONACI), que representa as solicitações dos próprios agentes de controle interno, na busca por melhorias para o setor (BRASIL, 2009a, p. 02). Inclusive, este Conselho elaborou um documento com diretrizes para o controle interno no setor público, que embora sem qualquer caráter vinculante, contém regras e conceitos gerais que podem auxiliar os entes federativos (CONACI, 2010).

Alinhado com essas orientações, o Substitutivo ao Projeto de Lei complementar $n^{\circ}$ 229/2009 (Lei da Qualidade Fiscal), que estabelece normas sobre finanças públicas (planejamento, orçamento, execução orçamentária e controle), disciplina nos artigos 70, 71 e 72 sobre o controle interno através de regras gerais, com as funções específicas de ouvidoria, controladoria, auditoria e correição (BRASIL, 2016) ${ }^{19}$.

Essas duas possíveis modificações, ao menos no plano normativo, seriam de grande valia, principalmente a estruturação de carreira específica para os agentes de controle interno, seguindo o exemplo do Ministério Público. Com a devida regulamentação, e concessão de prazo para que os Estados e Municípios se adequem e compatibilizem com as especificidades locais, com descumprimento atrelado a consequências negativas, a disciplina do controle interno poderia atingir outro patamar.

De todo modo, a doutrina encontra fundamentos para o controle interno, que serão analisados a seguir, juntamente com as suas funções essenciais (auditoria, ouvidoria,

\footnotetext{
19 Art. 71. No cumprimento de suas finalidades institucionais, o sistema de controle interno abrangerá, integradas entre si, as seguintes funções específicas: I - a ouvidoria, que fomentará o controle social e a participação popular, por meio do recebimento, registro e tratamento de denúncias e manifestações do cidadão sobre os serviços prestados à sociedade e sobre a adequada aplicação de recursos públicos; II - a controladoria, que subsidiará a tomada de decisão governamental e propiciará a melhoria contínua da qualidade do gasto público, a partir da modelagem, sistematização, geração, comparação e análise de informações relativas a custos, eficiência, desempenho e cumprimento de objetivos; III - a auditoria, como instrumento visando a prestação de contas, que avaliará ações implementadas pela administração pública segundo critérios previamente definidos e adequados, com o fim de expressar uma conclusão quanto ao funcionamento de políticas públicas para a gestão responsável e para a sociedade; IV - a correição, que terá a finalidade de apurar os indícios de ilícitos praticados no âmbito da administração pública e de promover a responsabilização dos envolvidos, por meio dos processos e instrumentos administrativos tendentes à identificação dos fatos apurados, à responsabilização dos agentes e à obtenção do ressarcimento de eventuais danos causados ao erário. Parágrafo único. As atividades previstas neste artigo não abrangem a orientação jurídico-normativa da administração pública direta, indireta e fundacional, a cargo dos órgãos de assessoramento jurídico competentes.
} 
controladoria e corregedoria). Neste segundo ponto, urge deixar assente que o cenário exposto nos últimos parágrafos causa discordâncias, já que nem sempre cada função recebe o mesmo tratamento, ou sequer todas existem nos casos concretos. Mesmo com tais limitações, com arrimo nas referências do CONACI, é possível cobrir com objetividade o tema.

\subsubsection{Autocontrole, controle hierárquico e tutela administrativa}

Muito próximo do controle interno, o autocontrole é "a fiscalização exercida pelo próprio agente, responsável pelo ato ou pela atividade, sobre sua atuação" (MEDAUAR, 2014, p. 57). O controle, neste caso, pode ser iniciado por provocação, desencadeado por recursos administrativos quando há apreciação pelo próprio encarregado pelo ato ${ }^{20}$, ou por simples petições de qualquer interessado, com base no direito de petição do art. $5^{\circ}$, XXXIV, “a”, da CF/88.

Porém, pode o autocontrole ser exercido de forma espontânea, pois mais que um poder presente na Súmula 473 do Supremo Tribunal Federal, a autotutela é também um dever, sendo uma exceção à máxima de que ninguém pode fazer justiça por si mesmo (FERREIRA, 2012, p. 141).

É dever da Administração exercer a supervisão de seus atos, no sentido de coibir e corrigir eventuais disparates, de forma célere e com vistas a evitar reflexos negativos àqueles envolvidos com a sua atuação, com destaque à sociedade. Contudo, se tais reflexos forem inevitáveis, cabe à Administração se portar de maneira a prontamente corrigir o ato (ou omissão). (FRANÇA, 2016, p. 102)

Este valor acaba por fundamentar tanto a atuação do próprio agente no controle de seus atos, quanto o controle praticado por outro órgão ou agente da Administração. O vantajoso é que aquele que desempenha alguma atividade administrativa não precisa aguardar que seu superior proceda à fiscalização, pois é possível, e recomendável, que tome a iniciativa de zelar pela regularidade de suas ações, especialmente quando verificar de pronto o descompasso com as normas aplicáveis.

O controle hierárquico, não excluído pelo autocontrole, existe quando há escalonamento vertical dentro da estrutura da Administração Pública. Assim, os superiores, órgãos ou autoridades, fiscalizam os subordinados como decorrência natural de suas atribuições. Segundo Hely Lopes Meirelles, este controle deve estar presente em todos os

\footnotetext{
20 Sobre o pedido de reconsideração como recurso administrativo ver páginas 57-58 da obra Controle da Administração Pública (MEDAUAR, 2014)
} 
órgãos, posto que inerente ao poder hierárquico, base da organização administrativa do Estado, sendo por isso um poder-dever de chefia (2008, p. 679).

Historicamente, o controle hierárquico foi a primeira, e por certo tempo única, forma de controle conhecida. Os príncipes e governantes exigiam que seus subordinados atuassem de acordo com suas instruções, e para isso precisavam de meios para exercício desta vigilância (BRAIBANT; QUESTIAUX; WIENER, 1973, p. 263, apud MEDAUAR, 2014, p. 29-30).

A organização da estrutura administrativa, obedecendo aos parâmetros e competências legais, pode consagrar uma linha hierárquica de coordenação que permite àqueles em posição mais elevada, salvo disposição legal em contrário, analisar amplamente os atos de responsabilidade de seus subordinados, verificando tanto a legalidade quanto o mérito desses para adotar a medida mais adequada ao caso. Com isso, em regra, "o controle hierárquico é pleno (irrestrito), permanente e automático" (ALEXANDRINO; PAULO, 2017, p. 962).

Também são válidos os mesmos comentários traçados sobre o autocontrole, já que o poder hierárquico permite o controle de ofício, tendo a autoridade superior competência para apreciar todos os atos dos subordinados, e a provocação por meio de recursos administrativo é até mais evidente neste tipo de controle, já que, via de regra, endereçados à autoridade superior. Também pode desencadear a fiscalização pelo superior a manifestação de outros órgãos imiscuídos na função de controle, interno ou externo, ou qualquer outra notícia que chegue ao seu conhecimento, mesmo que de entidades não institucionais (MEDAUAR, 2014, p. 61).

Importante ressaltar que a mera existência de mais de um órgão na mesma pessoa jurídica não os fazem escalonados (ALEXANDRINO; PAULO, 2017, p. 962). Assim, nem sempre haverá o escalonamento entre o controlador e o controlado dentro da estrutura em questão. Portanto, o controle pode ser também não hierárquico, onde se destaca a atuação de órgãos integrantes da mesma pessoa jurídica, sem relação vertical, quando há desconcentração para que a função de controle seja especializada (e.g. controladoria ou ouvidoria), além da controversa tutela administrativa.

De plano, tratar a tutela administrativa como parte do controle interno não é unânime na doutrina, mas opção feita neste estudo já foi esclarecida no item 3.2.2.1. Sobre o instituto, Alberto Ramon Real o define muito bem: 
Las personas públicas, ya sea de fin especial o de fines generales, Suelen estar unidas a u gran centro administrativo y político, que mantiene la unidad del sistema, mediante llamada 'tutela administrativa', complejo de autorizaciones, aprobaciones y recursos vários, que cambia según los derechos positivos. (2012, p. 29)

A tutela administrativa, então, consiste no controle exercido pela Administração Direta sobre as pessoas jurídicas da Administração Indireta a ela vinculadas. O cuidado com a utilização da palavra vinculação e não subordinação tem razão de ser: a inexistência de hierarquia nestes casos, que seria decorrente da subordinação, traz importantes peculiaridades para o controle.

A autonomia que é garantida às pessoas jurídicas da Administração Indireta impõe que o controle sobre ela exercido pelo governo central dependa de norma legal. Esta deverá indicar os meios de controle, aspectos a serem controlados, autoridades responsáveis e oportunidades em que o controle será feito, tudo com o escopo de assegurar que a entidade vinculada atue de acordo com as finalidades para as quais foi instituída. Por isso a tutela é também chamada de controle finalístico (ALEXANDRINO; PAULO, 2017, p. 959).

Como é a lei que especifica os objetivos e também a capacidade de autoadministração das entidades descentralizadas, não é permitido ao poder central intervir, quando a lei não lhe facultar tal ingerência, diferente do controle hierárquico que é automático, permanente e pleno. Por isso, a tutela não se presume (ARAÚJO, 2010, p. 1198).

Essa é a tutela administrativa ordinária, que não impede, de forma alguma, a entidade da Administração Indireta de possuir mecanismos próprios de controle interno, que seguem os moldes antes explicados. Contudo, Celso Antônio Bandeira de Mello vislumbra uma tutela excepcional, que foge às regras expostas:

Cumpre observar, entretanto, que a doutrina admite, em circunstancias excepcionais, perante casos de descalabro administrativo, de graves distorções no comportamento da autarquia, que a Administração Central, para coibir desmandos sérios, possa exercer, mesmo à falta de disposição legal que a instrumente, o que denominam tutela extraordinária. (2013, p. 168)

Como observação, em nível federal, art. 26 do Decreto-lei 200/1967 estabelece normas para o controle da Administração Indireta, sem, no entanto, utilizar o vocábulo controle ou tutela, preferindo o termo supervisão ministerial, já que é o Ministro de Estado competente que ficará a cargo desta supervisão (MEDAUAR, 2014, p. 101). 


\subsubsection{Auditoria, Controladoria, Ouvidoria e Correição}

A vigente Constituição Federal prevê sistemas de controle interno nos artigos 31,70 e 74 , mas deixa em aberto quais os componentes desse sistema. Com isso, cada poder ou pessoa política teve a liberdade de estruturar seu controle interno da forma que desejasse, ou quando desejasse em alguns casos. Contudo, algumas figuras foram consagradas na prática administrativa e são frequentemente associadas ao controle, mas sem o devido cuidado conceitual que as distinga.

Neste cenário, a citada Proposta de Emenda à Constituição no 45/2009, que pretende tratar do controle interno em um novo inciso XXIII do art. 37 da Constituição Federal, destaca prioritariamente as funções de ouvidoria, controladoria, auditoria e correição (BRASIL, 2009a). No plano infraconstitucional, o projeto da Lei de Qualidade Fiscal, caso aprovado, traria as definições de cada uma dessas funções (BRASIL, 2016):

- a ouvidoria, que fomentará o controle social e a participação popular, por meio do recebimento, registro e tratamento de denúncias e manifestações do cidadão sobre os serviços prestados à sociedade e sobre a adequada aplicação de recursos públicos.

- a controladoria, que subsidiará a tomada de decisão governamental e propiciará a melhoria contínua da qualidade do gasto público, a partir da modelagem, sistematização, geração, comparação e análise de informações relativas a custos, eficiência, desempenho e cumprimento de objetivos.

- a auditoria, como instrumento visando a prestação de contas, que avaliará ações implementadas pela Administração Pública segundo critérios previamente definidos e adequados, com o fim de expressar uma conclusão quanto ao funcionamento de políticas públicas para a gestão responsável e para a sociedade.

- a correição, que terá a finalidade de apurar os indícios de ilícitos praticados no âmbito da Administração Pública e de promover a responsabilização dos envolvidos, por meio dos processos e instrumentos administrativos tendentes à identificação dos fatos apurados, à responsabilização dos agentes e à obtenção do ressarcimento de eventuais danos causados ao erário.

Tais conceitos estão em consonância com as disposições do CONACI para a matéria (2010), que possuem o mérito de uniformizar as funções para tentar dar aplicabilidade às 
mesmas. A falta de unidade dificulta a elaboração de um sistema verdadeiro, com partes em harmonia que atuem em complemento num mesmo sentido. Apenas para ilustrar a incerteza que paira atualmente, Odete Medauar versa sobre inspeção, auditoria e correição dentro de um mesmo segmento, e deixa transparecer que falta no ordenamento sistematicidade que possa dar concordância nas práticas que envolvem os termos (2014, p. 62-65). Nesse ponto reside o acerto do projeto da Lei de Qualidade Fiscal.

De extrema importância assentar que essas funções não suprimem a importância das procuradorias, conforme expresso no parágrafo único do art. 71 do citado projeto. A orientação jurídica continua sendo essencial, até mesmo para o controle interno, em razão da dificuldade de estabelecer a legalidade em situações limites. Os pareces oriundos dos órgãos de assessoramento jurídico, mesmo desprovidos de medidas, sanções ou vinculação, são formas de controle em sentido amplo.

Mais uma vez a questão municipal deve ser ressaltada, já que nos Estados e na União as procuradorias já estão definidas. O fortalecimento da advocacia pública seria um forte aliado do controle interno, minimizando possíveis influências políticas, já que procuradores de carreira possuem garantias institucionais. Essa percepção, felizmente, já é alvo de deliberação de parte das autoridades competentes, como ocorreu no recente exemplo do Tribunal de Contas do Rio de Janeiro, que determinou a instalação de procuradorias jurídicas próprias em todos os Municípios do Estado, caso ainda não possuam, no prazo de 180 (cento e oitenta) dias, com provimento dos cargos por concurso público (RIO DE JANEIRO, 2018). Portanto, a tendência é que a assessoria jurídica privada fique mais restrita, o que representa um ganho importante para a Administração Pública, com maior estabilidade entre governos.

\subsubsection{Lei Anticorrupção e controle interno}

Neste ponto do trabalho, dizer que o controle interno é significativo é até redundante. Não obstante, com o crescente interesse pela Administração Pública e seus controles, vale acentuar o controle interno como "indispensável à aplicação de políticas gerais uniformes, à emissão de decisões coerentes no âmbito da Administração; e como instrumento de aproximação entre indivíduos e Administração Pública” (MEDAUAR, 2014, p. 56).

Dentro da ideia do controle interno como instrumento, o administrador ou detentor do poder não deve enxergá-lo como contrário a si, como meio de limitação ou criação de obstáculos. $\mathrm{Na}$ realidade, quando bem utilizado, o controle interno permite que o 
administrador conheça sua gestão para proceder correções e ajustes com celeridade, e assim evitar ser surpreendido por órgãos de controle externo quando o ato questionado já causou danos, o que acarreta a penalização do administrador (FERRARI, 2009, p. 203).

Essa atuação do controle interno teve ainda um acréscimo recente, com o advento da $\mathrm{n}^{\mathrm{o}} 12.846 / 2013$, a Lei Anticorrupção, pois os procedimentos administrativos para responsabilização das pessoas jurídicas contarão com órgãos de controle interno, que precisarão estar preparados para tais demandas.

O artigo $8^{\circ}$ da mencionada lei, que contém normais gerais aplicáveis a todos os entes e outras específicas para a União, atribui à autoridade máxima de cada órgão ou entidade a instauração e julgamento do processo administrativo de responsabilização, sendo expressamente permitida a delegação $\left(\S 1^{\circ}\right)$. Também é disposto que, no âmbito federal, a CGU terá competência concorrente para instaurar tais processos, ou mesmo avocá-los para exame ou correção $\left(\S 2^{\circ}\right)$. Em simetria, no Estado de São Paulo, o Decreto n ${ }^{\circ}$ 60.106/2014 disciplina a aplicação da Lei Anticorrupção para seus entes, concedendo mais poder aos órgãos do controle interno.

Nesse sentido, a Corregedoria Geral da Administração, órgão central do Sistema Estadual de Controladoria ${ }^{21}$, detém competência para instaurar e julgar o processo de responsabilização em âmbito estadual (art. $2^{\circ}$, II, “b”), propor a instauração de processos atribuídos à Administração Indireta vinculada (art. $2^{\circ}, \S 1^{\circ}$ ), celebrar acordos de leniência (art. $4^{\circ}$, I) e integrar todas as comissões processantes com no mínimo dois servidores estáveis em atividade na Corregedoria Geral $\left(\operatorname{art} .3^{\circ}, \S 1^{\circ}\right)$.

Em razão das disposições aplicáveis à União, e ao Estado de São de Paulo que adotou regras semelhantes, cumulada com a possibilidade de delegação da competência para instaurar e julgar o processo administrativo de delegação, percebe-se uma tendência de valorização dos órgãos de controle interno para que auxiliem na efetividade da norma, com o modelo sendo difundido por outros entes federativos.

Embora aprioristacamente elogiável a iniciativa, sua efetividade dependerá das condições de preparação dos órgãos de controle interno para absorver demandas complexas como estas, o que é complicado considerando as limitações presentes já para as demandas

21 O Decreto estadual n $n^{\circ}$ 57.500/ 2011 reorganizou a Corregedoria Geral da Administração, institui o Sistema Estadual de Controladoria. 
atuais. Assim, reforça-se a necessidade do fortalecimento do controle interno e integração das atividades nas linhas propostas no capítulo 6.

\subsection{Controle Legislativo, com auxílio do Tribunal de Contas}

Além das modalidades de controle tratadas neste estudo, o controle pode ser também político, que busca manter o equilíbrio entre os Poderes e o funcionamento das instituições democráticas (PEDREIRA, 2013, p. 1093). A finalidade é evitar o crescimento exagerado e domínio de um Poder sobre os demais, e tais freios e contrapesos estão na Constituição, por isso é matéria bem afeta ao Direito Constitucional (CARVALHO FILHO, 2013, p. 939-940). Um exemplo que pode ser utilizado é a possibilidade de veto pelo chefe do Executivo do projeto de lei, e sua posterior apreciação pelo Legislativo, que pode derrubá-lo observando o regramento do artigo 66 da $\mathrm{CF} / 88$.

A explanação é importante pois o controle legislativo (ou parlamentar) possui marcado viés político (FAGUNDES, 1984, p. 88), o que impacta nos limites e na forma do controle. A despeito da obrigatoriedade de observância às normas, em especial constitucionais, que são bem presentes neste ponto, o controle parlamentar nem sempre se restringe à legalidade do ato ou conduta praticada. Na realidade, muitas das previsões envolvem um controle que não é de legalidade e nem de mérito administrativo. Existe assim uma discricionariedade política, que difere da administrativa, respaldada pela Constituição (ALEXANDRINO; PAULO, 2017, p. 987).

Porém, essa influência política na atividade torna o controle parlamentar questionável, já que não condizente com a imparcialidade essencial do controle, além dos limites dos parlamentares sobre assuntos altamente técnicos. Mesmo a doutrina estrangeira identifica o problema:

\footnotetext{
Dado su carácter político y la influencia del régimen de partidos, este contralor de la Administración está muy venido a menos y nunca podría cobrir, em forma sistemática, las necessidades de uma gran administración moderna, cuya complejidad y tecnicismo escapan a la competência y a las possibilidades de trabajo de los parlamentários, absorbidos por su quehacer legislativo y político. (REAL, 2012, p. 30).
}

A descrença sobre o controle parlamentar também é identificada por Odete Medauar, que citando autores estrangeiros demonstra que a despeito de particularidades de cada regime de governo, esta é uma dificuldade comum (2014, p. 105-106), associada a própria 
consolidação e exercício da democracia. Por todos esses motivos, os mecanismos específicos de controle parlamentar não serão abordados.

O controle exercido pelos Tribunais de Contas apresenta melhor prospecto. Apesar de auxiliar no controle externo da Administração, os Tribunais de Contas não são submissos ao respectivo Poder Legislativo, diante da inexistência de relação hierárquica. Seus membros gozam de especiais prerrogativas e ente goza de bastante prestígio na atual Constituição, o que lhe garante autonomia. O tema já foi debatido no Supremo Tribunal Federal, que chegou à mesma conclusão de ausência de submissão (BRASIL, 2009b).

Odete Medauar indaga de forma elucidativa sobre o avanço da atuação dessas Cortes nas últimas três décadas, utilizando como ponto de partida as fortes críticas feitas pelo argentino Agustín Gordillo, para quem esses controles não seriam capazes de alterar a mentalidade e comportamentos, apenas reforçando a formalidade em detrimento da eficácia (2014, p. 124). Como resposta, a autora enfatiza a expansão das competências e condições, garantidas no Brasil pela Constituição de 1988 e pela Lei Complementar nº 101/2009 (Lei de Responsabilidade Fiscal), indicando que os Tribunais de Contas assumiram certo protagonismo dentro do cenário do controle.

Diogo de Figueiredo Moreira Neto expressa uma visão muito positiva no artigo "O Parlamento e a Sociedade como Destinatários do Trabalho dos Tribunais de Contas", por ver na nestas Cortes um aliado na concretude de direitos fundamentais. Vale transcrever um trecho de sua conclusão:

\footnotetext{
Nessa evolução histórica, os órgãos de contas alcançaram indubitavelmente sua maturidade e máxima prestância, deixando de ser apenas órgãos do Estado para serem também órgãos da sociedade no Estado, pois a ela servem não apenas indiretamente, no exercício de suas funções de controle externo, em auxilio da totalidade dos entes e órgãos conformadores do aparelho do Estado, como diretamente à sociedade, por sua acrescida e nobre função de canal do controle social, o que os situa como órgãos de vanguarda dos Estado policráticos e democráticos que adentraram o século XXI. (2005, p. 129-130, grifo nosso)
}

Os artigos 70 e 71 da atual Constituição exprimem uma ampla gama de atribuições específicas, e além do controle de legalidade como princípio geral que já era presente, incluiu a economicidade e legitimidade como valores a serem buscados pelo controle exercido pelo Tribunal de Contas. Em breves palavras, a economicidade é relação entre os recursos empregados e o resultado alcançado, em face do interesse público prometido; a legitimidade é 
um "aprimoramento" da legalidade, conquanto agregue o interesse e a finalidade pública (SIMÕES, 2014, p. 80-81).

Diante do conturbado momento que vive a Administração Pública, os Tribunais de Contas como órgãos de controle não são isentos de críticas, como sobre a influência política que também acomete o controle parlamentar, do qual as Cortes de Contas são auxiliares. A forma de escolha para os cargos de maior hierarquia e dependência orçamentária pode implicar em perda de imparcialidade, o que é agravado pela falha no controle sobre os próprios controladores, tema narrado no item 4.6.3.

Ademais, a pressão do cidadão como destinatário final da atuação do Estado implica na busca por soluções que tornem a prestação estatal mais ágil e eficiente, o que obriga também resposta dos órgãos de controle com maior agilidade e eficiência. Não diferindo dos demais controladores, os Tribunais de Contas precisam estar em sintonia com as demandas atuais, pois não basta o controle correto, que precisa ser célere para atingir seus obtivos, tal como a justiça. O caminho passa pelo uso de instrumentos inovadores, como os de informática e telecomunicações (MILESKI, 2009, p. 111).

\subsection{Controle Judicial}

O fundamento maior para que o Poder Judiciário controle os atos da Administração Pública é o artigo $5^{\circ}, \mathrm{XXXV}$ da $\mathrm{CF} / 88$, que proíbe que até mesmo a lei exclua da apreciação do Judiciário lesão ou ameaça de direito. Com isso, o prejudicado poderá sempre buscar socorro nas vias judiciais, independentemente do responsável pelo dano, até mesmo caso seja ele o Poder Público (DI PIETRO, 2012, p. 810).

O disposto acima consagra o sistema de jurisdição una no país. Em síntese, existem dois modelos de jurisdição que podem ser adotados. No sistema duplo, também chamado de sistema francês, existem órgãos jurisdicionais próprios para apreciar as questões que envolvem a Administração Pública, em qualquer dos polos da demanda, com poder de julgar o conflito em caráter definitivo, sem possibilidade de apreciação posterior por outra jurisdição. Ao contrário, no sistema de jurisdição una, adotado no Brasil, o Poder Judiciário detém o monopólio da última decisão nos conflitos (PEDREIRA, 2013, p. 1091). Mesmo a existência de Tribunais de Contas e outros órgãos de julgamento administrativo não importam em um modelo dual, já que existe a possibilidade de reapreciação de suas decisões pelo Judiciário, ao menos no aspecto da legalidade. 
Sobre o assunto, cabe destacar um ponto. Embora o conhecimento da matéria não possa ser de plano excluído simplesmente por ser afetada à Administração Pública, há limites de cognição sobre os aspectos que podem ser controlados. Assim, o Poder Judiciário sempre poderá se manifestar sobre a legalidade do ato posto em litígio, ou seja, o cumprimento pela Administração das normas que norteiam sua atuação sobre aspectos vinculados do ato, observação de procedimentos previstos em lei, e garantias do administrado inerentes ao sistema jurídico.

Questão mais tormentosa é se a extensão pode atingir o mérito e a discricionariedade administrativa. Mérito aqui entendido como juízo sobre a conivência e oportunidade do ato praticado ou da situação que o embasou, e discricionariedade como a margem de escolha do administrador quanto há mais de uma solução reconhecida pelo ordenamento jurídico, melhor momento para ação, ou possibilidade de agir ou não. Existem assim diferentes correntes, mais ou menos restritas, sobre a extensão da atuação do Poder Judiciário (MEDAUAR, 2014, p. 221).

Esse tema é bastante sensível e discutido no controle judicial de políticas públicas, que são "programas de ação governamental visando a coordenar os meios à disposição do Estado e as atividades privadas, para a realização de objetivos socialmente relevantes e politicamente determinados" (BUCCI, 2002, p. 241). A dotação orçamentaria dos entes políticos não é suficiente para contemplar todos os interesses da sociedade, por isso as políticas públicas dependem de escolhas e renúncias, e aqueles que com elas não concordam buscam o EstadoJuiz.

A base constitucional de algumas políticas públicas é argumento para que o Judiciário exerça um controle mais extenso sobre tais programas, sob alegação de que não haveria violação da separação de poderes neste caso (MOREIRA, 2012, p. 163). Ao cenário é somado o forte cunho principiológico e valorativo da $\mathrm{CF} / 88$, que pauta a atuação do Ministério Público na busca pela garantia do mínimo existencial dos direitos fundamentais, e principalmente a inércia ou atuação ineficiente da Administração Pública, com frequentes casos de corrupção, mau uso dos recursos públicos e decisões guiadas por interesses privados (PEDREIRA, 2013, p. 1092).

Por esse raciocínio, o movimento usualmente chamado de ativismo judicial permite ao juiz que atue de forma ampla, não se limitando a verificar a legalidade ou não do agir administrativo, mas também podendo inovar nas decisões judiciais (PEDREIRA, 2013, p. 
1092). O embate entre ativismo e contenção judicial é bem exposto por Virgílio Afonso da Silva, que se posiciona em corrente intermediária:

\begin{abstract}
Com isso, pretendo sublinhar que a questão discutida neste trabalho não é uma mera questão de opção entre ativismo ou contenção judicial, embora ela seja frequentemente apresentada como se assim o fosse. É certo os partidários da ideia de contenção judicial têm que defender que os juízes devem se manter afastados de decisões relativas a políticas públicas, mas isso não significa que toda a corrente ativista tenha necessariamente que defender o seu oposto, que os juízos devam sempre decidir sobre políticas públicas. Nesse sentido, é possível defender uma forma de ativismo judicial - ou seja, defender que os juízos são legítimos para discutir políticas públicas - e, mesmo assim, sustentar que esse ativismo é limitado por uma série de razões estruturais. (2008, p. 596)
\end{abstract}

O cerne do dilema é encontrar tais limites para a atuação judicial. Não é simplesmente por más práticas que se deve subverter as regras para substituir a ação administrativa da Administração Pública pela vontade do controlador. Ameaçar o equilíbrio entre os poderes ou comprometer todo o planejamento orçamentário do ente federativo são riscos demasiado altos para serem ignorados.

Cuidados devem ser sim tomados, já que o administrador não pode se furtar intencionalmente de qualquer tipo de controle, abusando de impedimentos de forma ou procedimento quando suas ações são antijurídicas. Mas na hipótese da escolha da Administração Pública ser legítima, suficiente e razoável de acordo com direção constitucional e multiplicidade de interesses, ainda que o julgador considere haver melhor alternativa, deve ser respeitada a prerrogativa da Administração como gerenciadora dos recursos públicos (PEDREIRA, 2013, p. 1093).

Nesse sentido cabe analisar a posição do Superior Tribunal de Justiça sobre o fornecimento gratuito de medicamento de alto custo. No Recurso Especial 1.657.156, julgado como recurso repetitivo, o tribunal definiu critérios cumulativos para que o Poder Público seja obrigado a forneceder determinado medicamento fora da lista oficial do Sistema Único de Saúde (BRASIL, 2018). São eles: i) laudo médico atestando que o medicamento é necessário, diante da ineficácia de outro regularmente oferecido; ii) comprovação de incapacidade financeira do interessado; e iii) registro do medicamento na Agência Nacional de Vigilância Sanitária.

O julgado é representativo por franquear a interferência do judiciário em matéria de políticas públicas de saúde, mas com limitações. A decisão segue a linha de que é preciso 
estar diante de uma política pública de índole constitucional para que o controle judicial seja possível bem como é preciso algum ato visivelmente omissivo da Administração Pública. Ademais, tentou-se estalecer critérios objetivos para guiar a atuação de juízes na solução de casos conretos, o que é louvável para garantir isonomia.

Contudo, temas caros à Fazenda Pública não foram amplamente considerados, como a reserva do possível em face de limitações orçamentárias. Quaisquer valores empregados no cumprimento de tais decisões judiciais serão retirados de outras demandas, por vezes igualmente relevantes, o que deveria ser alvo de debate e deliberação social, já que estaria sendo alterada a política de saúde estabelecida pelos representantes eleitos. Logo, a real limitação orçamentária deveria ser um fator obstativo no fornecimento de medicamento de alto custo, o que não foi expresso.

Com essas considerações, somadas àquelas feitas controle de legalidade e mérito no item 3.2.2.2, encerra-se sobre as questões gerais do controle judicial pertinentes ao estudo, sem a pretensão de esgotamento da matéria, como a título de exemplo as formas de controle judicial em espécie, ações cabíveis e procedimentos.

\subsection{Controle pelo Ministério Público}

A valorização dos direitos difusos e coletivos, bem como seus meios de tutela, foi uma das metas da Constituição de 1988. Um dos atores protagonistas neste cenário é o Ministério Público, instituição independente e essencial à função jurisdicional do Estado, o que também vale para o controle da Administração Pública, posto que os interesses em jogo envolvem a sociedade como um todo.

A atuação deste órgão, garantida constitucionalmente com diversas prerrogativas, pode ser cindida nas atuações que envolvem ou não o poder judiciário. Para a atuação judicial são válidos os comentários anteriormente feitos, mas a atuação extrajudicial vale menção própria neste item. Portanto, mesmo que não envolvido na propositura de ações penais ou civis, o Ministério Público é instituição permanente de controle, podendo exigir aclaramentos sobre atividades públicas (FRANÇA, 2016, p. 147).

Independentemente da qualquer formalidade jurídica, o comportamento do Parquet pode fazer com que atos sejam revistos ou corrigidos pela autoridade competente, em razão do poder-dever da Administração de zelar pela legalidade. Contudo, dois instrumentos extrajudiciais merecem ser destacados. 
O inquérito civil possui previsão constitucional no art. 129, III, sendo instrumento exclusivo presidido pelo Ministério Público, cujo objetivo é angariar dados para formação da convicção sobre a prática ou não de alguma irregularidade, bem como avaliar medidas cabíveis para solução. Nota-se que é um procedimento facultativo, que pode subsidiar ou não posterior ação judicial. Na realidade, quando bem utilizado, acionar o judiciário pode se tornar desnecessário caso o próprio inquérito se mostre suficiente.

O outro instrumento de que dispõe o Ministério Público é o termo de ajustamento de conduta, previsto na Lei $n^{\circ} 7.347 / 1985$. Trata-se de um acordo celebrado com o responsável pelo ato ou abstenção questionado, de modo a se adequar ao ordenamento jurídico de modo consensual, evitando assim a discussão judicial da matéria e possíveis penalidades mais severas.

O Ministério Público é essencial para e controle das instituições. Mas seu modo de agir gera consequências no campo do controle da Administração Pública. Phillip Gil França, por exemplo, atesta que o Parquet possui o dever de desconfiar do administrador, e que essa desconfiança garante tranquilidade ao cidadão, sendo própria do regime democrático (2016, p. 151).

Por outra via, esse ceticismo gera presunção de má-fé que prejudica o administrador probo, que no dia a dia da administração gastará tempo precioso para inverter essa descrença automática, além de evitar soluções arrojadas, já que podem desagradar o controlador ensejar repercussões de ordem pessoal para o gestor. Este é um dos desafios que será tratado no item 4.6 .

\subsection{Controle Social}

O verdadeiro titular da res publica é o povo, assim como é também o destinatário natural, mediato ou imediato da atuação executiva, logo deve também ser capaz de proteger os bens públicos colocados sob gestão do Estado. Apesar de manifesto, o controle social passou, e está passando, por significativas mudanças.

A atenção que está sendo dada hoje ao controle social é relativamente recente. Odete Medauar, em sua obra dedicada ao controle da Administração Pública, incluiu capítulo sobre o controle social na edição de 2014, com pretexto de ser um novo controle, sendo que na primeira edição do livro, de 1993, a modalidade não foi abordada, o que foi justificado pela autora pela falta de literatura sobre o tema (2014, p. 185). 
O controle social não foi criado neste mencionado período, mas "tradicionalmente a atividade de controle dos órgãos do Estado e, sobretudo, da Administração Pública tem sido executada num sistema de interface, ou seja, fiscalização das repartições públicas se efetiva por meio dos próprios órgãos estatais" (ALMEIDA; CARVALHO FILHO, 2014, p. 191). O controle, a exemplo da manifestação da vontade popular, seguia o modelo de representação, o que foi considerado insuficiente por setores sociais ávidos por melhoras nas prestações estatais e insatisfeitos com desvios e má utilização dos recursos públicos.

Com isso, surgiram tentativas de controlar a atividade administrativa por via direta, por meio da participação em conselhos, exercício do direito de petição, oferecimento de opiniões e avaliações aos gestores, criação de associações com objeto social voltado à fiscalização da atuação da Administração. Fernando Dias Menezes de Almeida e José dos Santos Carvalho Filho identificam esse impulso como um controle público no sentido de ser aberto a todos, sem restrições de titularidade ou exercício, e não público no sentido de pertencente ao Estado por seus Poderes. Esse é o controle social em expansão (2014, p. 192).

Essa virada contou com a sinergia de diversos atores. A Constituição de 1988 trouxe expressivas disposições sobre a participação popular, como, dentre muitas outras: artigo 37, $\S 3^{\circ}$, sobre o controle social nos serviços públicos; artigo 198, com a diretriz de participação da comunidade nos serviços de saúde; artigo; artigo 204, II, sobre a participação da população nas políticas e controle da assistência social; artigo $31, \S 3^{\circ}$, que torna obrigatória a disponibilização das contas dos Munícipios à qualquer contribuinte; art. $74, \S 2^{\circ}$, que permite a qualquer cidadão denunciar irregularidades perante os Tribunais de Contas; e principalmente o artigo $5^{\circ}$, XXXIII, que garante o direito de todos de receber dos órgãos públicos informações de seu interesse particular ou coletivo, disposição regulada pela Lei o 12.527/2011 (Lei de Acesso à Informação).

Esse rol é meramente exemplificativo e muitas outras previsões são de eficácia limitada, ou seja, necessitam de disciplina legal para que produzam os efeitos desejados. Portanto, os comandos levam tempo a serem absorvidos, regulamentados ou de fato exercidos; mas o caráter programático franqueou o processo de mudança analisado. Ao lado do campo normativo, as mudanças na construção social, impactadas pelo uso das novas 
tecnologias da informação e comunicação ${ }^{22}$, impulsionaram sobremaneira o controle social, já que para controlar é necessário contato.

Mas em que pese a difusão de informações ocorrer em um ritmo nunca antes visto (LEMOS; LÉVY, 2010, p. 52), existem autores preocupados com a qualidade de tais informações e a criação de assimetrias, que podem limitar o controle social e sua expansão, colocando em descrédito seus mecanismos.

A qualidade e a quantidade de informação irão traduzir o tipo e a intensidade da participação na vida social e política. Quem estiver mal informado nem por isso estará impedido de participar, mas a qualidade de sua participação será prejudicada. A ignorância gera apatia ou inércia dos que teriam legitimidade para participar. (MACHADO, 2006, p. 34).

De fato, como antes dito, para controlar é preciso contato, participação e conhecimento. E essa condição é essencial tanto para que haja interesse, como salientado no acima, como para que o controle social não seja desqualificado pelos interessados na manutenção dos atos ou condutas fiscalizadas.

Sobre este segundo ponto, John Rawls tece, mesmo em aspecto teórico e abstrato, considerações sobre a sociedade e o princípio da justiça, apontamentos sobre a participação social que também se aplicam ao controle, como forma participação qualificada:

Todos os cidadãos devem ter meios de informa-se sobre questões políticas. Deveriam ter condições de avaliar como certas propostas afetam seu bem-estar e quais políticas promovem sua concepção do bem público. Além disso, deveriam ter uma oportunidade equitativa de acrescentar à pauta propostas alternativas para a discussão política. As liberdades protegidas pelo princípio da participação perdem muito de seu valor sempre que os detentores de maiores recursos privados têm permissão de usar suas vantagens para controlar o curso do debate público. (2002, p. 246)

O problema da "desqualificação silenciosa", que se exterioriza por condutas que diminuem dados segmentos sociais, em geral camadas fragilizadas, foi exposto por Irene Nohara como empecilho para o controle social e participação popular democrática na gestão da coisa pública (2016, p. 108). Com isso, mesmo que existam oportunidades de manifestação, esses grupos não se sentem legítimos ou capazes de participar em condições de igualdade.

${ }^{22}$ Tema tratado no Capítulo 5. 
Ao reduzir o espectro de atores sociais dispostos a participar, o controle social fica por consequência prejudicado, ou ao menos deixa de atingir seu potencial máximo. Tais posturas discriminatórias não têm como única causa a assimetria informacional, já que impasses culturais complexos são presentes, sendo alvo de discussões de diversas aéreas das ciências sociais, que extrapolam os limites desse estudo. Porém, o fortalecimento do fluxo de conhecimento sem barreiras, voltados para a qualidade do conteúdo, é pressuposto para qualquer ação transformadora.

\subsection{Limites e impasses}

Os problemas administrativos e desvios dos padrãoes esperados, pelo o que se viu, não ocorrem por falta de formas ou mecanismos de controle. Eles existem de forma variada e abrangente, razão pela qual este estudo nem sequer almeja a criação de novos mecanismos. Na realidade a mera previsão de novas regras feitas impulsivamente é apenas outro problema. Contudo, seu funcionamento nem sempre ocorre do modo esperado, e os resultados não são os previstos. Os limites e impasses do controle serão expostos agora.

As dificuldades podem ser divididas já que algumas afetam certas das modalidades de controle em específico, enquanto outras são gerais a toda categoria. Será dada prioridade para os óbices que afetam genericamente a atividade de controle, com considerações pontuais pertinentes.

\subsubsection{Desequilíbrio, duplicidade e sobreposição de trabalhos}

Um primeiro ponto que precisa ser destacado na realidade brasileira é a tendência observada sobre a criação de normas e instrumentos de controle. Em grande medida, a marca da legislação reativa é presente nos microssistemas de controle. Ao reagir imediatamente após casos pontuais de grande repercussão, como meio de acalmar os ânimos da mídia e população, nem sempre as melhores decisões são tomadas. O resultado é a falta de sinergia entre controladores e controlados (MARQUES NETO; PALMA, 2017, p. 22).

A característica da legislação reativa não é um problema exclusivo do controle, contudo essa questão é sensivelmente intrincada no tema, pois a atividade de controle é instintivamente vista como modo de impedir desvios de condutas negativos, que ganham cada vez mais espaço na mídia. E no quadro atual de veloz propagação das informações, a pressão tende a ser mais pungente. Essa pressão é elogiada por ser demostração de um controle social difuso, efervescente, mas que precisa ser canalizado para não forçar medidas imponderadas. 
Não fosse o bastante, Marcos Augusto Perez e Juliana Bonacorsi de Palma destacam o agravamento do problema pela crise de legitimidade que assombra o Legislativo, que então transfere prerrogativas para órgãos de maior prestígio, como são os órgãos de controle, na tentativa de com isso compartilhar parte da confiança neles depositada. Em especial nesse ponto, o Ministério Público figura entre as instituições tidas como mais confiáveis pela sociedade (2017, p. 23).

O que se nota então é um desequilíbrio de prestígio entre controladores e controlados, em especial em relação a alguns órgãos de controle externo, que gozam de grande confiança pela prerrogativa de aplicar sanções severas e atuar de forma rígida. $\mathrm{O}$ atuar de forma severa carrega forte apelo popular, e a sanção pela sanção encontra legitimidade independentemente de suas consequências. Essa instabilidade traz impactos para todos os envolvidos, identificados pelos autores citados.

O primeiro desdobramento identificado é a captura das competências administrativas pelos órgãos de controle. O fortalecimento destes, que isoladamente considerado é benéfico, aliado ao enfraquecimento dos controlados faz com que aqueles órgãos adentrem nas esferas relegadas aos administradores, incumbidos da gestão pública. Mas por mais que os controladores possam ser altamente especializados em suas funções, não são gestores públicos (MARQUES NETO; PALMA, 2017, p. 24-25).

Isso abre margem para voluntarismos, posto que em geral os controladores gozam de autonomia para exercício de suas funções (MARQUES NETO; PALMA, 2017, p. 26). Quando falta orientação institucional forte por parte dos órgãos sobre seus agentes, ou alinhamento entre os diferentes controladores, predileções pessoais podem comprometer a execução de políticas públicas complexas, que envolvam questões multifacetadas.

As normas de controle não costumam prever qualquer proteção ao administrador de boa índole, o que cria um cenário onde parece melhor por vezes escolher soluções que possam agradar o controlador, mesmo que não seja a melhor decisão do ponto de vista gerencial. A preocupação da Administração Pública não pode ser restrita a suprir demandas dos controladores, com transferência indireta de suas competências, mas sim cumprir com as atividades-fim que lhe são impostas (MARQUES NETO; PALMA, 2017, p. 26-28).

Outro problema próximo é a duplicidade ou sobreposição de trabalhos. Tal impasse acaba por agravar sobremaneira o próprio custo do controle, além de prejudicar a 
racionalidade de um sistema de controle eficiente. A escolha desse local para tratar do assunto deriva do fato de que a duplicidade é também uma consequência da falta de sistematicidade oriunda de legislações reativas, desequilíbrio e busca por prestígio, já que faltam fronteiras claras.

O Superior Tribunal de Justiça já foi instado a se manifestar sobre a sobreposição conflituosa de atribuições envolvendo regulação setorial e concorrencial (BRASIL, 2015). No Recurso Especial 1.390.875/RS a corte entendeu deveria ser afastada punição concorrencial por tabelamento de preços, infração à ordem econômica, quando a conduta for determinada pelo Poder Público. Como a atuação dos particulares obdeceu diretrizes setoriais inseridas em uma política específica, sob supervisão estatal, controles de ordem concorrencial seriam afastados.

Mesmo que o caso não trate especificamente do controle sobre a própria Administração Pública, a lição é válida porque a princípio haveria competências conflitantes, mas com base em uma perspectiva lógica uma atribuição teve que prevalecer pelo bem do sistema. Em regra, para evitar tanto o sacríficio de uma forma de controle em detrimento de outra como a sobreposição ou duplicidade, a comuniucação deve ser fortalecida, conforme analisado no capítulo 6.

Em resumo, a falta de integração, comunicação ou delimitação clara de competências pode gerar emprego de controles idênticos sobre o mesmo objeto, desperdiçando os escassos recursos disponíveis, o que será analisado no item seguinte. Não é raro que os impasses se afetem reciprocamente, obscurecendo causas e efeitos.

\subsection{2 $\mathrm{O}$ custo do controle}

O segundo grande limite para que o controle atinja seus objetivos é o custo. A atividade de controle, como qualquer outra atividade estatal, demanda recursos de variados tipos para um bom funcionamento. Dentro de um cenário de limitação, em especial em tempos de crise fiscal, qualquer sugestão que necessite de aporte de recursos precisa passar por diversos crivos, com despesas essenciais básicas tendo prevalência.

No tocante ao controle, os custos envolvem recursos para aquisição e manutenção de estrutura física de suporte aos controladores, além do custo de pessoal, seja para remunerações dos agentes ou para capacitação dos mesmos, já que é uma atividade delicada, com o aperfeiçoamento sendo um mister para que se atingam os resultados esperados. 
O tema é ainda mais sensível quando o controle envolvido é especializado, em que os custos de pessoal são maiores (MARRARA, 2016, p. 63-64). Os agentes são admitidos especificamente para este fim, pertencendo a órgão próprio, com impacto financeiro relevante. E se a pressão por mais controle cresce, diante da limitação humana dos agentes sem que outro fator extrínseco aumente seu rendimento ou os auxilie, para acompanhar a demanda, os gastos também crescerão.

Mas se isto não é novidade, já que restrições financeiras e orçamentárias são limitantes comuns nas atividades, o custo do controle pode ser visto por outro ângulo. Phillip Gil França converte a atividade administrativa no tempo e energia que são dispendidos pela realização da mesma, e em casos de desvios esse tempo e energia seriam desperdiçados:

Ao tratar de corrupção, é válido lembrar que o que torna ilegal a atividade administrativa é o uso do tempo público e da energia estatal para a não realização de benefícios reais para o cidadão. Isso torna o que público, privado, acompanhado de interesse diverso da busca do desenvolvimento intersubjetivo, sempre obrigatório para o Estado. (2016, p. 298)

O controle seria então responsável para assegurar o aproveitamento correto desses recursos, tendo como resultado a maior aplicação de tempo e energia possíveis em prol da coletividade. O problema é que isso conduz a um dilema. A atividade de controle para evitar desperdício de tempo e energia consome para se manter tempo e energia. E mais, sendo a eficiência do controle um resultado de constantes que estão fixas, variando apenas o tamanho da estrutura, para melhorar o controle será necessário um maior gasto.

Esta será então uma decisão alocativa de recursos públicos que implica, em sua outra face uma dimensão desalocativa. Esse pensamento é aplicável tanto na ótica dos recursos orçamentários necessários para manutenção ou expansão do controle, como em sua conversão em tempo. E nas escolhas do administrador, em um cenário de limitação de recursos, esta é uma barreira de difícil transposição.

No limite, como critério para validar o custo do controle, e o tempo como recurso máximo, não se deveria gastá-lo mais com o controle do que seria poupado como resultado. Como solução, resta o avanço da eficiência do controle por meio de outras constantes de produtividade, para que com cada unidade de tempo a conversão em frutos seja maior. Esta não é uma tarefa fácil, mas é o alvo do capítulo 6. 


\subsubsection{Parcialidade e corporativismo}

Uma limitação para o funcionamento ideal da atividade de controle é a proximidade entre o controlador e controlado, quando esta chega ao ponto de comprometer a independência funcional. Embora não restrita esta é uma situação muito mais comum no controle interno, quando não há órgão especializado na função de controle, permanecendo mais hierarquizadas as relações, com riscos de represálias por autoridade superior ou até mesmo revezamento nas posições jurídicas de chefia (MARRARA, 2016, p. 57-58).

Não há como negar que existem influências políticas, econômicas e até mesmo pessoais que incidem sobre os agentes, mas isso não pode comprometer a imparcialidade institucional dos órgãos de controle. E estão sujeitos aos problemas sempre quando houver possibilidade de influência determinante sobre a pessoa do agente controlador, no passado, no presente ou no futuro. O comprometimento gerado atinge tanto a deflagração do processo de controle, impedimento que atos sejam corretamente fiscalizados, quanto o momento decisório, em que nas razões de decidir são considerados motivos alheios ao aspecto controlado.

As noções expostas compartilham bases com outro problema, o chamado corporativismo administrativo, definido muito bem por Thiago Marrara como um:

[m]ovimento de autoproteção dos interesses de classes profissionais dentro da Administração Pública e, em estágio mais avançado, de imunização recíproca de seus membros contra fatores desestabilizadores externos e manutenção de privilégios e benefícios, inclusive pelo sufocamento de instrumentos de controle interno capazes de afetá-los. (2016, p. 59)

O corporativismo também traz como consequência a redução da imparcialidade e prejudica a atividade de controle isenta, mas é distinto por envolver imposições recíprocas entre um conjunto de agentes, que atuam na tentativa de blindar os demais, porque isso implica em uma proteção para si.

Nota-se que essa prática prejudica a atividade de controle quando essa tentativa de resistência ocorre por parte dos controlados, que atuando conjuntamente torna mais penosa a fiscalização, por um instinto de proteção inerente, que acaba agravar o quadro de parcialidade antes exposto.

Fato menos evidente, a falta de imparcialidade e corporativismo também pode atingir os controladores enquanto controlados. Como quaisquer outros grupos, também os 
controladores podem tentar atuar protegendo os interesses da classe, evitando responsabilização sempre que em seus atos desviarem das normas aplicáveis. Afinal, controladores também precisariam ser controlados, ao menos por seus pares na falta de solução melhor.

\subsubsection{Paradoxo}

A visão sobre o controle também é bastante dual. O gestor atribui muito da ineficiência ao excesso ou formalismo do controle, em geral burocrático. Porém, o mesmo gestor pode usar o controle como escudo em escândalos ou para justificar escolhas politicamente incômodas. O cidadão, na mesma linha, questiona o controle quando este se mostra um entrave para obter do Estado as utilidades que almeja, mas exige máxima fiscalização quando desvios são noticiados (SANTOS; BRAGA, 2016, p. 377-378).

Esse último impasse não deixa de ser um reflexo dos demais, já que toda atividade, ainda mais estatal, fica sujeita ponderação de prós e contras quando limites são vislumbrados. Não se discute que o controle é uma função administrativa importante, mas ao se deparar com problemas típicos dessa atividade o caminho simplista é diminuir sua essencialidade, abragência e recursos. A dualidade pode então impactar no próprio modo em que se lida com o controle, facilitando ou impedindo sua expansão de um modo benéfico.

Parte desse antagonismo foi visto recentemente nos debates que antecederam o advento da Lei $n^{\circ}$ 13.655/2018, que acrescentou diversos artigos na Lei de Introdução às normas do Direito Brasileiro (LINDB). O objetivo divulgado foi reduzir a imprevisibilidade e incerteza que a interpretação e aplicação das normas de controle estavam gerando sobre a Administração, aumentando seu custo institucional (SILVA, 2018). A lógica foi tentar inverter pela via legislativa a dúvida que paira sobre aqueles que se relacionam com a função administrativa estatal, conferindo maior segurança, por exemplo, para uma empresa que participa de uma licitação, o que se reflete no preço praticado.

Para exemplificar as alterações que foram de fato introduzidas após sanção presidencial destacam-se os artigos 20, 21 e 22 da LINDB, que pregam: i) a impossibilidade de fundamentar a decisão com base em conceitos jurídicos indeterminados, sem que sejam consideradas as consequências da mesma ou possíveis alternativas; ii) a invalidação de atos, contratos ou ajustes carecerá de motivação expressa sobre consequências jurídicas e 
administrativas; e iii) na interpretação das normas serão consideradas as dificuldades enfrentadas pelo gestor no caso concreto.

Os defensores do espírito da lei se apoiam nos impasses já expostos nos itens anteriores, aludindo que é preciso proteger o gestor de boa índole para permitir que projetos jurídica e socialmente complexos possam ser realizados, pois o administrator não tem segurança para agir, atuando apenas de modo defensivo, o que o conduz à apatia. Outro impacto negativo da incerteza que se buscou mitigar é o aumento dos custos de contratar com a Administração, em razão de tais externalidades (SILVA, 2018).

Por outro lado, muito de questionou a respeito das inovações. A primeira crítica é a falta de debate na condução do processo legislativo, já que a matéria é de extrema relevância e os espaços foram insuficientes, com aprovação repentina. Ademais, o receio dos controladores é que as alterações sejam utilizadas como meio de obstar o controle com fins escusos (BITENCOURT; CAMAROTTO, 2018).

O receio dos controladores externos é justificado, já que os fatos mais recentes agravaram a desconfiança que recai sobre os administradores públicos, responsáveis e interessados pelas medidas propostas. Mas esse medo não pode ofuscar o espírito das alterações, que ataca um problema real do controle e buscar equilibrar controladores e controlados.

De todo modo, a mobilização surtiu efeitos e motivou o veto de um dos dispositivos mais polêmicos. O artigo 25 previa a possibilidade, agora prejudicada, de uma ação declaratória de validade de ato, contrato ou processo administrativo, por iniciativa do próprio ente. Considerando o risco de multiplicação de demandas com esse pretexto e a possibilidade de utilização do expediente para escapar dos órgãos de controle, a decisão pelo veto desse dispositivo e sanção dos demais foi correta.

O controle não deve ser visto como um obstáculo pelo administrador público, diante de sua importância já consagrada. Afinal, o correto funcionamento também é de interesse do gestor. Por outro lado, o controlador também não deve enxargar no administrador um inimigo. Parte dessa dualidade, expressa nos debates sobre a lei em comento, reflete uma polarização que não deveria ser tão marcada. 
Entre erros e acertos, o crucial é que as alterações não sejam apenas novas normas soltas em um sistema disfuncional. Enquanto a conjuntura do controle não for harmonizada, dificilmente essas oposições serão resolvidas. 


\section{AS NOVAS TECNOLOGIAS NA ERA DA INFORMAÇÃO}

\subsection{Conceitos essenciais}

Em uma pesquisa científica da área de humanas, especialmente das ciências sociais aplicadas, ao conduzir o estudo em campo interdisciplinar envolto em outras áreas do conhecimento, é necessário uso de alguns conceitos que são pouco comuns no Direito. $\mathrm{O}$ início deste capítulo será dedicado à exposição de definições importantes que foram aceitas na pesquisa, para que as reflexões futuras possam ser compreendidas, assim evitando digressões. Sem informações de ordem estritamente técnica e que fogem ao escopo da pesquisa, este item trará lucidez àqueles que não são muito familiarizados com o tema.

Para entender o que são as novas tecnologias, existe a necessidade de assentar o que é tecnologia. Tecnologia não envolve obrigatoriamente a informática, telecomunicações ou eletrônica, embora de modo recente essa seja sua característica prevalente. Em outras palavras, sua aplicação envolve tudo o que é criado e aplicado para expandir os limites do ser humano ou facilitar determinada atividade (SILVA; RIBEIRO; RODRIGUES, 2004, p. 81). Em orientação complementar e próxima, Manuel Castells postula que "como tecnologia, entendo, em linha direta com Harvey Brooks e Daniel Bell 'o uso de conhecimentos científicos para especificar as vias de se fazerem as coisas de uma maneira reproduzível"” (2016, p. 87).

Contudo, outros conceitos podem ser encontrados, com diferentes acepções e categorizações conforme estudos avançam. Thiago Marrara, por exemplo, reconhece este ponto e opta por classificar as tecnologias de acordo com a realidade abrangida, sendo elas: as novas tecnologias de saúde, ligadas ao controle do indivíduo sobre o próprio corpo e processos biológicos antes naturais; as novas tecnologias de produção, voltadas para expandir as matrizes de produção, eficiência energética e melhoria dos produtos; as novas tecnologias de transporte, aplicadas na circulação de pessoas e bens cada vez menos custosa e mais ágil e as novas tecnologias de comunicação, tratadas em minúcias oportunamente (2011, p. 227 229).

As tecnologias são separadas para fins didáticos, já que não raro são interconectadas, facilitando as atividades desempenhadas pelas outras. Para ilustrar, o aumento da produção de bens com tecnologias de produção depende para escoamento de soluções de logísticas amparadas em novas tecnologias de transporte. 
Sem pretender excluir a importância do desenvolvimento dos demais setores, para o propósito deste estudo, o controle da Administração Pública, as tecnologias da comunicação foram escolhidas como centro por seu potencial transformador nessa seara. Assim, em geral, quando se utilizar a expressão novas tecnologias se estará referindo deste segmento.

Avançando, dentro deste gênero, as Tecnologias da Informação e Comunicação (TICs), entendidas como o conjunto de computadores, meios de telecomunicações, recursos de mídia e informação por meio eletrônico (KEEN, 1996, p. 15), alteram significantemente a realidade em todos os seus aspectos - sociais, políticos, econômicos e culturais - mas seu uso dentro da Administração Pública, em especial no controle, ainda é incipiente.

Para analisar possíveis contribuições, é necessário antes entender as TICs e sua evolução. Em aspecto mais técnico, Tecnologia da Informação pode ser definida como:

\begin{abstract}
[t]odo e qualquer dispositivo que tenha capacidade para tratar dados e ou informações, tanto de forma sistêmica como esporádica, quer esteja aplicada no produto, quer esteja aplicada no processo.

Como todo e qualquer dispositivo entenda-se hardware, software, firmware ou qualquer outro elemento que permita o tratamento de dados e ou informações de forma cíclica, esporádica, mecânica ou automática. (CRUZ, 2000, p. 24, grifo nosso).
\end{abstract}

Do conceito acima transparece que existe uma distinção entre dados e informações, não devendo os termos serem tratados como sinônimos. "Dado é qualquer elemento identificado em sua forma bruta que, por si só, não conduz a uma compreensão de determinado fato ou situação" (OLIVEIRA, 2002, p. 51). De modo inverso, a informação é o resultado do processamento ${ }^{23}$ dos dados em algo contextualizado, que lhe atribuía significado ou utilidade ao usuário final (O’BRIEN, 2004, p. 13).

Essa distinção é relevante e os vocábulos devem ser utilizados de forma correta. Em um sistema de informação, com suporte de recursos humanos, de hardware, de software e rede $^{24}$, os dados são a matéria-prima dos processos para produção de noções qualificadas para compreensão dos fenômenos alvo (O’BRIEN, 2004, p. 13).

\footnotetext{
23 Processamento "é a ato de transformar o dado em informação pela execução de uma ou de várias atividades eletrônicas" (CRUZ, 1998 p. 62).

24 Para definições técnicas dos termos consultar páginas 11 a 13 da obra "Sistemas de informação e as decisões gerenciais na era da Internet” (O’BRIEN, 2004).
} 
A separação de conceitos inclusive fica mais clara quando se analisa a evolução das TICs, que caminhou no sentido da produção de dados para sua transformação em informações por meio de sistemas, alvo do próximo tópico.

E já aproveitando a abertura, é momento de descrever os sistemas de informação. Apesar dos termos estarem juntos, o conceito de sistema antevê o domínio dos sistemas de informação. De forma genérica, “é um grupo de componentes inter-relacionados que trabalha, rumo a uma meta comum, recebendo insumos e produzindo resultados em um processo organizado de transformação" (O’BRIEN, 2004, p. 07).

Como exemplo há os sistemas biológicos do corpo humano (digestivo, nervoso, linfático, etc.), o conjunto de astros do sistema solar, entre outros. Pode ainda ser que convivam sistemas dentro de outros sistemas maiores. Na mesma linha, Djalma Oliveira compartilha a concepção próxima: "[s]istema é um conjunto de partes interagentes e interdependentes que, conjuntamente, formam um todo unitário com determinado objetivo e efetuam determinada função" (2002, p. 35).

Vários elementos compõem um sistema, dos quais se ressaltam: i) objetivos, sejam dos usuários ou do próprio sistema, constituindo a própria razão do mesmo; ii) entradas, forma de ingresso de recursos materiais, dados, esforço humano e energia para processamento; iii) processo de transformação, que é a conversão do insumo oriunda da entrada no resultado desejado; iv) saídas, que são as destinações dos produtos transformados, cumprindo as finalidades do sistema; v) feedback, o retorno de uma das saídas em forma de dados, produzindo informações sobre o desempenho do sistema; e vi) controle, avaliação do sistema por meio da comparação dos resultados obtidos com as metas estabelecidas a priori, além de indicar e/ou ajustar eventuais falhas (OLIVEIRA, 2002, p. 35-36 e O'BRIEN, 2004, p. 07).

A definição anterior é mais elaborada por O’Brien, ao conceituar os sistemas de informação. O trecho a seguir, além do excelente conceito que traz as TICs para dentro dos sistemas de informação, destaca um ponto muito importante sobre mesmos, que é a sua utilização na comunicação. Com isso, o uso dos sistemas de informação se expandiu de tal forma que deixou o campo acadêmico, militar e empresarial para ganhar toda a sociedade.

Sistema de informação é um conjunto organizado de pessoas, hardware, software, redes de comunicação e recursos de dados que coleta, transforma e dissemina informações em uma organização. As pessoas têm recorrido aos sistemas de informação para se comunicarem, utilizando, desde a alvorada da civilização, uma diversidade de dispositivos físicos (hardware), instruções e procedimentos de processamento de informações (software), canais de comunicações (redes) e 
dados armazenados (recursos de dados). (2004, p. 06, grifo nosso)

Os conceitos expostos até aqui acompanharão o resto do estudo, principalmente a abrangência e sentido dado para as novas tecnologias, que deixaram de expressar apenas a ciência da técnica para representar também o maquinismo resultante (RÜDIGER, 2016, p. $75)$.

\subsection{Evolução}

O desenvolvimento da TICs é fracionado em quatro períodos por Peter G.W. Keen (1996). Inicialmente, na década de 1960, o foco foi o processamento de dados. Nesta época, os computadores começaram a ser economicamente viável em grandes empresas, ainda que bastante caros, mas eram limitados em aplicações e incompatíveis entre si. Os avanços quase sempre eram em hardware, reduzindo seu custo e aumentando a velocidade e capacidade dos equipamentos individualmente considerados. Sendo assim, o uso da tecnologia focou na automatização de processos burocráticos, permitindo ganhos em escala e remodelando a estrutura de pessoal nas empresas (1996, p. 26-28).

Na década seguinte, em meados de 1970, as mudanças tecnológicas começaram a permitir a conversão de dados em informações, além da evolução de sistemas menos rígidos, de acordo com as necessidades gerenciais da empresa. Ainda no período, importante ferramenta foi o terminal de computador, que passou a permitir o acesso flexível, com processamento em "tempo compartilhado". Com isso, era possível realizar várias tarefas ao mesmo tempo, permitindo que mais de uma pessoa trabalhasse em um computador (KEEN, 1996, p. 33-37). Por fim, pela primeira vez linhas telefônicas de voz possibilitaram o acesso a terminais remotos de computadores (KEEN, 1996, p. 26). Caminhou-se no sentido da organização de informações de forma eficaz, e não mera acumulação de dados, evitando duplicidade e facilitando o manuseio.

Na terceira etapa descrita pelo autor, a expansão dos computadores pessoais (PCs) algo que só foi possível com a invenção dos microprocessadores - e softwares de baixo custo, sem necessidade de suporte técnico permanente, possibilitaram o uso da Tecnologia da Informação por um número muito maior de organizações. Com tudo isso, começou a ser possível deixar o viés exclusivo da TI para aplicações administrativas internas e pensar em usos externos voltados ao mercado. Contudo, a despeito das melhorias e das redes locais, os 
computadores ainda eram incompatíveis entre si, dificultando assim a integração dos sistemas e uma maior comunicação (KEEN, 1996, p. 40-47).

A quarta e última fase descrita, na década seguinte tem como ponto chave a compatibilidade. As barreiras que existiam são transpostas e a integração entre as ferramentas e sistemas é total. A troca e acesso a informações passou a ser algo natural e instantâneo, mudando completamente a dinâmica das relações: "[a] TI é reconhecida como fator crítico de capacitação, principalmente através das telecomunicações, que permite eliminar barreiras impostas por local e tempo às atividades de coordenação, serviço e colaboração" (KEEN, 1996, p. 49).

As mudanças narradas foram acompanhadas ou antecedidas pela evolução individual de diferentes componentes e ferramentas que foram sendo inseridos ao longo do tempo e permitiram a integração dos processos. Merece atenção, no entanto, o desenvolvimento particular da Internet: “[n]enhuma outra tecnologia encarna com tanta perfeição a Era da Globalização como a rede mundial de computadores Internet. Ela é o retrato mais fiel do estado da arte em computação virtual (CRUZ, 1998, p. 177)”.

A Internet começou como um projeto para impedir que ataques nucleares acabassem com as redes de comunicação durante a Guerra Fria. Assim, a solução encontrada pelos pesquisadores foi a criação de uma rede de estações de comunicação no lugar das instalações centralizadas existentes até então (MAZZUCATO, 2014, p. 147). Observa-se que a empreitada tinha fins militares e foi financiada pelo governo estadunidense, através da Agência de Projetos de Pesquisa Avançada do Departamento de Defesa (Arpa). Assim, surgiu a primeira rede de computadores, a "Arpanet".

Os primeiros pontos da rede ficaram em Universidades que auxiliavam o Departamento de Defesa, mas os pesquisadores começaram a utilizar a rede para comunicação pessoal, o que expandiu os horizontes da empreitada e a afastou dos fins estritamente militares. Com isso, outras redes foram surgindo, porém todas utilizando ainda a Arpanet como sustentação, que na verdade passou a se chamar ARPA-Internet na década de 80, e depois Internet. Após ficar ultrapassada e encerrar suas atividades em 1990, nova rede assumiu o papel de base da Internet, a NSFNET, da National Science Foundation (CASTELLS, 2016, p. 101). No entanto, o crescimento das redes privadas e a união destas por meio de acordos colaborativos pôs fim a NSFNET, o que privatizou totalmente a Internet, 
embora conte ainda com um pouco de regulação internacional por acordos de endereços de domínios (CASTELLS, 2016, p. 102).

Claro que durante o período os desafios eram enormes e não bastava uma rede de transmissão para permitir que os computadores dialogassem entre si. Para tanto foi necessário um protocolo de comunicação "universal", que todas as redes pudessem usufruir. Após muito trabalho o protocolo TCP/IP (servidor-a-servidor [TCP] e inter-redes [IP]) foi adotado nos Estados Unidos, e acabou vencendo outros concorrentes por sua grande flexibilidade e adaptação, prevalecendo como padrão internacional (CASTELLS, 2016, p. 102-103) ${ }^{25}$.

Desde então o ritmo de mudanças acelerou de modo exponencial em quase todas as áreas econômicas e de tecnologia. A inovação e as novas ferramentas tecnológicas ultrapassaram as fronteiras dos países e a conectividade se tornou completa. O computador, internet e comunicação passaram a ser inseparáveis, relativizando as noções de tempo e distância nos negócios e demais conexões.

O quadro seguinte, elaborado por Francisco Rüdiger (2016, p. 16), expõe cronologicamente marcos históricos da evolução da eletrônica e informática:

$\mathbf{1 9 4 6}$ - Eniac, primeiro computador eletrônico, começa a operar nos Estados Unidos.
$\mathbf{1 9 4 7}$ - A Bell Company começa a substituição das válvulas elétrica pelos transistores.
$\mathbf{1 9 5 0}$ - Alan Turing lança os princípios filosóficos da Inteligência artificial.
$\mathbf{1 9 5 3 / 1 9 5 7 ~ - ~ D e s e n v o l v i m e n t o ~ d a s ~ r e d e s ~ d e ~ t r a n s m i s s a ̃ o ~ d e ~ d a d o s ~ e n t r e ~ c o m p u t a d o r e s . ~}$
$\mathbf{1 9 6 4}$ - Começa a era dos microcomputadores, para uso profissional no trabalho.
$\mathbf{1 9 6 9}$ - Inicio da Arpanet, primeira rede de comunicação por meio de computadores.
$\mathbf{1 9 7 0}$ - A Intel introduz os primeiros circuitos integrados (chips).
$\mathbf{1 9 7 4 ~ - ~ C o m e c ̧ a ~ a ~ e r a ~ d o s ~ P C s ~ ( c o m p u t a d o r e s ~ p e s s o a i s ) , ~ c o m ~ o ~ A l t a i r ~ 8 0 8 0 . ~}$
$\mathbf{1 9 7 5}$ - Bill Gates e Paul Allen começaram a criar programas para computadores pessoais.
$\mathbf{1 9 7 6}$ - Steve Jobs e Steve Wosniak, visando ao mercado não corporativo, criam a Apple
$\mathbf{1 9 8 1 ~ - ~ O ~ I B M ~ P C ~ c o m e c ̧ a ~ a ~ e r a ~ d a ~ c o m p u t a c ̧ a ̃ o ~ p e s s o a l ~ p r o f i s s i o n a l . ~}$
$\mathbf{1 9 8 2 ~ - ~ I n i c i o ~ d a ~ i n t e r n e t , ~ p r o t o c o l o ~ d e ~ l i g a c ̧ a ̃ o ~ e n t r e ~ a s ~ r e d e s ~ d e ~ c o m p u t a d o r e s . ~}$
$\mathbf{1 9 8 4 - ~ L a n c ̧ a m e n t o ~ d a ~ i d e i a ~ d o ~ c o m p u t a d o r ~ c o m o ~ b e m ~ d e ~ c o n s u m o ~ p a r a ~ u s o ~ d o m e ́ s t i c o , ~}$
com o Apple Macintosh.

25 Para evolução mais detalhada da Internet, consultar a obra "A Sociedade em Rede", de Manual Castells (2016). 
Por mais que a ênfase dada por Keen seja a relação tecnologia e empresas, é possível entender pelo percurso como as tecnologias foram se desenvolvendo para atender as demandas comerciais e como às inovações que foram surgindo se adaptaram. $\mathrm{O}$ grau de influência e determinismo entre sociedade e tecnologia é justamente o tema abordado no próximo item deste capítulo.

\title{
5.3 Tecnologia e sociedade: a dinâmica das redes para Castells
}

O início deste item será dedicado à relação entre tecnologia e sociedade no sentido desenvolvimento, ou seja, a predominância de um sobre o outro ao ditar o ritmo das mudanças:

\begin{abstract}
É claro que a tecnologia não determina a sociedade. Nem a sociedade escreve o curso da transformação tecnológica, uma vez que muitos fatores, inclusive criatividade e iniciativa empreendedora, intervêm no processo de descoberta científica, inovação tecnológica e aplicações sociais, de forma que o resultado final depende de um complexo padrão interativo. Na verdade, o dilema do determinismo tecnológico é, provavelmente, um problema infundado, dado que a tecnologia é a sociedade, e a sociedade não pode ser entendida ou representada sem suas ferramentas tecnológicas. (CASTELLS, 2016, p. 64)
\end{abstract}

O excerto chama atenção pela proximidade que o autor coloca a sociedade e a tecnologia, no caso as Tecnologias da Informação e Comunicação, para a sociedade atual, sem que uma subjugue a outra. Existem estudos sobre como ocorre o avanço da tecnologia e inovação (MAZZUCATO, 2014), mas Castells aceita que não é possível prever com exatidão a trajetória de mudanças como em um modelo matemático, mesmo existindo circunstâncias indutoras verificadas em casos passados.

É possível, no entanto, determinar os reflexos sentidos da interação nos padrões da sociedade, caracterizada hoje pela vivência que transcende as noções antigas de tempo e espaço, de onde surge o termo sociedade em rede.

\footnotetext{
A sociedade em rede, em termos simples, é uma estrutura social baseada em redes operadas por tecnologias de comunicação e informação fundamentadas na microelectrónica e em redes digitais de computadores que geram, processam e distribuem informação a partir de conhecimento acumulado nos nós dessas redes. (CASTELLS; CARDOSO, 2005, p. 20)
}

Cumpre salientar que o autor reconhece o uso frequente dos termos sociedade de informação ou do conhecimento, mas não os acha adequados. A justificativa reside na 
constatação de que o conhecimento e a informação sempre estiveram presentes em todas as sociedades, em maior ou menor grau. Não é esta a nota distintiva da sociedade em análise, mas sim o seu modo de organização em redes (CASTELLS; CARDOSO, 2005, p. 20).

O termo rede é empregado por Castells como "um conjunto de nós interconectados. Nó é o ponto no qual uma curva se entrecorta". Concretamente, o autor usa como exemplos os mercados de bolsas de valores, perante a rede de fluxo financeiro global, ou conselhos nacionais de ministros e comissários europeus, sendo nós da rede política que governa a União Europeia (2016, p. 554). ${ }^{26}$

Prosseguindo, em consequência deste modelo de nós, possibilitado pela infraestrutura material das tecnologias da informação, as redes são capazes de se expandir ilimitadamente, conquanto novos nós consigam comunicar-se com os demais, sendo que para tanto devem compartir dos mesmos códigos de comunicação. Havendo essa identidade de objetivos e câmbio de informações de forma fluída, as redes se tornam um sistema aberto, propenso a inovações, sem comprometimento de sua estabilidade (CASTELLS, 2016, p. 554).

E é exatamente a presença ou ausência de rede, bem como a dinâmica de relação com outras redes, que moldará os fluxos de poder, dominação e conformação social (CASTELLS, 2016, p. 553). Com este dado, não é difícil perceber que a capacidade de formação de redes, ou de aproximação com as demais, condiciona a inserção dos atores sociais na lógica global, em um processo de exclusão gradativo para aqueles que falham em tais premissas.

Logo, o avanço das TICs e as mudanças provocadas não são isentos de críticas ou malefícios. Francisco Rüdiger separa os pensadores em dois grupos, conforme a maior ou menor disposição para aceitar que os ganhos das novas tecnologias superam os problemas por elas causados. Os primeiros, prometeicos, identificam na técnica moderna um fator positivo de progresso, com capacidade emancipatória, ou seja, a pesquisa e o desenvolvimento são o caminho para um futuro melhor. O segundo grupo, faústico, bastante crítico, imputa às novas tecnologias a perda de culturas tradicionais, da individualidade e agravamento de desigualdades por apropriação dos benefícios, já que a técnica não seria isenta, servindo sempre a um propósito político ou econômico (2016, p. 51-52).

\footnotetext{
${ }^{26}$ É essa acepção sociológica de rede que será empregada no estudo.
} 
Mesmo Castells, na tentativa de fazer um retrato dessa nova realidade, reconhece que a dinâmica instaurada não rompe com as relações de poder, apesar de deslocar seu centro para novos atores:

Mas a morfologia da rede também é uma fonte de drástica reorganização das relações de poder. As conexões que ligam as redes (por exemplo, fluxos financeiros assumindo o controle de impérios da mídia que influenciam os processos políticos) representam os instrumentos privilegiados do poder. Assim, os conectores são os detentores do poder. (2016, p. 554)

A contextualização foi feita para entender o papel das TICs no contexto atual, sob diferentes aspectos, sem encobrir malefícios. Contudo, em que pesem as críticas, o desenvolvimento tecnológico parece ser um caminho natural e, aparentemente, sem volta (RÜDIGER, 2016, p. 28), portanto é melhor que garantir que os resultados do processo sejam positivos após equacionamento, sem a cegueira de um entusiasmo exacerbado.

Nesse sentido, já aplicado ao objeto mais específico do estudo, interessante pensar em como essa imprevisibilidade na evolução das tecnologias e ampliação das redes pode impactar na utilização das mesmas no setor público. Ao se deparar com um problema, soluções tecnológicas podem ser concebidas, que após funcionamento podem ter seu uso ampliado, em um processo contínuo de aperfeiçoamento. Foi o que ocorreu, por exemplo, com os computadores ligados em rede, pensados para desatar um problema de distribuição de informações, mas que acabou empregado por indivíduos como forma de distração, comunicação e apressamento dos próprios negócios (FEENBERG, 1999, p. 126 apud RÜDIGER, 2016, p. 67).

Aceitando que essa imprevisibilidade atua de maneira benéfica, ao se criar condições para florescimento de redes dentro da Administração Pública, com o emprego racional das TICs, o uso das mesmas poderia também ser aperfeiçoado ao se deparar com problemas anteriores distintos, ou específicos criados no próprio processo. Com isso, as utilidades das novas tecnologias na administração, como no controle da mesma, são, a princípio, ilimitáveis, dada essa característica de dinamismo constante.

E mesmo diante do argumento fáustico de que a expansão das redes e o rumo do desenvolvimento tecnológico são determinados segundo interesses dominantes; a cada etapa de evolução é franqueada a atuação de grupos em redes próprias, com nós próximos aos das demais redes, empoderando-se. Esse processo dialético foi identificado por Castells: quanto 
mais corporações investem para expansão de redes de comunicação, mais as pessoas trabalham em redes de comunicação em massa próprias, adquirindo poder para si (2009, p. $421)^{27}$.

\section{$5.4 \mathrm{O}$ uso da Internet na atividade política}

Ao se perceber o potencial de expansão da Internet nos diferentes setores sociais criouse uma expectativa até mesmo um pouco eufórica sobre seu uso. As mudanças sociais, em especial nas comunicações resolveriam problemas até mesmo de índole democrática, como se expõem:

Esperava-se que a Internet pudesse ser um instrumento ideal para fomentar a democracia (e ainda pode sê-lo). Torna-se muito fácil aceder à informação política através da Internet, pelo que, em princípio, os cidadãos poderiam estar quase tão bem informados como os seus líderes. [...]. Em vez do Governo vigiar as pessoas, as pessoas poderiam vigiar o seu Governo, algo a que deveriam ter direito, já que em teoria o poder reside no povo. No entanto, a maior parte dos estudos e relatórios descrevem um panorama bastante negativo. (CASTELLS, 2007, p. 186).

O trecho transcrito sintetiza muito bem a expectativa criada sobre o poder das novas tecnologias, em especial a Internet, sobre a relação da sociedade com a Administração Pública. Conquanto ainda haja confiança, o cenário comum pode desanimar até mesmo os maiores entusiastas da Internet.

O Estado para seu funcionamento produz, coleta, armazena e precisa distribuir uma quantidade colossal de informações, dificilmente comparada com qualquer outro agente privado. Na realidade, em razão da criação e aplicação, por vezes forçada, de regras, a gestão de informações pelo Estado é bastante complexa, adquirindo caráter simbólico (BREGA, 2015, p. 17). Portanto não há como dissociá-lo do contexto informacional descrito anteriormente.

Ocorre que um canal de comunicação mais intenso com a sociedade em geral somente se desenvolve próximo do período eleitoral (CASTELLS, 2007, p. 188), quando parece ser mais conveniente explorar qualquer recurso capaz de atingir o maior número de pessoas, no resto do tempo o fluxo informacional é mais burocrático. Mas a oposição evidente de interesses entre candidatos e partidos para vencer o pleito coloca em dúvida a credibilidade da

\footnotetext{
${ }^{27}$ No original: "And so, there is a dialectial processes that I documented in Chapter 2, and analyzed in terms of its political manifestations in Chapter 5: the more corporations invest in expanding communication networks (benefiting from a hefty return, the more people build their own networks of mass self-communication, thus empowering themselves" (CASTELLS, 2009, p. 421).
} 
abundância de dados e informações postos no período, o que dificulta, sobremaneira, a análise para fins de controle.

A falta de uma estrutura permanente com uso efetivo até possui justificativas. O ponto mais óbvio é a necessidade de investimento (BREGA, 2015, p. 21), seja para aquisição ou desenvolvimento de equipamentos e softwares informáticos, seja para treinamento de servidores, que nem sempre geraria os resultados esperados, dada admissível resistência dos sujeitos, por envolver questões culturais mais amplas, ligadas ao próprio contexto de inserção de dado indivíduo ao contexto das novas tecnologias.

Mas a base para todas as justificativas é a menor propensão da Administração para correr riscos. É totalmente compreensível que a iniciativa privada aceite com mais facilidade a possibilidade de fracasso, e também pode oferecer maiores prêmios por êxito, pois não sofre as restrições da indisponibilidade do interesse púbico. O impacto na velocidade de adoção de mudanças é natural (BREGA, 2015, p. 23-24).

Essas desculpas, contudo, não podem afastar a necessidade de adesão pela Administração Pública da revolução tecnológica, mesmo que de forma gradual. Do contrário, o Estado ficará sujeito a um processo de distanciamento por deixar de refletir a realidade que lhe fundamenta e que regula, podendo chegar ao ponto de se questionar a própria necessidade de uma estrutura como tal.

A Internet, instrumento representativo das novas tecnologias, é vista sim como um meio de libertação, mas como uma moeda de dois lados distintos, tem em sua face oculta um grande poder de exclusão. Como seu uso garante inúmeras possibilidades e vantagens, aqueles que não se inserem na lógica informacional ficam excluídos das relações de transformação dos negócios e da sociedade, desvalorizados pelos que conduzem o processo (CASTELLS, 2007, p. 317).

Esse pensamento se completa muito bem com a lógica exposta na dinâmica das redes de Castells, conforme consta no item anterior. O autor afirma que a distância, que representa a qualidade e velocidade de interação, varia conforme os pontos sejam integrantes da mesma rede ou nós de redes distantes. Isto é, entre dois pontos em que convergem os fluxos de informações a distância seria zero se estes pertencerem a mesma rede. O afastamento é sempre maior quando não se trate de nós e de redes diversas, até o limite do infinito para pontos externos (2016, p. 554), que seria a completa exclusão. 
Essa constatação é de extrema relevância para o estudo proposto. A necessidade de inserção da Administração Pública na morfologia da rede para funcionamento ótimo e integração já foi expressa. Mas, para organização do controle, essa lógica é essencial. A formação de uma rede de controle, onde os atores se organizem em nós, com distância mínima entre eles, é o que permitirá que o controle acompanhe as atividades que se presta a controlar. De igual modo, os nós da rede de controle devem estar próximos, ou até mesmos serem compartilhados, com nós de redes conexas, para que o fluxo de informações e integração seja máximo.

Para ilustração do conceito, diga-se que as formas de controle social, legislativo, judicial e interno são nós de uma rede de controle funcional. Por serem da mesma rede, a distância entre eles é zero. Neste caso, em dado ente federativo, a função administrativa também segue a morfologia da rede, tendo o controle interno também como nó. Como consequência, toda a Administração Pública estaria muito próxima da rede de controle, que funcionaria sem isolamento e sem sobreposição, um dos problemas apontados no capítulo anterior.

Mas para ser fiel ao tema do uso da Internet na política, uma última consideração precisa ser feita. Não é possível mais negar que a ferramenta tem impacto nos processos eleitorais, pois, como já salientado, nesses períodos é que a estrutura política garante mais atenção à comunicação direta os eleitores (CASTELLS, 2007, p. 188). E dentro da tendência de expansão da influência das novas tecnologias é questão de tempo para seu protagonismo também em termos eleitorais.

A preocupação do Superior Tribunal Eleitoral nesse sentido confirma a hipótese, preocupação esta expressa na Resolução n. 23.551/2017, diploma com normas sobre propaganda eleitoral, horário gratuito e condutas ilícitas para as eleições deste ano. A Resolução contém um capítulo próprio (entre os artigos 22 e 35) para tratar apenas de propaganda eleitoral na Internet, em um indício de seu destaque.

A discussão central que deve guiar os responsáveis é como controlador o conteúdo sem incidir em censura, já que a liberdade é uma das virtudes mais felicitadas e caracterísitica inerente da Internet. Por isso a própria Resolução visa resguardar a liberdade de expressão, afirmando em seu artigo 33 que a atuação da Justiça Eleitoral em relação aos conteúdos se dará com a menor interferência possível no debate democrático. 
Contudo, esse valor precisa ser contemporizado com o prejuízo também democrático que as notícias falsas causam em um ambiente de fácil reprodução como a Internet. O limite entre a liberdade de expressão, "verdades" populares não confirmadas e notícias com cunho prejudical é tenuê. Este um dos desafios que será enfrentado no pleito que se aproxima, já que o judiciário será chamado para decidir o que deve ou não ser admitido, além dos critérios do controle. Novos rumos podem surgir para a relação Internet e política.

\subsection{Perspectivas futuras - a ciberdemocracia de Pierre Levy}

Manual Castells é um grande expoente e referência no assunto da sociedade no contexto informacional, razão pela qual sua obra é um marco para trabalhos no assunto (WEBSTER, 2006, p. 98). Contudo, diversos outros autores se debruçaram sobre como a tecnologia interage com os atores sociais, alguns claramente mais otimistas do que outros.

Na tentativa de antecipar os próximos passos da revolução tecnológica e seus impactos, Pierre Levy traz importantes ensinamentos, que muito bem complementam o objeto deste estudo. O autor é um grande entusiasta das novas tecnologias, para o qual o momento não é de criticar os erros de percurso, mas sim corrigi-los (RÜDIGER, 2016, p. 159). Essa visão positiva é útil para entender a dimensão e o potencial das novas tecnologias, e assim fixar um objetivo de interação destas com a sociedade, mesmo que ainda longe da realidade atual.

Das obras do autor, merece destaque o livro "O futuro da internet", pois nele é dado maior espaço para as relações com o poder público e exercício da política pelo cidadão em um contexto informacional (LEMOS; LÉVY, 2010). Permeia por todo texto que a reconstrução da geografia territorial através da nova comunicação social, realidade que cria o denominado ciberespaço, suaviza a distinção do público e privado, de um modo benéfico para a democracia.

E a linha otimista é bem explicita desde o começo, sendo reconhecido que a obra é um exercício de utopia. Com base na investigação do presente, e na evolução até o momento, busca-se pensar o futuro (LEMOS; LÉVY, 2010, p. 21). Mas enquanto o resultado final é um ideal, a premissa do pensamento é uma realidade inegável: a presença implacável da Internet aproximando espaços e pessoas, a invasão das novas tecnologias nos mais diversos setores e a conectividade sendo um atributo natural e permanente. 
A partir desse ponto, os autores aceitam que essa realidade permite um pensamento mais colaborativo e aberto. E "quanto mais podemos livremente produzir, distribuir e compartilhar informação, mais inteligente e politicamente consciente uma sociedade deve ficar” (LEMOS; LÉVY, 2010, p. 27).

A expressão cultural, a valorização e soma das inteligências individuais não é algo inédito da sociedade atual, mas o ciberespaço ofereceu a maximização sem precedentes da liberdade de construir e emitir pensamentos, já prontamente sujeito a aceitação ou revisão pelos receptores. Os integrantes do ciberespaço são produtores, consumidores e controladores dos conteúdos em circulação. Nas palavras de Lemos e Levy, “[p]odemos dizer que entramos em uma época onde a democracia e o ciberespaço vão se engendrar mutuamente em um círculo autocriativo e global" (LEMOS; LÉVY, 2010, p. 55).

Como resultado, ao aplicar os conceitos no campo político, surge o conceito da ciberdemocracia, compreendido no seguinte trecho: "[a] ciberdemocracia é um tipo de aprofundamento e de generalização das abordagens de uma livre diversidade em espaços abertos de comunicação e cooperação" (LEMOS; LÉVY, 2010, p. 54).

Isso não significa que a cada nova tecnologia inserida, ou a cada nova conquista de mídia, como preferem os autores, implicará em um novo regime político, em pensamento que muito se adequa ao exposto em item anterior. Não há esse determinismo direto; contudo, e esse ponto é essencial, algumas mudanças dependem de mídias apropriadas para ser implementadas, ou sequer concebidas no plano teórico (LEMOS; LÉVY, 2010, p. 60).

A constatação ocorre, em grande parte, pela tendência de que toda a produção humana atinja grau de dispersão universal. Prosseguem os autores dizendo que gradativamente os signos sociais, fluxos de pessoas e informações, debates, anseios e contradições serão conhecidos em tempo real, com elevado grau de transparência (2010, p. 64).

A facilitação do fluxo de informações é o caminho natural, o que por si só não implica em garantia de atingimento de um estado de equilíbrio e atingimento de capacidades coletivas de forma equânime. A obra, contudo, atenta muito para esse ponto:

Deve-se temer um novo totalitarismo? Sim, mas devemos pensar também que a transparência generalizada à qual nos dirigimos tende a se tornar simétrica. A liberdade de expressão e o acesso à informação aumentam para todo mundo e não apenas para os Estados e as grandes empresas. [...]. O totalitarismo se caracteriza igualmente pelo caráter vertical e unidirecional dos fluxos de informação onde as comunicações horizontais, transversais, livres e abertas são proibidas; onde as informações vêm da população, as ordens e a propaganda descem do poder. No 
entanto, vemos que o tipo de comunicação tornada possível pelo ciberespaço é o exato oposto da configuração totalitária. (LEMOS; LÉVY, 2010, p. 60).

Portanto, elencando estágios de desenvolvimento, num primeiro momento, as TICs potencializam a soma das inteligências individuais, de modo que a estabelecer e mobilizar uma consciência coletiva. Por sua vez, a demanda por diálogo e transparência atinge de forma inarredável a administração pública. Alfim, com os espaços físicos sendo ainda mais relativizados, a politização atingirá nível de coordenação global, com as comunidades encontrando vínculos que as unam. Este é o caminho para a ciberdemocracia planetária ${ }^{28}$.

Por evidente que esta etapa global de integração não está próxima, não sendo sequer afirmar que tal progresso assim ocorrerá (LEMOS; LÉVY, 2010, p. 40-41). Mas nem por isso as considerações feitas devem ser excluídas, já que ao menos úteis como guia para as relações da administração com a sociedade, mídias, tecnologias e comunicação, talvez até como um parâmetro de correção em caso de desvios.

E aplicando o raciocínio no escopo do estudo, a pressão da sociedade para maior transparência e controle do Estado já é uma realidade. Sendo assim, a utilização de novas tecnologias, responsáveis pelas transformações sociais que culminaram nesse ponto, é um imperativo lógico para o controle da Administração Pública.

\footnotetext{
${ }^{28}$ O capítulo 8 do citado livro trata especificamente da globalização e da ciberdemocracia planetária, inclusive sobre seu possível funcionamento e instituições relevantes (LEMOS; LÉVY, 2010, p. 157-178).
} 


\section{INTERAÇÕES DOS CONTROLES E NOVAS TECNOLOGIAS}

Este último capítulo é dedicado a analisar as formas de integração dos controles no sentido de que se tornem mais eficazes e eficientes, isso dentro da sociedade atual moldada pelas novas tecnologias. A mera indicação no texto constitucional de que existirá um sistema de controle não foi capaz até o momento efetivar o mesmo na prática, dados os impasses já narrados.

Assim, é necessário perquirir qual caminho a ser percorrido para melhores resultados, primeiro em perspectiva teórica, e após extraindo informações de uma aplicação tecnológica real.

\subsection{Controle sistêmico ou rede de controle?}

A Constituição Federal usa a expressão sistema de controle em alguns pontos, como já citado anteriormente, que pode ser entendido como uma determinação de que os controles não sejam isolados ou voltados para si mesmos. Sendo assim, construções nesse sentido não são necessariamente novidades, mas a forma de trabalhar o assunto para melhores resultados não é única.

Evandro Martins Guerra foca no compartilhamento de informações e articulação entre os órgãos em forma piramidal, com o controle social e interno na base, e o controle externo no topo (2008, p. 10). Para o autor, esse arranjo ensejaria o controle sistêmico, idealmente exprimido pela seguinte ideia:

\footnotetext{
A forma sistêmica de controle exige que todos os elementos componentes estejam organizados logicamente, interligados pelo ordenamento jurídico mediante dispositivos constitucionais e legais, de maneira a facilitar o desencadeamento das atividades fiscalizatórias e corretivas. As partes do sistema, quer dizer, os sub-sistemas (social, interno e externo) devem se inter-relacionar visando ao funcionamento da estrutura, combinando meios e procedimentos que culminem na produção de certos resultados. $(2008$, p. 10)
}

O mais interessante é que da abstração não se cria um novo tipo ou mecanismo de controle, mas tão somente um conceito de organização para tornar mais eficientes os institutos existentes. Contudo, o foco do autor foi mais atender ao decidido na Carta Maior e evitar duplicidade de trabalhos (GUERRA, 2008, p. 11), que não deixa de ser um revés, do que compatibilizar o controle com as necessidades da sociedade e Administração Pública no contexto informacional. 
Talvez o controle sistêmico seja um estágio idealizado de desenvolvimento e não propriamente um modo de aproximação dos controles. Esta é uma percepção já que não são dados subsídios para chegar a esse nível. O ideal certamente é integrar, por própria determinação constitucional, mas como na prática essa integração não ocorre prontamente, soluções, ao menos hipotéticas, precisam ser dadas.

Por outra via, seria possível pensar nos controles da Administração Pública inseridos na lógica das redes, expressa no Capítulo 5. A nova morfologia social obedece à estrutura das redes; os impactos das novas tecnologias na integração dos mais diversos campos são nítidos, portanto, a mesma lógica pode ser aplicada ao controle da Administração Pública.

Nesse sentido existe até mesmo uma iniciativa interessante em andamento no país que começou em 2009, a Rede de Controle da Gestão Pública. Em sua página oficial, consta a seguinte explicação sobre o conceito, os objetivos e estratégia para atingi-los:

A Rede de Controle é um centro decisório interorganizacional, que visa aprimorar a efetividade da função de controle do Estado sobre a gestão pública. A Rede tem como principal objetivo o desenvolvimento de ações direcionadas à fiscalização da gestão pública, ao diagnóstico e combate à corrupção, ao incentivo e fortalecimento do controle social, ao compartilhamento de informações e documentos, ao intercâmbio de experiências e à capacitação dos seus quadros.

Para atingir esse objetivo, a estratégia adotada é a de ampliar e aprimorar, de modo expresso e efetivo, a articulação de parcerias entre os órgãos públicos e as entidades, nas diversas esferas da Administração Pública, mediante a formação de rede de âmbito estadual e federal, bem como a interação da rede formada pelos signatários do acordo estadual com a Rede de Controle da Gestão Pública. ${ }^{29}$

Deste empreendimento foram signatários diversos órgãos institucionais de controle, como a Advocacia-Geral da União, a Controladoria-Geral da União, o Ministério Público Federal, o Tribunal de Contas da União, O Conselho Nacional de Justiça, o Banco Central, o Senado Federal, a Câmara dos Deputados, diversos Ministérios e associações representativas de outros órgãos de controle.

Portanto, existe uma tentativa oficial por parte dos próprios controladores institucionais e outros órgãos públicos de articular uma rede de controle. Não é a mera previsão em um documento que efetiva a produção, processamento e difusão de informações através de nós conectados, mas o protocolo trouxe a preocupação em fixar ações iniciais por

\footnotetext{
$29 \mathrm{Na}$ página oficial da rede é possível encontrar também o inteiro teor do protocolo assinado, todos os signatários e demais acordos firmados desde 2009. Disponível em: <http://www.rededecontrole.gov.br/rede-decontrole/inicio.htm>. Acesso em 05 de maio de 2018.
} 
meio de: oficina de trabalho, com foco em ações conjuntas; soluções em tecnologias da informação; projetos de capacitação; entres outros, sendo um importante ponto de partida para inserção na lógica das redes.

Deve-se também notar que existe preocupação em formar e integrar redes em diferentes âmbitos, com vários outros acordos estaduais e setoriais firmados, todos disponíveis para consulta no mencionado sítio eletrônico. Cabe pontuar que nos acordos de cooperação técnica firmados no âmbito dos estados participam como signatários entes federais - Ministério Público Federal, Advocacia-Geral da União, Procuradoria da Fazenda Nacional, favorecendo a formação de nós de concentração e propagação de informações.

Comparando com a ideia de controle sistêmico, a inserção dos controles na morfologia das redes, a exemplo das redes de controle da gestão pública, parece mais adequado posto que o Estado deve refletir em maior medida possível o arranjo social vigente. Outrossim, a rede é uma estrutura mais pronta para lidar com os impasses do controle da Administração Pública, conforme se verá.

\subsection{Novas tecnologias e redes de controle}

Já assentada a premissa de que a rede é o ideal para o controle da Administração Pública, faz-se necessário trilhar o caminho para atingir esse estágio, e principalmente destacar o papel das novas tecnologias nesse cenário, que foram determinantes na construção da sociedade em rede.

Manuel Castells elucida muito bem o nível de determinismo da tecnologia na formatação de uma organização em rede. A tecnologia é condição essencial para tal, mas ao mesmo tempo não é capaz de sozinha chegar ao resultado esperado. E nas palavras de Castells, "a tecnologia é condição necessária mas não suficiente para a emergência de uma nova forma de organização social baseada em redes, ou seja, na difusão de redes em todos os aspectos da atividade base das redes de comunicação digital (CASTELLS; CARDOSO, 2005, p. 17).

Essa consideração chama atenção para a incapacidade das novas tecnologias serem responsáveis, isoladamente, por moldar a organização social ou atividades. Certamente são instrumentos capazes de transformação, mas é preciso que essa transformação seja conduzida para algum fim. A sociedade em rede, descrita no Capítulo 5, foi resultado de uma série de fatores. 
Logo, a formação de uma rede de controle da Administração Pública prescinde da aplicação de novas tecnologias pelos controladores em suas atividades. A tecnologia é o substrato essencial para nutrir os fluxos de informação que se estabelecem entre os agentes da rede. Também é a tecnologia que tornará possível a ampliação da capacidade de coleta, armazenamento e processamento de dados para torna-los úteis ao controlador. Mas sozinha não é o bastante.

A recepção das novas tecnologias pelos atores envolvidos é que determinará o sucesso ou fracasso na formação de redes funcionais. Afinal, antes que um canal aberto e contínuo de comunicação seja estabelecido, é decisão dos órgãos e agentes permanecerem isolados. Isto pode ser superado caso seja situação pontual, com o gradual distanciamento dos controladores resistentes, mas quando a coletividade se comporta dessa forma fica difícil colher bons resultados.

A importância do aspecto cultural resta então elevada. Neste ponto alterações normativas e iniciativas por acordos institucionalmente vinculantes são muito felicitadas, por serem aptas a moldar ou induzir comportamentos. Por essa razão o protocolo de intenções para criação da rede de controle da gestão pública é bastante oportuno.

Ou seja, em um cenário em que o controle interno for fortalecido pela adoção das medidas sugeridas no item 4.1 , bem como as competências dos controladores sejam bem delimitadas, pela lei ou pela prática, a adoção de novas tecnologias pode encontrar um universo propício para estabelecer as conexões necessárias.

Neste ambiente serão franqueadas a continua expansão e surgimento de outras tecnologias e aplicações, específicas para o uso desejado. Não é sequer possível limitar de antemão o alcance da rede, que com o tempo e superação de problemas vai se especializando.

Atingido o objetivo da organização em rede, os benefícios são numerosos, como já explorado de modo difuso pelo trabalho. Ainda assim, vale menção algumas características, positivas, identificadas na estrutura reticular, que justificam a adoção do modelo em boa parte dos negócios no século XXI (GOLDSMITH; EGGERS, 2006, p. 46).

A primeira delas é a possibilidade de aproveitamento da especialização dos diversos agentes componentes da rede (GOLDSMITH; EGGERS, 2006, p. 47). O rompimento de barreiras geográficas garante que cada ator possa se dedicar aos seus fins institucionais, já que 
as atividades podem ser facilmente complementadas por integrantes da rede, sem que isso signifique, por outro lado, compartimentalização isolada de atividades.

A morfologia das redes permite, ou melhor, incentiva a experimentação, que aliada ao contato com múltiplas ideias, favorece o ambiente inventivo (GOLDSMITH; EGGERS, 2006, p. 49). Também propiciam inovações as respostas dos destinatários dos serviços disponíveis, já que a avaliação permite contato com os pontos a serem corrigidos, ponto este de singular importância no tocante a Administração Pública, já que suas atividades são em grande parte destinadas à população.

Outra característica das redes é a maior velocidade e flexibilidade, principalmente quando comparada com uma estrutura hierárquica burocrática (GOLDSMITH; EGGERS, 2006, p. 50). Mesmo que a Administração Pública nem sempre possa usufruir de tamanha flexibilidade, diante de necessárias amarras legais, é útil estar inserido em uma estrutura que faculte mais elasticidade, como em momentos de crise, pois assim é mais fácil lidar com falhas.

A rede é uma organização aberta que permite expansão ilimitada caso novos nós compartilhem meios de comunicação com os demais (CASTELLS, 2016, p. 554), o que representa um alcance crescente em termos de atuação, impacto e até mesmo captação de recursos financeiros (GOLDSMITH; EGGERS, 2006, p. 53-55). Novos parceiros e fontes de financiamento são essenciais para lidar com as demandas cada vez mais complexas que surgem.

Essa adoção em modelos de negócios é pensada por ser mais eficiente do ponto de vista produtivo e econômico, mas que não são os únicos critérios em jogo quando o assunto são interesses coletivos e difusos. Ocorre que as vantagens não ficam restritas nesse campo justamente pela flexibilidade das redes, sendo possível colher frutos a depender do escopo que é dado.

No limite, as redes permitem, com o amplo uso das novas tecnologias, a ampliação do número de atores sociais atuantes em dada atividade. Para os parâmetros deste estudo, essa constatação é de alto impacto, já que o número de produtores e interpretes reflete a pluralidade de interesses na sociedade, basilar para o exercício da cidadania, que ocorre em mais espaços de interação. 


\subsection{Benefícios das novas tecnologias no controle da Administração Pública}

$\mathrm{O}$ item anterior explorou as características positivas do modelo reticular como forma de justificar e explicar seu uso, que somente foi viabilizado pelas novas tecnologias. Para dar completude ao papel das mesmas, no entanto, é preciso focar no seu emprego no controle da Administração Pública.

O título desta seção pode conduzir a uma ideia errada de que o uso de TICs pelo poder público em suas atividades inerentes, não limitadas ao controle, é irreprovável ou isento de complicações. Infelizmente, adaptar as atividades do Estado dificilmente são assim simplistas, e não se quer aqui cometer esse erro. O primeiro ponto que precisa ser destacado é que o Estado estabelece relações internamente e com particulares, e isso é relevante na introdução de novas tecnologias (MARRARA, 2011, p. 232-233).

Nas relações do Estado em que envolva os cidadãos as tensões entre objetivos organizacionais e garantias fundamentais ficam mais patentes. A introdução de novas tecnologias não pode conferir um poder desmedido ao poder público ou torna-lo indiferente, apenas subjugando os sujeitos. Um dos exemplos é o conflito de valores na manipulação de dados pessoais por entidades públicas, que coloca em campo a transparência ou publicidade e a necessidade de preservação da intimidade, inviolabilidade da honra e privacidade.

Essas questões são alvos de enfrentamento e precisam ser equacionadas já que as novas tecnologias são realidade na prática administrativa ${ }^{30}$. O alerta serve para ponderar também o aspecto negativo que acompanha a maioria das decisões, mas que é bem minimizado no que tange às relações para o controle da Administração em comparação com os benefícios, já que os efeitos da "ingerência" são por ela sentidos. Assim, não se sacrifica bens individuais de valor intangível dos administrados. Como enuncia Marrara,

O papel das novas tecnologias para a superação dessas dificuldades é impressionante. De um lado, as tecnologias de comunicação, telecomunicação, rádio, internet etc. colaboraram com a facilitação do acesso a dados, quer pela criação de formas simples, rápidas e baratas de criação de documentos digitais, digitalização de documentos físicos e transferência de arquivos, quer pelo aprimoramento de ferramentas de busca de dados e informações em documentos digitais ou digitalizados de acordo com o interesse específico do órgão controlador.

[...] Hoje, com o uso de novas tecnologias, o mapeamento de indícios de irregularidade e ilegalidade no exercício da atividade administrativa e a tomada das respectivas medidas corretivas podem ocorrer de modo muito mais rápido, célere e

\footnotetext{
30 Sobre o tema, a obra "Governo eletrônico e direito administrativo" (BREGA, 2015) explora muito bem as nuances do ato e processo administrativo eletrônico, como detalhes sobre requisitos de validade e vícios dos mesmos.
} 
barato, sempre de acordo com os interesses do órgão controlador e a despeito de sua atuação presencial. (MARRARA, 2011, p. 244-245)

Nesta via, é possível notar que as vantagens se contrapõe em grande medida com os impasses expostos no item 4.6. A facilidade de comunicação e registro permite que o gestor de boa-fé comprove mais facilmente suas intenções para com a legalidade e o interesse público. Assim, a desconfiança natural que recai hoje sobre os administradores poderia ser reduzida, para que ao menos a presunção de legitimidade pudesse vigorar, como pretendeu a recente reforma da LINDB. Restaurar a confiança nos administradores públicos é essencial para reduzir o desiquilíbrio entre controlador e controlado, permitindo que o controle seja mais efetivo e eficiente.

Outro ponto que merece destaque é a possibilidade de coordenação entre os próprios controladores. Foi dito que com as gamas de prerrogativas, e voluntarismos dos controladores, é comum a sobreposição de trabalhos, o que é ineficiente do ponto de vista da alocação de recursos. As TICs permitem que ações conjuntas sejam mais facilmente realizadas, e o contato instantâneo cria condições para o compartilhamento de informações, evitando atuações isoladas idênticas.

Prosseguindo, um grande aliado para garantir a impessoalidade da ação administrativa é a execução por softwares inteligentes automatizados, já que isentos concepções pessoais, sentimentos e variações de comportamento normais da natureza humana. O uso dessas tecnologias limita a parcialidade, já que as respostas são programadas e qualquer tratamento favorecido ficará visivelmente demonstrado. Os desacordos entre a solução padrão e o desfecho do caso serão facilmente percebidos e acessados.

Existem casos em que o desacordo com a solução padrão deve ocorrer, pois situações excepcionais pedem medidas condizentes. Não é possível a extrema rigidez. Por isso a decisão final permanecerá com a autoridade competente, cabendo a ela, motivadamente, dar tratamento ao caso concreto de forma diversa do que programado, quando houver necessidade. Porém, essa prerrogativa será usada com maior parcimônia, pois o próprio controlador estará sob controle.

Também sobre o problema dos custos do controle as novas tecnologias podem influir positivamente, em especial quando se entende o custo como tempo da administração. Com a equação de produtividade do controlador fixa em função da estrutura, as novas tecnologias 
podem ser elemento que desequilibre o sistema para que ele se estabilize com em ponto de maior eficiência. Com as mesmas variáveis - número de agentes, insumos materiais, tempo disponível, mas com a diferença da aplicação das TICs - é possível obter mais controle, em quantidade e qualidade.

Isso ocorre porque a capacidade de processamento torna os dados em informações mais rapidamente, prontos para uso; perde-se menos tempo com comunicação e acesso a documentos físicos e arquivos; e principalmente tira do agente o peso cognitivo de decisões corriqueiras, realizadas automaticamente, assegurando mais tempo e energia para questões de relevância (ROVER, 2001, p. 248 apud RAMOS JR; ROVER, 2006, p. 04).

Paralelamente, as tecnologias do transporte reduzem o custo para permitir que o controlador tenha a apreensão física, presencial, do ato ou de efeitos que precisam ser controlados. Este é, sem dúvida, um benefício que auxilia na atividade de controle sem um preço anexo a ser pago. Ocorre que até mesmo esse ponto já começa a ser superado por novas iniciativas, como será analisado no caso prático da Plataforma de Acompanhamento de Licitações Públicas. Logo, por mais que seja mais barato se locomover até o local de interesse, em algumas hipóteses a necessidade de deslocamento do agente é suplantada por soluções de tecnológicas e sistemas de informação.

Por certo que implantar o aparato tecnológico e treinamento contém em si um gasto, mas que por alterar permanentemente a equação de produtividade, tais gastos devem passar com tranquilidade pelo crivo da economicidade, já que "ao mesmo tempo, esse estímulo à legalidade é realizado a custos significativamente menores que outrora” (MARRARA, 2011, p. 245).

Diante desses benefícios, até mesmo a visão sobre o controle pode não enfrentar mais tanta dualidade. Com a sua otimização, deixa de ser justo atribuir embaraços em ações executivas com base no controle, já que a fiscalização e critérios procedimentais podem ser mais ágeis. Quem sabe assim a atividade de controle será compatibilizada com os valores da segurança jurídica, tão caro aos gestores públicos.

\subsection{Análise da Plataforma de Acompanhamento de Licitações Públicas}

Os benefícios expostos podem até parecer utópicos, mas talvez não estejam assim tão longe da realidade. As mencionadas transformações tecnológicas ocorridas nas últimas 
décadas eram no início irrealizáveis, o que não impediu os avanços em diversos campos. Não há razão para desacreditar que isso não possa ocorrer no setor público.

O arcabouço teórico construído viabiliza dar espaços para que ideias se concretizem, e será com experiências práticas que as deduções serão comprovadas. Justamente para demonstrar como toda esta teoria encontra aplicação, este item irá analisar uma plataforma muito criativa e funcional, que concretiza muitas das aspirações narradas e possui enorme potencial.

A Plataforma de Acompanhamento de Licitações Públicas (PALP) é uma iniciativa nascida com objetivo de propiciar mais transparência em contratos de licitações, em especial as contratações que envolvam obras públicas, pois a exteriorização do objeto contratual nestes casos é de mais fácil percepção pela população. Com layout intuitivo e acessível a todos, a ferramenta permite a integração da sociedade com os controles da administração, com o uso das novas tecnologias.

Em relato presente no respectivo sítio eletrônico ${ }^{31}$ é possível conhecer a gênese e os responsáveis pela plataforma:

Desenvolvida em novembro de 2016, durante as 24 horas do Hackathon-USP eGovernance, a plataforma, neste mesmo evento, venceu como melhor solução em transparência combate à corrupção. No mês seguinte, a PALP foi escolhida como um dos projetos do I Edital Santander/USP/FUSP de políticas públicas, sendo contemplada com recursos financeiros para o desenvolvimento da plataforma.

Atualmente, a plataforma conta com o apoio da Nexos Gestão Pública - Grupo de Cultura e Extensão da FEA-RP/USP - e do GPublic - Centro de Estudos em Gestão e Políticas Públicas contemporâneas - e possuí obras do munícipio de Ribeirão Preto e do Campus da USP Ribeirão Preto cadastradas, disponíveis para fiscalização.

O nascimento da plataforma foi fruto de uma reunião de condições propícias com um bom capital humano empreendedor, algo bastate alinhado com outras inovações verificadas no campo das tecnologias da informação e comunicação. A feliz diferença foi a aplicação específica ao controle da Administração Pública.

Em razão do seu princípio e idealizadores, já que o dialógo é facilitado, as primeiras experiências foram no munícipio de Ribeirão Preto, no próprio campus da Universidade de São Paulo. A plataforma no início era um protótipo desenvolvido no evento Hackathon-USP

\footnotetext{
${ }^{31}$ No endereço eletrônico é possível encontrar as informações, além de acessar a plataforma. Disponível em: $<$ https://palp.com.br/>. Acesso em 21 de maio de 2018.
} 
e-Governance, sem todas as funcionalidades que são hoje observadas com o avanço do projeto. Ao lado do melhoramento foram adicionados novos parceiros, sendo que outros entes públicos aderiram ao projeto.

Conforme consta do Lab FGV Brasil Inovador, a PALP está inserida dentre iniciativas de inovação sujeitas a parceria ${ }^{32}$. Assim, os custos e prazos já estão publicamente descritos para todos que desejem implementar o mecanismo. É possível que qualquer ente administrativo contrate a PALP, o que pode fomentar sua expansão em um período já próximo.

Explicando em linhas gerais a plataforma, após seu correto desenvolvimento, ao acessá-la é possível visualizar a interface do Google Maps, que é bastante conhecida. Neste plano são colocados em destaque ícones que indicam a localização de obras públicas em execução ou recentemente finalizadas. Ao selecionar um dos ícones, ficam disponíveis diversas informações, como: tipo da obra, status, valor do contrato, prazo de execução, aditamentos e justificativas, modalidade da licitação, empresas participantes e propostas, valor inicialmente orçado e dados da empresa vencedora. Neste mesmo local existe espaço reservado para fotos e comentários que podem ser inseridos livremente pela população, para que seja feito o acompanhamento da execução do contrato ${ }^{33}$.

A navegação pela plataforma é bastante intuitiva e simples, apesar da boa quantidade de ferramentas. Para facilitar o uso, são liberados filtros para selecionar a cidade de desejo e o tipo de obra (reforma, construção ou revitalização), além de legendas para os ícones, franqueando acesso mesmo para aqueles não acostumados com aspectos técnicos sobre contratações públicas. Como últimos destaques, em outras abas, a PALP contém ainda informações gerais sobre licitações e um ranking das empresas que mais participaram de licitações, com contratos vencidos e valor médio.

Após o contato com a PALP facilmente se percebe seu potencial para o controle da Administração Pública. Um dos objetivos declarados de fomentar o controle social pode ser atingido justamente pela plataforma ser prática, gratuita e acessível, sem impor qualquer barreira para quem tenha acesso à Internet.

\footnotetext{
32 As informações sobre a PALP, dentro do Brasil Inovador, podem ser acessadas em: <http://labfgv.com.br/brasilinovador/2017/palp-plataforma-de-acompanhamento-de-licitacoes-publicas/>. Acesso em 21 de maio de 2018.

${ }^{33}$ Exemplo vide Anexo I.
} 
Esse é o grande chamariz da plataforma. Contudo, com um olhar mais profundo, seu potencial vai muito além de incluir a população no acompanhamento de obras públicas - o que já seria ótimo. Por exemplo, no caso de obras é comum haver a necessidade de verificação dos controladores no local para atestar as informações prestadas documentalmente. A plataforma tem condições de mitigar essa carência, considerando que já serão remotamente oferecidos subsídios para a fiscalização, com fotos e outros detalhes inseridos pela sociedade em campo aberto.

Assim, o uso da plataforma pelos controladores garantiria uma nova fonte de informações atualizadas, sem gasto de tempo para vistoria e de recursos financeiros. Por mais que as tecnologias de transporte tenham reduzido os custos com locomoção, a economia é ainda maior quando a apreensão do objeto controlado pode ser feita a distância.

A iniciativa é incipiente, depende ainda de contratação pelas pessoas jurídicas responsáveis pelos contratos. Mas pelos dados já lançados na plataforma nesse pequeno período de existência é verificável que os orçamentos estimados foram observados, não havendo indícios de fraudes ou sobrepreço nas licitações até o momento acompanhadas, o que já é significativo.

Essa característica de ferramenta auxiliar do controlador deve ser explorada pelo controle interno, por instruções próprias, para que o gestor público conheça em tempo real o andamento fático das obras pelas quais é responsável, ou eventualmente seja corrigido quando for necessário. Esse é o uso inicialmente visado, porém não é o único, pois a plataforma pode também instruir o controle externo, por parcerias ou convênios.

Órgãos de controle externo, como Tribunais de Contas, podem adotar a PALP como instrumento de fiscalização complementar, e basear suas decisões nas informações do sítio eletrônico. Verificações de rotina fazem parte dos procedimentos de controle, mas podem ser reduzidos, além do contraditório ser mais efetivo quando os atores usam modo idêntico de apreensão da realidade nas discussões jurídicas.

O mesmo pode ser afirmado sobre o uso pelo Ministério Público, que possuirá mais um meio de fonte probatória para cumprir seu papel, inclusive sem demandar trabalho do administrador para fornecer as informações, previamente disponibilizadas. O cidadão é outro capaz de acionar os meios de controle institucionalizados ou se mobilizar de forma difusa 
diante de irregularidades antes apenas especuladas, mas que agora estarão visíveis. Este é o ponto de revelo das TICs, sua grande abertura para diferentes funcionalidades.

Novo aspecto que ganha revelo é a vigilância permanente que a plataforma cria sobre os próprios controladores. Uma vez sedimentando seu uso, a atividade do controlador será também acompanhada, já que os fatos estarão expostos. O controle social munido de dados objetivos e de qualidade é um modo idôneo de evitar o corporativismo, voluntarismo ou subjetivismo dos agentes.

Esse cenário em uma primeira análise parece colocar ainda mais pressão sobre o administrador público, que já sente o peso da decisão neste clima de incerteza e o controle seria mais incisivo. Não obstante, essa não é a única leitura. A plataforma protege o gestor de boa-fé na medida que propicia um registro público e transparente que milita como prova das condições em que se tomaram as decisões e seus desdobramentos no caso concreto.

A PALP é uma inovação que, como já salientado ser característica das novas tecnologias no decorrer do estudo, pode desencadear novos usos e aplicações. Novas funções são passíveis de serem incorporadas: além do ranking de empresas que mais participam de licitações, fica a sugestão de que a plataforma sincronize dados de doações eleitorais feitas pelos sócios destas empresas, para que o controle social seja ainda mais amplo, e permita agregar no desenvolvimento da democracia brasileira, ainda carente de fontes seguras no que tange informações de interesse público passíveis de distorções para fins eleitorais.

E mais: a organização da ferramenta e o fluxo de informações franqueado muito se adequa aos ditames da rede, modelo almejado para funcionamento das atividades de controle. A integração dos controladores em formato de rede é facilitada quando existe armação material adequada, que incentiva a dispersão dos centros produtores de informação e decisão, mantendo, contudo, coesa a estrutura.

Portanto a plataforma não inaugura uma rede de controle como exposto no item anterior, mas sua aceitação permitiria reuniar condições para caminhar nesse sentido de integração. O espírito inovador é uma boa aposta para induzir mudanças estruturais e até comportamentais consistentes, mas é feito o aviso de que o grau de sucesso depende da colaboração dos administradores, da população e outros orgaõs de controle.

A PALP, surgida em ambiente universitário, demonstra como soluções inventivas surgem e podem redefinir dadas funções, representando o melhor do uso das novas 
tecnologias na Administração Pública. Nos próximos anos será possível saber se a plataforma atingiu todo seu potencial, contribuindo efetivamente no controle. 


\section{CONCLUSÕES}

As funções da Administração Pública atingem hoje todos os campos de interesse, da educação à segurança nacional, da saúde ao fomento de atividade de pesquisa, das telecomunicações à assistência social, da garantia do direito de propriedade à defesa do meio ambiente, dentre tantas outras. Ainda que de forma sazonal influências neoliberais possam reduzir uma ou outra função, alterando um pouco o tamanho do Estado, as demandas continuarão intensas.

A própria doutrina diverge sobre os rumos futuros no que tange a configuração estatal (ARTS; GELISSEN, 2010, p. 579-580). Transformações são naturais e dificilmente um modelo de Administração será perene; o que existe é um núcleo de funções que são essenciais, sobre as quais não há como retroceder.

Aceitando então essa ampla gama, não se pode esperar que todo o conjunto de ações possíveis de serem adotadoas seja minuciosamente previsto de forma anterior pelo legislador, sendo necessário garantir ao administrador campo para atuação. $\mathrm{Na}$ realidade, nem é recomendável que o legislador fique a cargo da disciplina total de quaisquer minúcias administrativas, já que grande parte é de caráter técnico, e o agir do gestor envolve decisões alocativas que precisam de análise global, por envolver escolhas em cenário de restrição.

Em paralelo a esta liberdade, como consequência natural, o controle da Administração Pública ganhou força para atuar em um ambiente de constantes mudanças. O controle, com diferentes acepções semânticas, costuma exprimir as noções de fiscalização e correção, mas como o juízo de conformação não é mais mecânico, os controladores precisam de meios de auxílio para corresponder aquilo que deles se espera, já que a tarefa é excessivamente árdua.

A noção de controle evoluiu no tempo, mas os processos utilizados na atividade de controle não acompanharam a velocidade das transformações das atividades controladas, em especial no setor público, que possui característica rigidez. Com essa afirmação não se pretende dar espaço para a prática da legislação reativa, que se mostrou prejudicial no cenário do controle brasileiro.

Mesmo neste emaranhado legislativo, não é contraditório afirmar que, no tocante ao controle interno, a normatização é bem-vinda. Particularmente nesta espécie, falta tanta uniformidade prática que imposições legais, claras e pensadas, podem surtir bons resultados. 
Como segundo ponto, quando é dito que o controle precisa ser lapidado se pretende exteriorizar seus efeitos para acompanhar o volume de recursos e complexidade das ações sujeitas ao controle, que aumentaram em grande escala. E esta tarefa é factível, desde que pensada e em sintonia com as próprias mudanças sociais que refletem na demanda do Estado.

O fenômeno humano não pode ser entendido fora de seu diálogo com a tecnologia. Nada está transformando tanto a realidade humana como a tecnologia em todas as suas facetas. Os conceitos de natural e de artificial se sobrepõem e se complementam continuamente. (BUSTAMANTE, 2010, p. 13)

A sociedade e todas as relações não podem mais ser entendidas em um contexto isolado, alheio à realidade das novas tecnologias, que construíram um novo paradigma desde o final do século passado. O dinamismo obtido, em grande parte, com as tecnologias da comunicação e informação alterou as relações de trabalho, poder, econômicas e simbolismo cultural.

Nesta pesquisa, foi delimitado o âmbito do termo novas tecnologias, mas que adquiriram uma amplitude conceitual enorme, condizente com o aumento de sua presença na realidade. Não pode ser esquecida a capacidade de inovação dentro desse meio, o que pode exigir constantes atualizações sobre o alcance do termo por parte dos pesquisadores.

Como as funções da Administração Pública refletem a sociedade na qual está inserida, não é concebível que o gestor dos interesses públicos esteja alheio aos propulsores de transformações do meio em que está inserido. É preciso ao menos uma paridade para que o múnus público seja bem realizado, que só será obtida quando os mesmos instrumentos tecnológicos estiverem disponíveis e em uso.

O controle da Administração é um tema complexo que acompanha as conjunturas históricas de uma dada sociedade ou Estado. O controle meramente prévio como realizado mostrou-se burocrático e lento. O controle posterior não consegue sempre remediar os efeitos das irregularidades, além de pecar no caráter de prevenção no cometindo de infrações. A saída pensada neste estudo foi utilizar as condições materiais hoje existentes para fortalecer a mescla de controles instantâneos e contínuos, superando distinções tipológicas, para que estas sejam tão somente classificações acadêmicas.

O modelo reticular, descrito por Manuel Castells conforme item 5.3, domina as organizações emergentes e não há razão para que não seja aplicado aos sistemas de controle 
da Administração Pública, que em muitas vezes falham em pontos nos quais os benefícios das redes são mais acentuados, como: especialização das funções sem necessidade de duplicidade de trabalhos, em face da integração e cominucação facilitada; apreensão de dados fáticos e sua propagação de forma célere e com baixo custo; e redução de desvios em razão da parciliadade, induzindo o efeito preventivo de todo bom sistema de controle.

O mesmo pode ser dito sobre o uso das novas tecnologias para aplicações no controle, já que essas constroem para a formação de redes e também são instrumentos de aplicação direta em muitas das atividades principais ou auxiliares dos controladores. Munidos de instrumentos e suporte apropriados, o rendimento particular de cada agente pode crescer para assim atender melhor a demanda, sem comprometer demasiadamente a celeridade ou onerar os cofres públicos com estruturas gigantescas de controle. A alteração da equação do controle é medida a ser buscada para superar o modelo atual.

Não é demais lembrar os perigos atinentes ao distanciamento entre os instrumentos e organização da Administração Pública em relação ao utilizado no restante da sociedade. A falta de sintonia já é sentida e tende a piorar se não houver algum ajuste de rota. A similitude, por outro lado, gera de confiança e previsibilidade, já que nos é compreensível o que é usual, mitigando o afastamento que existe hoje em relação ao funcionamento da Administração Pública.

Ainda mais grave, os ativos tecnológicos estarão disponíveis para todos que deles puderem se apropriar, inclusive com objetivos pessoais em prejuízo da coletividade. O grande alcance é uma carecterística importante das TICs, ampliando efeitos positivos ou negativos. Ou seja, não bastasse perder a oportunidade de usufruir dos benéficios de conexão das redes, não incorporar as novas tecnologias deixa o Estado e a sociedade sujeitos a instabilidades, em razão do desnível. Tais prejuízos não são restritos às atividades administrativas comuns, podendo atingir até mesmo o processo democrático ao criar disparidades que não podem ser contidas por falta ferramentas de igual alcance, passando o falso como verdadeiro.

Na conjugação das análises dos itens 6.2 e 6.3, percebe-se correlação entre os ganhos em tese com os impasses do controle narrados ao final do Capítulo 4. Não há como fazer um juízo de certeza para dizer que as novas tecnologias resolverão na prática todos os problemas do controle, mas no plano teórico as soluções se encaixam. 
Nessa linha, e em complemento, a Plataforma de Acompanhamento de Licitações Públicas demonstra a aplicabilidade efetiva dos conceitos, confirmando, ainda que de forma tímida, a hipótese. De uma iniciativa estudantil, sem dispor de um enorme volume de recursos, foi possível adotar uma ferremanta que vai de encontro com muitos dos impasses usuais do controle. O potencial em caso de expressiva aceitação é empolgante.

Os efeitos benéficos da organização em rede e das novas tecnologias são convincentes, e exatamente por isso podem ser incômodos para os que se aproveitam de situações de descontrole, ou que temem mudanças que os forcem a sair de uma zona confortável. As novas tecnologias criam de fato uma necessidade de aprendizado constante que força a todos, agentes e estruturas, se colocarem em movimento.

O instinto protetivo coletivo e o medo do desconhecido formam uma barreira cultural de difícil transposição na Administração Pública, já que sua grande estrutura é menos adaptável. E os agentes políticos, que detém maior poder decisório, não atuam energicamente em prol das novas tecnologias:

É por isso que de facto os governos são ambíguos em relação aos usos da Internet e das novas tecnologias. Eles apreciam os seus benefícios, porém temem perder o controlo da informação e da comunicação em cujo poder sempre se apoiaram. (CASTELLS; CARDOSO, 2005, p. 29).

O sentimento dividido que assola tais segmentos precisa ser gradualmente trabalhado, pois a tendência de expansão das novas tecnologias não pode ser ignorada por muito tempo. A imposição do meio aliado com pleitos informados da sociedade, ciente desse potencial positivo, coloca a Administração Pública sob pressão. E é melhor que existam balizas teóricas para nortear o desenvolvimento quando ele ocorrer.

Caso seja necessário escolher um lado entre os otimistas ou céticos em relação às novas tecnologias, com os devidos cuidados, melhor seguir a primeira linha. Neste cenário fluído e incerto, um pouco de confiança é útil para que a transição, inevitável, corra no sentido desejado. O trabalho buscou oferecer subsídios para quem deseja implementar o uso de novas tecnologias no controle da Administração Pública, ou para que as cobranças da sociedade nesse sentido sejam orientadas.

Por mais utópica que seja a ideia de uma ciberdemocracia planetária nos termos narrados por André Lemos Pierre Levy (2010), o fortalecimento da participação e controle 
social pode ser muito antes alcançado. Os ganhos de publicidade, processamento, acesso e transparência atrelados às novas tecnologias são provas disso, que corretamente articulados incluirá em nós muito próximos a sociedade, controle e Administração Pública.

Talvez a maior virtude seja justamente essa, a viabilidade de integrar os controles, em sua acepção mais ampla, para que a distância entre eles tenda a zero. A lógica das redes, que permite esse arranjo de espaços mínimos (item 5.4), possibilita também o fluxo de informações no mais alto patamar com outras atividades estatais.

Espera-se que este arcabouço teórico possa auxiliar os responsáveis por tomada de decisões relevantes, para que as escolhas sejam informadas e motivadas. Um bom teste para acompanhar a visão sobre Internet e política se dará nestas eleições, com a preocupação do Tribunal Superior Eleitoral sobre o tema, o que pode influcier acontecimentos futuros sobre novas tecnoligias e o controle da res publica.

Do que se propôs nesse estudo, esclareceu-se sobre a inserção das novas tecnologias da sociedade e seus reflexos no controle da Administração Pública, como base teórica para que essa implementação seja feita de forma racional. No mais, a análise da experiência da PALP permite infirmar que as novas tecnologias podem exercer o benéfico papel que delas se supõe, havendo também outras plataformas, aplicativos ou softwares buscando atingir objetivos semelhantes. Em um futuro próximo grandes melhorias poderão ser vistas. 


\section{REFERÊNCIAS BIBLIOGRÁFICAS}

ABRÚCIO, Fernando Luiz. O impacto do modelo gerencial na Administração Pública. Cadernos Enap. Brasília, $\mathrm{n}^{\mathrm{o}} 10,1997 . \quad$ Disponível em: <http://repositorio.enap.gov.br/handle/1/556>. Acesso em: 17 de março de 2018.

ALARCÓN, Pietro de Jesús Lora. Ciência política, Estado e direito público: uma introdução ao direito público de contemporaneidade. São Paulo: Verbatim, 2011.

ALEXANDRINO, Marcelo; PAULO, Vicente. Direito Administrativo descomplicado. 25. ed. Rio de Janeiro: Forense, São Paulo: Método, 2017.

ALMEIDA, Fernando Dias Menezes de; CARVALHO FILHO, José dos Santos. Tratado de Direito Administrativo. Vol. 7 - Controle da Administração Pública e Responsabilidade do Estado. São Paulo: Revista dos Tribunais 2014.

ARAÚJO, Edmir Netto de. Curso de Direito Administrativo. 5. ed. São Paulo: Saraiva, 2010 .

ARTS, Wil A.; GELISSEN, John. Models of the Welfate State. In: CASTLES, Francis G. et al. (Ed.). The Oxford Handbook of The Welfare State. Oxford: Oxford University Press, 2010.

BALBE, Ronald da Silva. Controle interno no Brasil: uma visão histórica. In: BLIACHERIENE, Ana Carla; BRAGA, Marcus Vinicius de Azevedo; RIBEIRO, Renato Jorge Brown (coords.). Controladoria no setor público. Belo Horizonte: Fórum, 2016, p. $37-60$.

BITENCOURT, Rafael; CAMAROTTO, Murillo. Dodge recomenda vetos ao PL sobre funcionamento de órgãos de controle. Valor Econômico, online, 23 de abril de 2018. Disponível em: <http://www.valor.com.br/politica/5476049/dodge-recomenda-vetos-em-plsobre-funcionamento-de-orgaos-de-controle>. Acesso em: 10 de maio de 2018.

BONAVIDES, Paulo. Teoria Geral do Estado. 9. ed. São Paulo: Malheiros, 2012.

BRASIL. Plano Diretor da Reforma do Aparelho do Estado - Documentos da Presidência da República. Brasília: Presidência da República, Câmara da Reforma do Estado, Ministério da Administração Federal e Reforma do Estado, 1995. Disponível em: $<$ http://www.biblioteca.presidencia.gov.br/publicacoes-oficiais/catalogo/fhc/plano-diretor-dareforma-do-aparelho-do-estado-1995.pdf>. Acesso em: 18 de junho de 2018. 
. Senado Federal. Proposta de Emenda à Constituição $n^{\circ}$ 45, de 2009. Acrescenta $o$ inciso XXIII ao art. 37 da Constituição Federal, dispondo sobre as atividades do sistema de controle interno. Disponível em: <http://legis.senado.leg.br/sdleggetter/documento?dm=3467265\&disposition=inline >. Acesso em: 06 de abril de 2018.

. Senado Federal. Substitutivo ao Projeto de Lei do Senado no 229, de 2009. Altera dispositivos da Lei de Responsabilidade Fiscal ( $\operatorname{LC~}^{\circ}$ 101/2000) e revoga a Lei $\mathrm{n}^{\circ}$ 4.320/64. Disponível em: <https://legis.senado.leg.br/sdleggetter/documento?dm=3931964\&disposition=inline >. Acesso em: 06 de abril de 2018.

. Supremo Tribunal Federal. Ação Direta de Inconstitucionalidade nº 4.190 MC/RJ. Relator: Min. Celso de Mello. Julgado em 01 de julho de 2009. Informativo STF no 553, jul./2009.

Disponível

em: <http://www.stf.jus.br/arquivo/informativo/documento/informativo553.htm>. Acesso em: 16 de abril de 2018.

. Superior Tribunal de Justiça. Recurso Especial $\mathbf{n}^{\mathbf{0}}$ 1.390.875/RS. Relator: Min. Napoleão Nunes Maia Filho. Julgado em 09 de junho de 2015. Disponível em: $<$ https://ww2.stj.jus.br/processo/pesquisa/?src=1.1.2\&aplicacao=processos.ea\&tipoPesquisa=t ipoPesquisaGenerica\&num_registro=201301933523>. Acesso em: 30 de setembro de 2018.

. Superior Tribunal de Justiça. Recurso Especial $\mathbf{n}^{\mathbf{0}}$ 1.657.156/RJ. Relator: Min. Benedito Gonçalves. Julgado em 25 de abril de 2018. Disponível em: $<$ https://ww2.stj.jus.br/processo/pesquisa/?termo=resp+1657156\&aplicacao=processos.ea\&ti poPesquisa $=$ tipoPesquisaGenerica\&chkordem $=$ DESC $\&$ chkMorto=MORTO $>$. Acesso em: 30 de setembro de 2018 .

BREGA, José Fernando. Governo eletrônico e Direito Administrativo. Brasília: Gazeta Jurídica, 2015.

BRESSER PEREIRA, Luiz Carlos. Reforma do Estado para cidadania: a reforma gerencial brasileira na perspectiva internacional. São Paulo: Editora 34; Brasília: ENAP, 1998.

. Reforma gerencial do Estado, teoria política e ensino da Administração Pública.

Revista Gestão \& Políticas Públicas, v. 1, n. 2, jan. 2012. Disponível em: <https://www.revistas.usp.br/rgpp/article/view/97836/96636>. Acesso em: 23 mar. 2018.

BUCCI, Maria Paula Dallari. Direito Administrativo e políticas públicas. São Paulo: Saraiva, 2002. 
BUSTAMANTE, Javier. Communicative power, digital ecosystems and digital citizenship. In: SILVEIRA, Sérgio Amadeu da (org.). Cidadania e redes digitais. São Paulo: Comitê Gestor da Internet no Brasil, 2010.

CARVAlho FILHO, José dos Santos. Manual de Direito Administrativo. 26. ed. São Paulo: Atlas, 2013.

CARVALHO. Matheus. Manual de Direito Administrativo. 4. ed. Salvador: JusPODIVM, 2017.

CASTELLS, Manuel. A Galáxia Internet: reflexões sobre internet, negócios e sociedade. Trad. Rita Espanha. 2. ed. Lisboa: Fundação Calouste Gulbenkian, 2007.

A Sociedade em Rede. Trad. Roneide Venancio Majer. 17. ed. São Paulo: Paz e Terra, 2016.

CARDOSO, Gustavo (orgs.). A Sociedade em Rede: do conhecimento à ação política. Conferência promovida pelo Presidente da República, 04 e 05 de março de 2005, Centro Cultural de Belém, Portugal, 2005. Disponível em: $<$ http://www.egov.ufsc.br/portal/conteudo/sociedade-em-rede-do-conhecimento-\%C3\%A0ac\%C3\%A7\%C3\%A3o-pol\%C3\%ADtica>. Acesso em: 19 de junho de 2018.

Communcation Power. Oxford: Oxford University Press, 2009.

CHIAVENATO, Idalberto. Introdução a Teoria Gral da Administração. 7. ed. Rio de Janeiro: Elsevier, 2003.

CONACI. Diretrizes para o Controle Interno no Setor Público. 2010. Disponível em: $<$ http://conaci.org.br/wpcontent/uploads/2012/05/DiretrizesparaControleInternonoSetorPublico.pdf>. Acesso em: 06 de abril de 2018.

CRUZ, Tadeu. Sistemas de informações gerenciais: tecnologias da informação e a empresa do século XXI. 2. ed. São Paulo: Atlas, 2000.

Sistemas, organização e métodos: estudo integrado das novas tecnologias de informação. 2. ed. São Paulo: Atlas, 1998.

DI PIETRO, Maria Sylvia Zanella. Direito Administrativo. 25. ed. São Paulo: Atlas, 2012.

FAGUNDES, Miguel Seabra. O controle dos atos administrativos pelo Poder Judiciário. 6. Ed. São Paulo: Saraiva, 1984. 
FAYOL, Henri. Administração Industrial e Geral: previsão, organização, comando, coordenação, controle. 10. ed. São Paulo: Atlas, 1989.

FERRARI, Regina Maria Macedo Nery. Controle Interno da Administração Pública e a aplicação de verbas na educação. In: FREITAS, Ney José de (coord.). In: FREITAS, Ney José de (coord.). Tribunais de Contas: aspectos polêmicos - estudos em homenagem ao conselheiro João Féder. Belo Horizonte: Fórum, 2009.

FERREIRA, Sergio de Andréa. Aspectos da autotela da Administração Pública. Revista de Direito Público, v. 15, 1971, apud DI PIETRO, Maria Sylvia Zanella; SUNDFELD, Carlos Ari (orgs). Controle da administração, processo administrativo e responsabilidade do Estado - Coleção doutrinas essenciais, v. 3. São Paulo: Revista dos Tribunais, 2012.

FRANÇA, Phillip Gil. O Controle da Administração Pública: combate à corrupção, discricionariedade administrativa e regulação econômica. 4. ed. São Paulo: Saraiva, 2016.

FRIEDMAN, Milton. Capitalismo e Liberdade. Trad. Afonso Celso da Cunha. Rio de Janeiro: LTC, 2014.

GOLDSMITH, Stephen; EGGERS, Willians D. Governar em Rede: O Novo Formato do Setor Público. Trad. Anja Kamp. Brasília: Fundação Editora da UNESP/ENAP, 2006.

GUERRA, Evandro Martins. Controle Sistêmico: a interação entre os controles interno, externo e social. Fórum de Contratação e Gestão Pública - FCGP, Belo Horizonte, ano 7, n.82, out. 2008. Disponível em: <http://www.bidforum.com.br/bid/PDI0006.aspx?pdiCntd=55275>. Acesso em: 31 out. 2016. GUSTIN, Miracy Barbosa de Sousa; DIAS, Maria Tereza Fonseca. (Re)pensando a pesquisa jurídica. 4. ed. Belo Horizonte: Del Rey, 2013.

HOBSBAWN, Eric. A Era do Capital: 1848 - 1875. Trad. Luciano Costa Neto. $21^{\text {a }}$ Ed. São Paulo: Paz e Terra, 2014.

KEEN, Peter G. W. Guia Gerencial para a Tecnologia da Informação: conceitos essenciais e terminologia para empresas e gerentes. Trad. Fernando Barcellos Ximenes. Rio de Janeiro: Campus, 1996.

LEMOS, André; LÉVY, Pierre. O Futuro da Internet: em direção a uma ciberdemocracia planetária. São Paulo: Paulus, 2010. 
MACHADO, Paulo Affonso Leme. Direito à informação e meio ambiente. São Paulo: Malheiros, 2006.

MARQUES NETO, Floriano; PALMA, Juliana Bonacorsi de. Os sete impasses do controle da administração no Brasil. In: PEREZ, Marcos Augusto; SOUZA, Rodrigo Pagani de. Controle da Administração Pública. Belo Horizonte: Fórum, 2017.

MARRARA, Thiago. Controle Interno da Administração Pública: suas facetas e seus inimigos. In: MARRARA, Thiago; GONZÁLES, Jorge Agudo (coord). Controles da Administração e Judicialização de Políticas Públicas. São Paulo: Almedina, 2016. p.45-65.

Direito Administrativo e novas tecnologias. Revista de Direito Administrativo RDA. Rio de Janeiro, v. 256, jan./abr. 2011. p. 225-251.

MAZZUCATO, Mariana. O Estado empreendedor: desmascarando o mito do setor público vs. setor privado. Trad. Elvira Serapicos. São Paulo: Portifolio-Penguin, 2014

MEDAUAR, Odete. Controle da Administração Pública. 3. ed. São Paulo: Revista dos Tribunais, 2014.

Direito Administrativo Moderno. 17. ed. São Paulo: Revista dos Tribunais, 2013.

MEIRELLES, Hely Lopes. Direito Administrativo Brasileiro. 34. ed. São Paulo: Malheiros, 2008.

MELlO, Celso Antônio Bandeira. Curso de Direito Administrativo. 30. ed. São Paulo: Malheiros, 2013.

MILESKI, Helio Saul. Tribunal de Contas: evolução, natureza, funções e perspectivas futuras. In: FREITAS, Ney José de (coord.). Tribunais de Contas: aspectos polêmicos - estudos em homenagem ao conselheiro João Féder. Belo Horizonte: Fórum, 2009. p. 89-115.

MORAES, Ricardo Quartim de. A evolução histórica do Estado Liberal ao Estado Democrático de Direito e sua relação com o constitucionalismo dirigente. Revista de informação legislativa, Brasília, v. 51, n. 204, p. 269-285, out./dez. 2014.

MOREIRA NETO, Diogo de Figueiredo. O Parlamento e a Sociedade como Destinatários do Trabalho dos Tribunais de Contas. In: SOUZA, Alfredo José de [et al.]. O novo Tribunal de Contas: órgão protetor dos direitos fundamentais. Belo Horizonte: Fórum, 2005. 
MOREIRA, Eduardo Ribeiro. A possibilidade de controle judicial das políticas públicas. In: FIGUEIREIDO, Marcelo (coord.). Novos rumos para o direito público: reflexões em homenagem à Professora Lúcia Valle Figueiredo. Belo Horizonte: Fórum, 2012. p. 159-173.

NOHARA, Irene Patrícia. Controle social da Administração Pública: mecanismos jurídicos de estímulo à dimensão sociopolítica da governança pública. In: MARRARA, Thiago; GONZÁLES, Jorge Agudo (coord). Controles da Administração e Judicialização de Políticas Públicas. São Paulo: Almedina, 2016.

O’BRIEN, James A. Sistemas de informação e as decisões gerenciais na era da Internet. Trad. Célio Knipel Moreira e Cid Knipel Moreira. 2. ed. São Paulo: Saraiva, 2004.

OLIVEIRA, Djalma de Pinho Rebouças. Sistemas, organizações e métodos: uma abordagem gerencial. 13. ed. São Paulo: Atlas, 2002.

PEDREIRA, Ana Maris. O Controle da Administração Pública como mecanismo para evitar a ocorrência de danos. In: MARQUES NETO, Floriano de Azevedo [et al.] (org.). Direito e Administração Pública: estudos em homenagem a Maria Sylvia Zanella Di Pietro. São Paulo: Atlas, 2013.

RAMOS JR, Helio Santiago; ROVER, Aires José. Perspectivas para a tele-administração no Brasil: sistemas inteligentes e software livre na Administração Pública. Anais Eletrônicos das $3^{\circ}$ Jornadas Argentinas de Informatica e Investigacion Operativa (JAIIO) Simposio argentino de informatica e direito, Mendoza, Argentina, 04-07 de set./2006. Disponível em: <http://www.egov.ufsc.br/portal/conteudo/perspectivas-para-teleadministração-no-brasil-sistemas-inteligentes-e-software-livre-na-ad>. Acesso em: 18 de maio de 2018.

RAWLS, John. Uma teoria da justiça. São Paulo: Martins Fontes, 2002.

REAL, Alberto Ramon. El control de la administracion. Revista de Direito Público, v. 32, 1974, apud DI PIETRO, Maria Sylvia Zanella; SUNDFELD, Carlos Ari (orgs). Controle da administração, processo administrativo e responsabilidade do Estado - Coleção doutrinas essenciais, v. 3. São Paulo: Revista dos Tribunais, 2012.

RIBEIRO, Renato Jorge Brown; BLIACHERIENE, Ana Carla; SANTANA, José Lima. Considerações sobre formas, processos e isoformismo nas estruturas de controle interno da Federação brasileira. In: BLIACHERIENE, Ana Carla; BRAGA, Marcos Vinicius de 
Azevedo; RIBEIRO, Renato Jorge Brown (coords). Controladoria no Setor Público. Belo Horizonte: Fórum, 2016.

RIO DE JANEIRO. Tribunal de Contas do Estado. Processo no 225.221-8/17. Disponível em:<https://www.tce.rj.gov.br/todas-noticias/-/asset_publisher/SPJsT15LTiyv/content/tcedetermina-que-toda-cidade-deve-ter-sua-procuradoria>. Acesso em 30 de setembro de 2018. RÜDIGER, Francisco. As teorias da cibercultura: perspectivas, questões e autores. 2. ed. Porto Alegre: Sulina, 2016.

SANTOS, Clezio Saldanha dos. Introdução à Gestão Pública. 2. ed. São Paulo: Saraiva, 2014.

SANTOS, Franklin Brasil; BRAGA, Marcus Vinicius de Azevedo. Do paradoxo à efetividade - a controladoria pública como instrumento de um estado mais eficiente e uma sociedade mais participativa. In: BLIACHERIENE, Ana Carla; BRAGA, Marcus Vinicius de Azevedo; RIBEIRO, Renato Jorge Brown (coords.). Controladoria no setor público. Belo Horizonte: Fórum, 2016, p. 37-60.

SANTOS, Marcelo Bidoia. Do Estado Virtual ao Estado Penal: transformações no Estado de Bem-Estar Social na Era da Informação. Dissertação (Mestrado em Direito) - Faculdade de Direito de Ribeirão Preto, Universidade de São Paulo, Ribeirão Preto, 2017.

SILVA, Arídio Gomes da; R, Luiz Alberto; RIBEIRO, José Araújo. Sistemas de informação na Administração Pública. Rio da Janeiro: Revan, 2004.

SILVA, José Afonso da Silva. Curso de Direito Constitucional Positivo. 25. ed. São Paulo: Malheiros, 2005.

O constitucionalismo brasileiro: evolução instuticional. São Paulo: Malheiros, 2011.

SILVA, Marco Aurélio de Barcelos. A "Lei da empatia": impactos do PL 7448/2017 sobre o controle externo da Administração Pública brasileira. Direito do Estado, 2018, n. 394. Disponível em: <http://www.direitodoestado.com.br/colunistas/marco-aurelio-de-barcelossilva/a-lei-da-empatia-impactos-do-pl-7448-2017-sobre-o-controle-externo-da-administracaopublica-brasileira>. Acesso em: 10 de maio de 2018.

SILVA, Virgílio Afonso. O judiciário e as políticas públicas: entre transformação social e obstáculo à realização dos direitos sociais. In: SOUZA NETO, Cláudio Pereira de; SARMENTO, Daniel. Direitos sociais: fundamentação, judicialização e direitos sociais em espécies, Rio de Janeiro: Lumen Juris, 2008. Disponível em: 
<https://constituicao.direito.usp.br/wp-content/uploads/2008-

Judiciario_e_politicas_publicas.pdf>. Acesso em: 20 de abril de 2018.

SIMÕES, Edson. Tribunais de Contas: Controle externo das contas públicas. São Paulo: Saraiva, 2014.

WEBSTER, Frank. Theories of the Information Society. 3. ed. New York: Routledge, 2006. 
Anexo I - Exemplo PALP ${ }^{34}$

\section{Reforma do prédio da sede do Intituto de Estudos Avançados - IEA}

2 Mapa de obras (https://palp.com.br/)

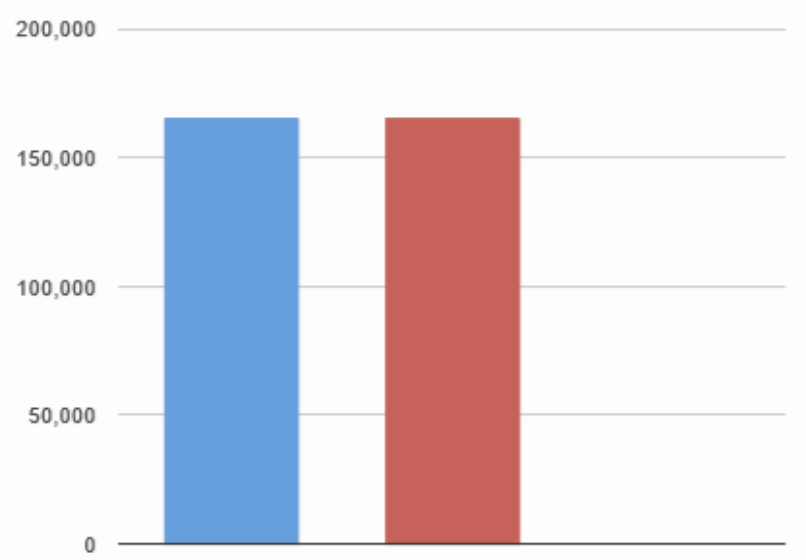

Valor Total: $\mathrm{R} \$ 165.401,66$

Valor Pago: R\$165.401,66

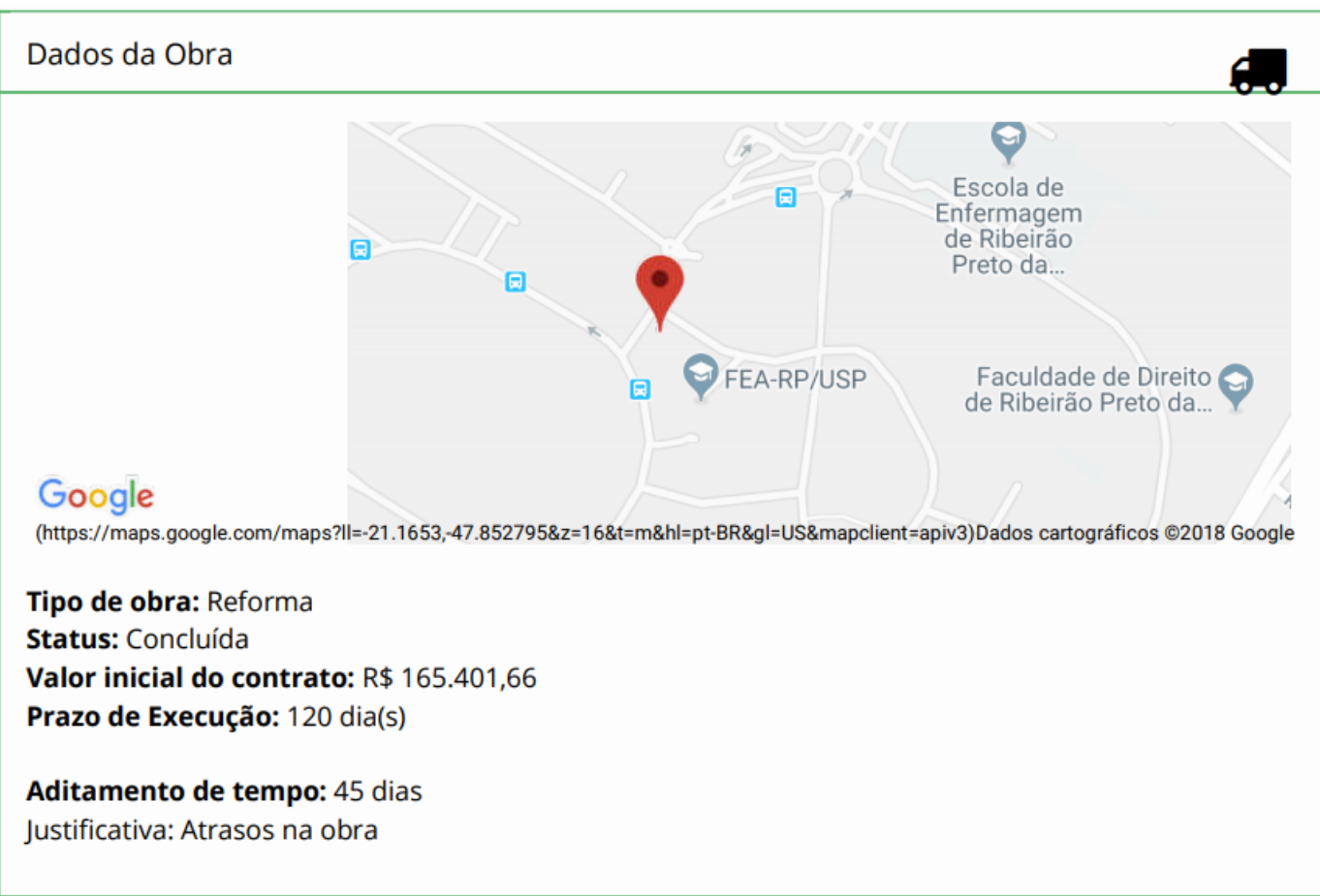

34 Imagens disponíveis em: <https://palp.com.br/obras/16/reforma-do-predio-da-sede-do-intituto-de-estudosavancados---iea>. Acesso em: 18 de junho de 2018. 
Especificações da Licitação

昼

Modalidade: Tomada de Preços

Orgão Executor: Superintendência do Espaço Físico da USP

Recursos: Não houve

Valor inicial estimado: $\mathrm{R} \$ 216.042,44$

Empresa participante $\quad$ Oferta

$\begin{array}{ll}1^{\circ} \text { Centro Construções } & \text { R } \$ 165.401,66\end{array}$

$\begin{array}{lll}2^{\circ} & \text { Ml Sanchez da Silva Construcoes - ME } & \text { R } \$ 171.385,51\end{array}$

$\begin{array}{lll}3^{\circ} \mathrm{Tj} \text { Construcoes e Terraplenagem } & \mathrm{R} \$ 174.601,22\end{array}$

Informações da Empresa

Nome da empresa: Centro Construções

CNPJ: 47.045.919/0001-65

Endereço: R Moreira de Oliveira, 112

Telefone: (16) 3620-7944 (tel:+55(16) 3620-7944)

Área de atuação: Outras obras de acabamento da construção

Participação nas últimas licitações (Últimos 12 meses): 1

Licitações vencidas: 1 